\title{
Should I stay or should I go? 6000 years of human presence and abandonments at Stromboli volcano and an overview on the whole Aeolian Archipelago (Southern Tyrrhenian Sea, Italy)
}

\author{
Andrea Di Renzoni ${ }^{1, *}$, Sara T. Levi ${ }^{2}$, Alberto Renzulli ${ }^{3}$, Mauro Rosi $^{4}$, David Yoon ${ }^{5}$ \\ (1) CNR, Institute of Heritage Science, Rome, Italy, andrea.direnzoni@cnr.it \\ (2) Department of Classical and Oriental Studies, Hunter College, City University of New York, NY, USA \\ (3) Dipartimento di Scienze Pure e Applicate, Università di Urbino, Urbino, Italy \\ (4) Dipartimento di Scienze della Terra, Università di Pisa, Pisa, Italy \\ (5) American Numismatic Society, New York, USA
}

Article history: received March 24, 2021; accepted October 22, 2021

\begin{abstract}
The paper addresses the long-lasting human presence on the island of Stromboli, an active volcano at the northern edge of the Aeolian archipelago, in the Southern Tyrrhenian sea, Italy. A conceptual model has been built to explore the phenomenon, it takes into account a series of aspects comparing Stromboli to other islands: their morphology, natural resources and geography along with the archaeological and historical data and, further, human attitude to volcanic environments, to risk and to insularity has been deeply explored. We propose a complex narrative where a combination of geological, socio-economic, historical, and psychological factors influenced people's choices and that human presence is related more to the volcanic (and island) environment (and opportunities) than to volcanic activity.
\end{abstract}

Keywords: Volcanic risk; Risk perception; Human volcano relationship; Archaeology; Long term history.

\section{Introduction}

The question posed in the title of this paper is quite clear but, perhaps, could be formulated in an even more direct way: why would anyone choose to live on a $12 \mathrm{~km}^{2}$ island on the slopes of an active volcano? Researchers have long considered human presence in hazardous areas [Kates, 1971; Burton et al., 2005] and volcanoes, among dangerous environments, have always attracted people, not only because of the potentiality they offer, but also due to the allure they exercise as all-providing, all-engulfing instruments of mighty power and as an object of awe. This has led the volcanological community to focus on the human dimension of volcanic activity [Gaillard and Dibben, 2008] and treating risk perception [Slovic, 2000; Kahneman et al., 1982; Gaillard and Dibben, 2008] as a central issue. 


\section{Andrea Di Renzoni et al.}

Thus, a human dimension perspective has been adopted to explore the long history of the interrelation between people and Stromboli, the northernmost of the seven islands (and some islets) that form the Aeolian Archipelago, in the Southern Tyrrhenian Sea. Stromboli is an active volcano, reaching the height of 924 meters a.s.l. It is located $70 \mathrm{~km}$ north of the Strait of Messina and only $50 \mathrm{~km}$ west of the coast of Calabria (Figure 1). Human presence on the island dates back at least to the $4^{\text {th }}$ millennium BCE, and, although with different population density through time, it is still inhabited today.

Although our paper focuses on Stromboli, to better understand the process that characterized its population history, the island has been analysed in the context of the whole archipelago. Stromboli has been compared to other islands in terms of physical characteristics, volcanic activity, and historical development. In the latter cases, only main events related to other islands have been addressed.

We propose that the combination of geological, socio-economic, historical, and psychological factors influenced people's choices and that volcanic (and island) environment, more than volcanic activity, is related to human presence.

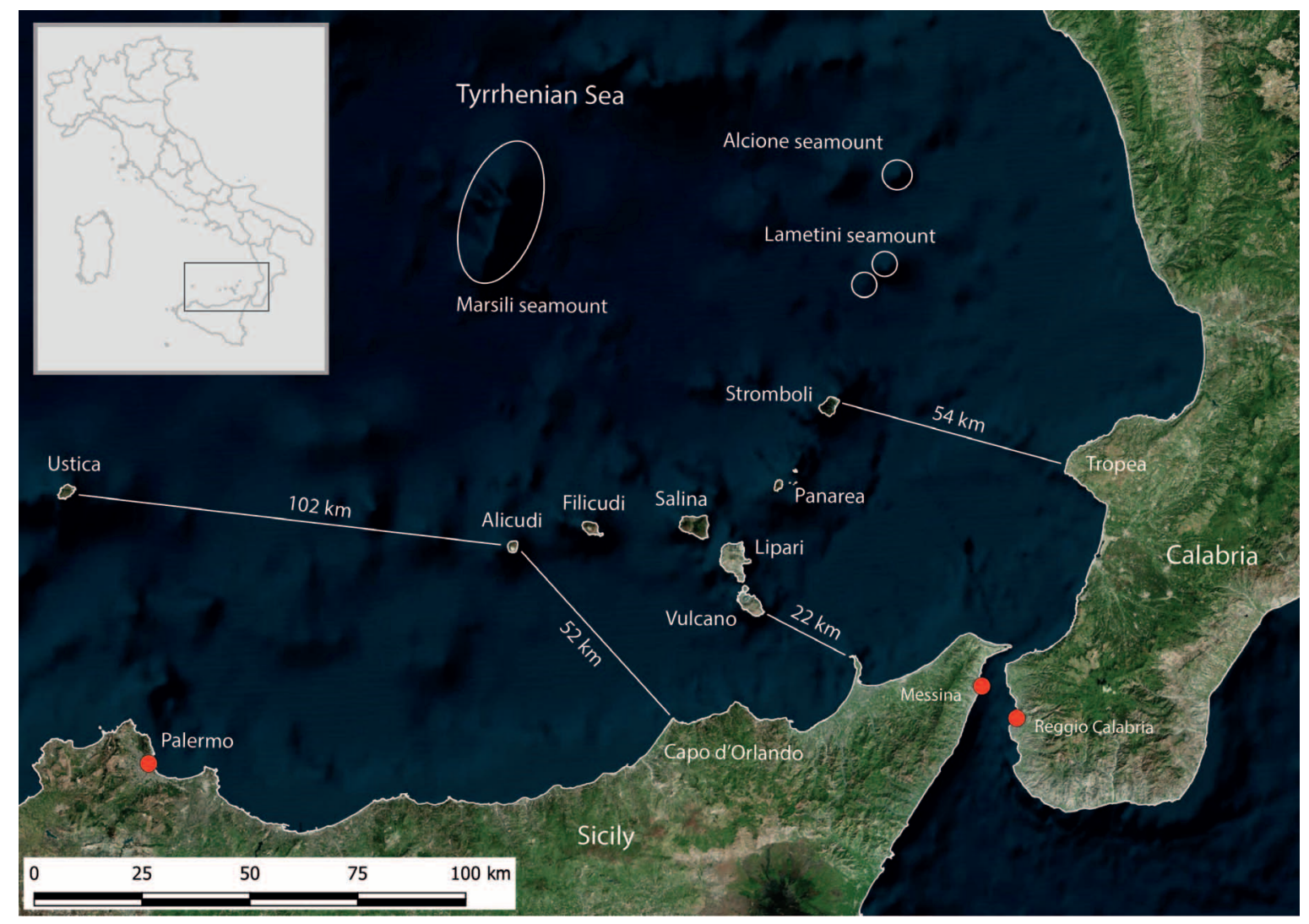

Figure 1. Aeolian Islands in the framework of the Southern Tyrrhenian sea.

\section{Materials and methods}

To tackle the issue of human-volcano interaction three main aspects of the matter have been deeply explored, seeking to avoid the (simplistic) equation according to which human presence in a volcanic environment is simply a function of volcanic activity. Indeed, it is believed that economic, social, and historical factors, as well as psychological attitudes intervene. Furthermore, it is not always easy to correlate volcanic events to demographic trends, mainly because of the chronological scale used and the data needed, a problem particularly true when ancient periods are addressed [Manni et al., 2019, p. 8]. The same general trends can be captured, but they must be read in the broader context in which phenomena developed. In the case of Stromboli, the reference framework chosen is the Archipelago, and the comparison among islands is the key to interpretation. 
The conceptual model we used works by employing dichotomies to describe the factors that pushed people to settle or to leave islands, that roughly correspond to the timing of the process and the scale of the social body affected:

1) Potentiality / danger. Every environment, technological improvement or, in a broader sense, change offers opportunity and generates threats. Balance is achieved when an individual or a society makes the maximum accepted effort to mitigate and therefore accept risk.

2) Factors that directly affect people / factors that indirectly affect people. Direct effects are those that have an immediate return on people's lives such as water scarcity; very often they are caused by rapid processes. As indirect effects are listed those that do not cause, or are perceived not to cause, a change in individuals' lives but they have a high capacity for triggering change. This dichotomy is closely related to the opposition between slow or long-term processes / rapid processes and events. Timing of a process has a strong influence on decision-making. An event is a process whose time scale can be equated (or perceived) to zero (a car accident, winning a lottery, a volcanic eruption). The bigger the time scale, the less the cause-effect relation is perceivable, and outcomes are embedded in daily routine.

3) Voluntary actions / involuntary actions. For a passive actor of an event or a process, the negative effects are more strongly perceived, while negative outcomes of voluntary actions are mitigated by psychological strategies people very often apply (see § 6.1).

4) Social constraints / individual needs. People act in a social context that influences their decision-making process, avoiding choices that would be seen as rational or, on the contrary, pushing to act rationally. Social constraints act at various levels, from family and community ties to institutional guidelines and laws.

Factors considered are related to physical characteristics, the complex relationship between humans and volcanoes, and the attitude people have toward risks:

A) Physical environment has been described as availability of resources (land, water and geology), accessibility (ease of landing on the islands), position of the islands (routes and visual landscapes).

B) The human-volcano system has been investigated in a wide geographical and chronological perspective, tying to gather recurrent attitudes towards volcanic environment that influence their perception.

C) Closely related to (B), attitude towards and perception of risk have been considered as a main element in the resolution of dichotomies (3) and (4).

Factors have been used to analyse human presence on the island of Stromboli during a long span of time, from late prehistory (late Neolithic/beginning of Copper Age, period of the first human traces on the island) to contemporary times. Presence and absence have been inferred from both archaeological and historical sources and have been put into the wider historical narrative of the archipelago. Demographic rate has not been systematically quantified but an evaluation, based on the archaeological remains and the literary sources [Barnao, 2017], has been proposed, also considering the comparison with other islands. History of volcanic activity has been traced and overlapped with the human presence history timeline. Interruptions of the human presence have been therefore compared with volcanic events or periods of more intense volcanic activity and, once the correlation has been noticed, other factors have been considered to evaluate the response people had to dramatic events.

\section{The context of the Aeolian Archipelago}

\subsection{The volcanism}

The seven islands of the Aeolian archipelago represent a volcanic arc and consist of the subaerial culminations of large, mainly submerged volcanic edifices rising 2000-2500 m above the Southern Tyrrhenian seafloor [Romagnoli et al., 2013]. Other submerged volcano edifices (seamounts) are represented by seven volcanic seamounts: Eolo, Enarete, Sisifo to the NW; Lametini, Alcione, Palinuro to the NE; and Marsili to the north. Aeolian volcanism is presently considered to develop in a subduction-type scenario with mantle-derived magmas belonging to the calcalkaline and alkaline (shoshonitic) series evolving their compositions through the crust during their uprising to the surface and then erupting as basaltic andesite, andesite, dacite and rhyolite [Lucchi et al., 2013a]. 


\section{Andrea Di Renzoni et al.}

The available radiometric ages [Lucchi et al., 2013a and references therein] for the subaerial activity of the whole Aeolian Islands shows that it mostly developed from ca 270-240 ka to the present, with Stromboli, Vulcano and Lipari being still active volcanoes. The oldest subaerial volcanic rocks are concentrated in the central-western sector of the Aeolian archipelago (Filicudi: 246-236 ka; Salina: 244-226 ka; Lipari: 267-188 ka), whereas the youngest phases of eruptive activity are focused in the central-eastern portions (Lipari: up to second half of $13^{\text {th }}$ century AD [Pistolesi et al., 2021]. Vulcano: up to 1888-90 AD eruption; Stromboli: persistently active). The major high-energy explosive eruptions (plinian type) took place during the past ca. $75 \mathrm{ka}$, characterized by the most evolved magmas (dacites to rhyolites): at Lipari (M. Guardia: 27-24 ka; Vallone del Gabellotto: 8.7-8.4 ka; M.Pilato: $8^{\text {th }}$ century AD; Forgia Vecchia, Lami and Rocche Rosse second half of 13th century AD [Pistolesi et al., 2021]. Stromboli (Petrazza: 77-75 ka) and Salina (Grey Porri Tuffs: ca 70-67 ka; Lower Pollara: $27.5 \mathrm{ka}$ ) and gave rise to widespread fallout tephra layers across the Aeolian archipelago [Lucchi et al., 2013b].

A few individual ages older than 270-240 ka which were reported for Filicudi [Santo et al., 1995] and Salina [Gillot, 1987] are now considered uncertain by the authors themselves, affected by high analytical error or not consistent with other more recent age constraints and stratigraphic relationships [Lucchi et al., 2013b]. By contrast submarine activity (seamounts) is assumed to have been developed entirely during the Quaternary, with the oldest submarine volcanic rocks located to the NW of the Aeolian archipelago (Sisifo seamount: 1.3-0.9 ka, Beccaluva et al. [1985]).

\subsection{Morphology of the islands}

Some of the evaluation made in this section is based on the recent morphology of the islands (only the 7 larger islands have been considered: Lipari, Salina, Vulcano, Stromboli, Filicudi, Alicudi and Panarea). During the considered span of time ( $6^{\text {th }}$ millennium BCE to present), some islands suffered dramatic volcanic events that deeply changed their shape. The morphology of Vulcano significantly changed in the last thousand years: the lava platform of Vulcanello emerged in medieval time, between $10^{\text {th }}$ and $11^{\text {th }}$ century AD [Arrighi et al., 2006; Malaguti et al., 2021]. The same occurred to a significant extent for the north-eastern sector of Lipari (i.e. eruptions of Monte Pilato at $776 \mathrm{AD}$ [Keller, 2002] and Rocche Rosse obsidian lava between 1250 and $1300 \mathrm{AD}$ [Tanguy et al., 2003; Pistolesi et al., 2021]). Stromboli had a significant morphological variation in the North Western part of the island where a sector collapse, shortly followed by a phreatomagmatic eruption ("Secche di Lazzaro" pyroclastics, Bertagnini and Landi [1986]; Renzulli and Santi [1997]), formed the so called "Sciara del Fuoco" horseshoe-shaped scarp as we can observe it nowadays. Significant morphological variations also occurred in the North Eastern sectors of Stromboli, as the result of the opening of the eccentric/lateral vent of San Bartolo and related lava flow during the GreekRoman Period (dated between 360 BCE and $7^{\text {th }}$ century AD through paleomagnetic method [Speranza et al., 2008]).

As eruptions at Panarea, Salina, Alicudi and Filicudi did not occur in the Holocene [Lucchi et al., 2013a and references therein] the morphology in these islands remained substantially unchanged from the $6^{\text {th }}$ millennium BCE to present, even if their shores might have been slightly altered by erosion. This aspect has to be taken into account when land availability and particularly accessibility to the islands are discussed. Data better describe the situation of the last centuries but, all the same, they can be used to propose generally valid evaluations.

\subsubsection{Land availability}

The islands of the archipelago differ in size from each other and, according to their surface, can be grouped in three clusters: 1) Lipari, the largest island, $37.5 \mathrm{~km}^{2}$ wide, followed by Salina $\left(26.2 \mathrm{~km}^{2}\right)$ and Vulcano $\left.\left(21 \mathrm{~km}^{2}\right) ; 2\right)$ Stromboli $\left(12.6 \mathrm{~km}^{2}\right)$ and Filicudi $\left(9.3 \mathrm{~km}^{2}\right)$; 3) Panarea $\left(3.4 \mathrm{~km}^{2}\right)$ and Alicudi $\left(5 \mathrm{~km}^{2}\right)$. The availability of land is an important factor for the subsistence of the population, especially during pre-modern periods when food production was a matter for each single community. Agricultural activities need land, the same is true for livestock; simply, a larger availability of land should correlate to the potentiality to sustain larger communities and, in our case, to a greater "appeal" of the single island.

The volcanic origin of the Aeolian Archipelago conferred on the islands their distinctive morphology, characterized by steep relief. Although terracing has been used to cultivate sloping surfaces, to evaluate the land potentiality, islands have been further classified according to the amount of flat or gently sloping surface. We used 
the slope tool of QGis ver. 3.12.1, an open-source GIS software; it generates a slope map from an elevation raster. TINITALY/01 DEM realized by INGV [Tarquini et al., 2007], freely available as a $10 \mathrm{~m}$ cell grid (http://tinitaly.pi.ingv.it/), has been chosen as elevation raster; the degree as the measurement unit of the slope. The algorithm produces a 32-bit floating raster that describes the continuous values of the steepness of the surfaces. The slope raster obtained was subsequently reclassified in a new raster, in which to each cell is assigned a value ranging from 1 to $3: 1$, corresponding to 0 to 15 degrees; 2, corresponding to 15.1 to 30 degrees; 3 , over 30 degrees (Figure 2). After the classification, cells of each island have been counted according to their value, and the area of the different kinds of surfaces has been estimated (Table 1).

\begin{tabular}{|c|c|c|c|c|c|c|c|c|}
\hline \multicolumn{9}{|c|}{ Sloping surfaces of the Aeolian Islands } \\
\hline \multirow[b]{2}{*}{ Island } & \multicolumn{5}{|c|}{$\mathbf{k m}^{2}$} & \multicolumn{3}{|c|}{ Percentage } \\
\hline & $0-15^{\circ}$ & $15-30^{\circ}$ & $0-30^{\circ}$ & $>30^{\circ}$ & tot & $0-15^{\circ}$ & $15-30^{\circ}$ & $>30^{\circ}$ \\
\hline Lipari & 13.33 & 14.84 & 28.17 & 9.49 & 37.66 & 35.41 & 39.40 & 25.19 \\
\hline Salina & 4.40 & 8.15 & 12.55 & 13.76 & 26.31 & 16.71 & 30.99 & 52.31 \\
\hline Vulcano & 9.21 & 7.13 & 16.34 & 4.86 & 21.20 & 43.47 & 33.62 & 22.91 \\
\hline Stromboli & 1.73 & 4.30 & 6.03 & 6.62 & 12.65 & 13.66 & 34.03 & 52.31 \\
\hline Filicudi & 1.19 & 2.47 & 3.66 & 5.70 & 9.36 & 12.68 & 26.40 & 60.91 \\
\hline Alicudi & 0.34 & 1.17 & 1.51 & 3.58 & 5.09 & 6.63 & 23.00 & 70.37 \\
\hline Panarea & 1.08 & 1.16 & 2.24 & 1.16 & 3.40 & 31.74 & 34.00 & 34.26 \\
\hline
\end{tabular}

Table 1. Different classes of sloping surface (in degrees) calculated at present-day, for the whole Aeolian Islands.

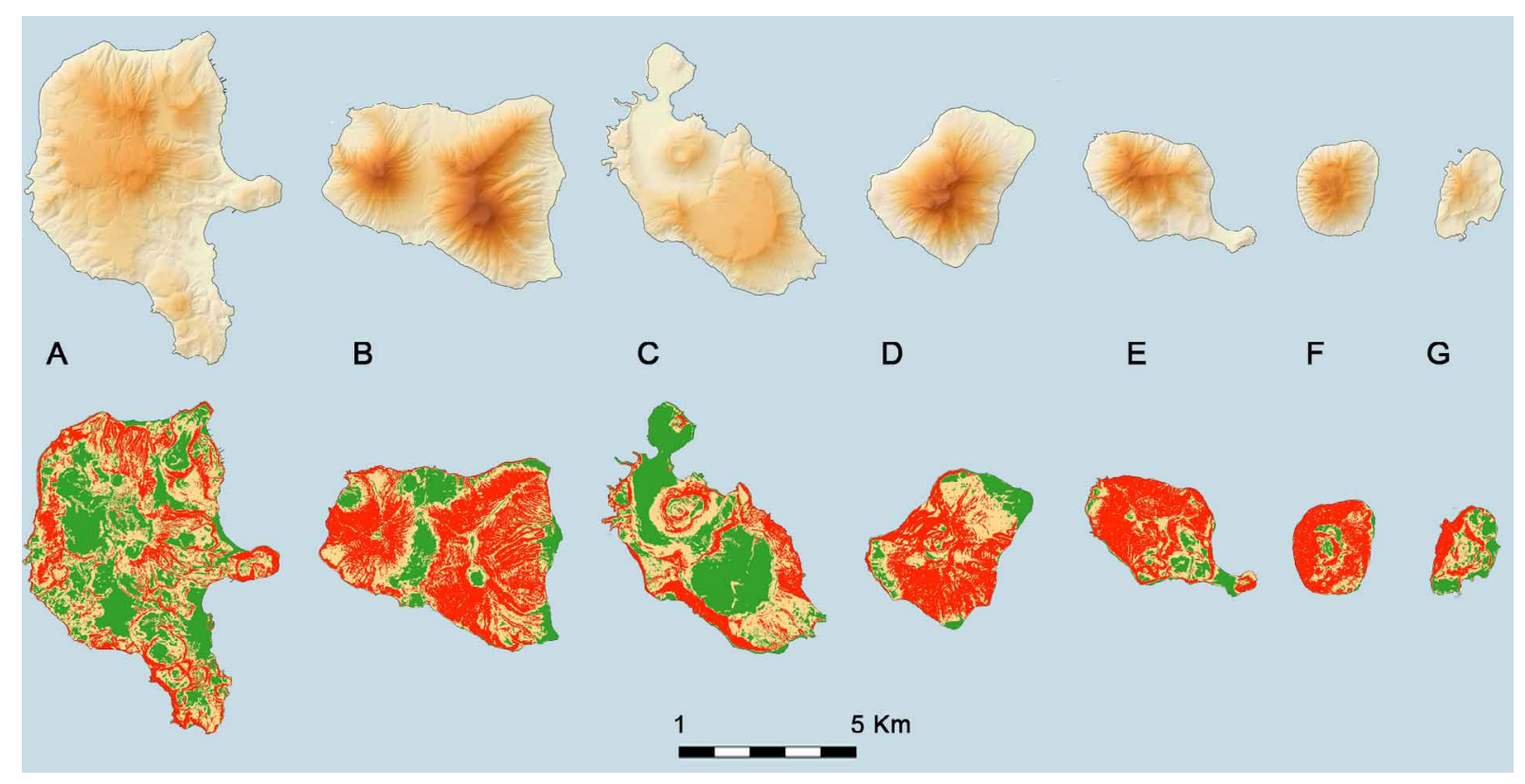

Figure 2. Morphology (top) and slope (bottom) maps of the islands. Slope colours are as follows: green: $0^{\circ}-15^{\circ}$; pale yellow $15^{\circ}-30^{\circ}$; red $>30^{\circ}$. A: Lipari; B: Salina; C: Vulcano; D: Stromboli; E: Filicudi; F: Alicudi; G: Panarea.

Four out of seven islands have more than $50 \%$ of very sloping surfaces $\left(>30^{\circ}\right)$ : Alicudi, Filicudi, Stromboli and Salina (ca 70\%, 61\%, 52\%, 52\% respectively); Panarea, Lipari and Vulcano are sensibly under that percentage (ca 34\%, $25 \%$ and 22\%). Those values, together with the others in Table 1, imply a different classification of the islands based on land availability: Lipari, with the largest amount (in $\mathrm{km}^{2}$ ) of flat land (FL, defined as the $0-15^{\circ}$ sloping surface, in square kilometres) stands in a separate group; Vulcano and Salina are in the second group, although Vulcano has 


\section{Andrea Di Renzoni et al.}

more than twice the $0-15^{\circ}$ sloping surface of Salina. It is however important noticing that much of the FL of Vulcano (Vulcanello and the Porto area) is likely younger than 1000 years. Stromboli is in the middle position for square kilometres $0-15^{\circ}$ of sloping surfaces, with $1.73 \mathrm{~km}^{2}$ of FL (14\% of the total surface); Filicudi, Panarea and Alicudi have a very low availability of FL (between 1.2 and $0.3 \mathrm{~km}^{2}$ ).

\subsubsection{Accessibility (ease of docking)}

Another attribute considered of great importance is the accessibility of the island. To evaluate the ease of landing, two main factors have been considered: the contour and the morphology (height and steepness) of the coast. These aspects were analysed by means of several GIS techniques. In addition to the INGV-DEM, a polygon shapefile provided by ISTAT (Italian National Statistical Institute) was used as numeric representation of the coast. Data format is ESRI shapefile, the reference system is WGS84 UTM 32N. The scale cannot be uniformly certified since the digitalization is based on different sources, mainly aerial photos and other cartography (https://www.istat.it/it/archivio/22252). A reduction of the vertex number of the polygons was necessary to avoid some unpredictable errors due to the high detail of the digitalization.

A general index of the sinuosity of the islands profile was calculated as the percentage of correspondence between the minimum bounding geometry (MBG), achieved using the bounding boxes geometry, and the actual shape of each island. A value close to 100 reflects a very smooth profile, a less degree of fitting reflects, on the contrary, irregularities of the coast. The MBG of Alicudi has a correspondence of $98.4 \%$ with the original shape of the island; Stromboli, Salina and Panarea show values around $90 \%$ (90.2, 90 and 89.1 respectively); Filicudi and Vulcano have values close to 80 per cent $(83.3,81.3)$ while Lipari has the less rounded profile, with a percentage of correspondence of 78.9 .

Another general index that describes the ease of landing is the average value of the heights and slope along the perimeter of the islands. Two single-side, 100- and 300-meter wide buffers of the coastline were obtained for each island. Subsequently, the overlapping of the buffer polygons with two raster datasets, the DTM and the slope map previously elaborated, was performed using the zonal statistic tool. The tool provides several statistics based on the raster cell values that fall in the buffer polygons; the mean value and maximum value were calculated for each island. The mean value of the height above sea level (MnHV) calculated for the 100 meter buffer divides the islands into two groups: Alicudi, Panarea, Filicudi and Salina around 40 meters (between 42.9 and 40.4) and Vulcano, Lipari and Stromboli around 35 meters (between 36.4 and 31,2). Values for the 300 meter buffer are slightly different: Alicudi has an MnHV of 108.1, Filicudi 93.8, Salina 80.4, Panarea and Stromboli around 78, Lipari and Vulcano around 72. Values of the slope indicates Alicudi and Filicudi as the steepest coasts (mean $=35.2^{\circ}$ and $32.5^{\circ}$ ), Lipari, Panarea, Salina and Stromboli around $27^{\circ}$ and Vulcano around $25^{\circ}$ (Table 2).

\begin{tabular}{|c|c|c|c|c|c|c|c|c|c|}
\hline \multicolumn{10}{|c|}{ Favourable landing points of the Aeolian Islands } \\
\hline \multirow[b]{2}{*}{ Island } & \multirow[b]{2}{*}{ MnHV } & \multicolumn{2}{|c|}{$100 \mathrm{~m}$ buffer } & \multicolumn{6}{|c|}{$300 \mathrm{~m}$ buffer } \\
\hline & & MxHV & MnSV & MxSV & MnHV & MxHV & MnSV & MxSV & SLPs \\
\hline Lipari & 34.60 & 194.41 & 28.59 & 78.54 & 72.81 & 284.79 & 25.17 & 78.54 & $5(2)[18]$ \\
\hline Salina & 41.90 & 284.42 & 27.87 & 83.17 & 80.43 & 411.40 & 26.01 & 83.17 & $4(2)[13]$ \\
\hline Vulcano & 36.34 & 166.01 & 25.23 & 77.38 & 72.04 & 345.17 & 23.70 & 77.38 & 7 (2) [16] \\
\hline Stromboli & 31.78 & 131.64 & 27.01 & 74.55 & 77.97 & 301.42 & 25.82 & 74.55 & $1(1)[3]$ \\
\hline Filicudi & 40.40 & 257.40 & 32.56 & 81.89 & 93.85 & 385.83 & 30.52 & 81.89 & 1 (3) [9] \\
\hline Panarea & 42.34 & 233.95 & 28.50 & 77.92 & 78.02 & 360.68 & 26.63 & 77.92 & $1(2)[5]$ \\
\hline Alicudi & 42.86 & 189.05 & 35.25 & 73.99 & 108.13 & 365.50 & 37.03 & 76.64 & 0 (1) [3] \\
\hline
\end{tabular}

Table 2. Classification of the ease of landing (docking). MnHV: average height value; MxHV: maximum height value; MnSV: average slope value; MxSV: maximum slope value; SLPs: suitable landing points, numbers in brackets refer to the SLPs according to a threshold of 40 meters, numbers in square brackets refer to SLPs placed where the mean height value above sea level excedes 40 meters. 
Further observations about the shape of the islands can be drawn by identifying inlets and headlands that correspond, in their digital representation, to strong direction changes of the perimetral lines; two methods were used to identify those points: inflection point detection (an inflection is a point on a continuous plane curve at which the curve changes from being concave to convex, or vice versa) and the comparison of the angle at vertex (bisector angle - VA) of each pair of the polyline vertices. Indeed, in the shapefile, polygons' perimeters are polylines, a sequence of points, the vertices, and segments connecting consecutive vertices, and (obviously) they are not continuous curves. First vertex coordinates and attributes (cf. VA) were extracted and a list of points coordinates obtained. Points were used as the dataset for an R script able to detect inflection points of the curve created by the spline interpolation of the same points. The algorithm computes the curvature along a dense set of intermediate points, identifies a range of near-zero curvature and marks the endpoints of those ranges. Endpoint coordinates are stored in a matrix and plotted on the map in the GIS framework. The second method used the same dataset of points, adding a new field to its attribute table, the absolute value of the differences between the VA of one vertex and the VA of the subsequent vertex. Results of the two methods are very similar and they identify the same section of coast, characterized by a sequence of little inlets and headlands.

Once the "favourable landing points" were identified, the heights above the sea level and the steepness of the coast corresponding to those points were evaluated. A 200 meter wide buffer was drawn around each point, and only the portions of the buffers falling on the island surface were considered to calculate the MnHV and the mean value of the slope (MnSV). The mean values were then assigned to each buffer, a threshold of 20 meters was applied to filter the most suitable landing points (SLPs; Table 2). Vulcano counts 7 SLPs, mainly on the north edge of the island, in the area of Vulcanello and 2 SLPs along the south coast (Gelso); Lipari has 4 SLPs, 2 of them close to the acropolis and the others on the north side of the island; Salina has 4 SLPs, 1 on the east coast (Santa Marina), 2 (very close one each other) on the south-eastern edge of the island (Lingua) and the last along the south coast (Rinella); the island of Panarea has 2 SLPs close to Punta Milazzese, on the south margin; the only SLP of Stromboli is on the northern side, in Ficogrande area; the same is for Filicudi, with a SLP on the south-eastern side of the island (Filobraccio); no SLP was found in Alicudi. Filtering the SLP with a bigger threshold of 40 meters above sea level does not significantly change the validity of the former observations. In Lipari there are 2 more SLPs on the west side; in Filicudi there are 4 more SLPs in the Filobraccio and Montagnola area and 1 on the west edge; in Stromboli 1 more SLP in Ginostra and 1 on Alicudi (Figure 3).

It is worth noting that the results of this analysis offer the chance of different interpretations. The comparison of the number of SLPs among the islands can be used as a ranking factor while their position is meaningful addressing the position of the islands in respect with the Southern Tyrrhenian Sea.

\subsection{Water sources}

Freshwater springs have always been scarce in the Aeolian Islands and their presence is attested almost exclusively at Lipari. On the islands, the need of water has always been a problem to face since antiquity, and rainwater collection has been the most adopted solution.

At the end of the $19^{\text {th }}$ century Luigi Salvatore of Austria published a series of eight books about the Aeolian Islands, describing the physical and anthropological aspects of the archipelago. His description of freshwater sources is precious, especially regarding the amount of water, since today the springs listed have a very limited flow rate [Mammana, 2006] and some of them are not recognizable anymore.

At Lipari known sources are concentrated west of Pianoconte, close to San Calogero thermal bath, along the west coast. In a stretch of land of about $1.5 \mathrm{~km}$ characterized by narrow valleys that run to the sea, three localities with water-sources are known. At "Valle dei Lacci", Luigi Salvatore of Austria mentioned four springs, one of them providing freshwater. This water-source is still active today with a flowrate not exceeding $2 \mathrm{l} / \mathrm{hr}$. South of "Valle dei Lacci” the water-source called "A Fonti Bruca” provided about $2 \mathrm{hl} / \mathrm{hr}$. In the locality "Fontanelle" two springs are known; they were used to water animals in the past century but today are abandoned; this locality was not mentioned by Luigi Salvatore of Austria. North of Pianoconte, in a locality called "Maduoru", ca $2.4 \mathrm{~km}$ from the coast, the author mentioned an important spring that offered a good quality of water, with a flowrate exceeding $1 \mathrm{hl} / \mathrm{hr}$. This spring was used at least until 1952, when the local administration restored the ancient cisterns utilized to collect water. 


\section{Andrea Di Renzoni et al.}

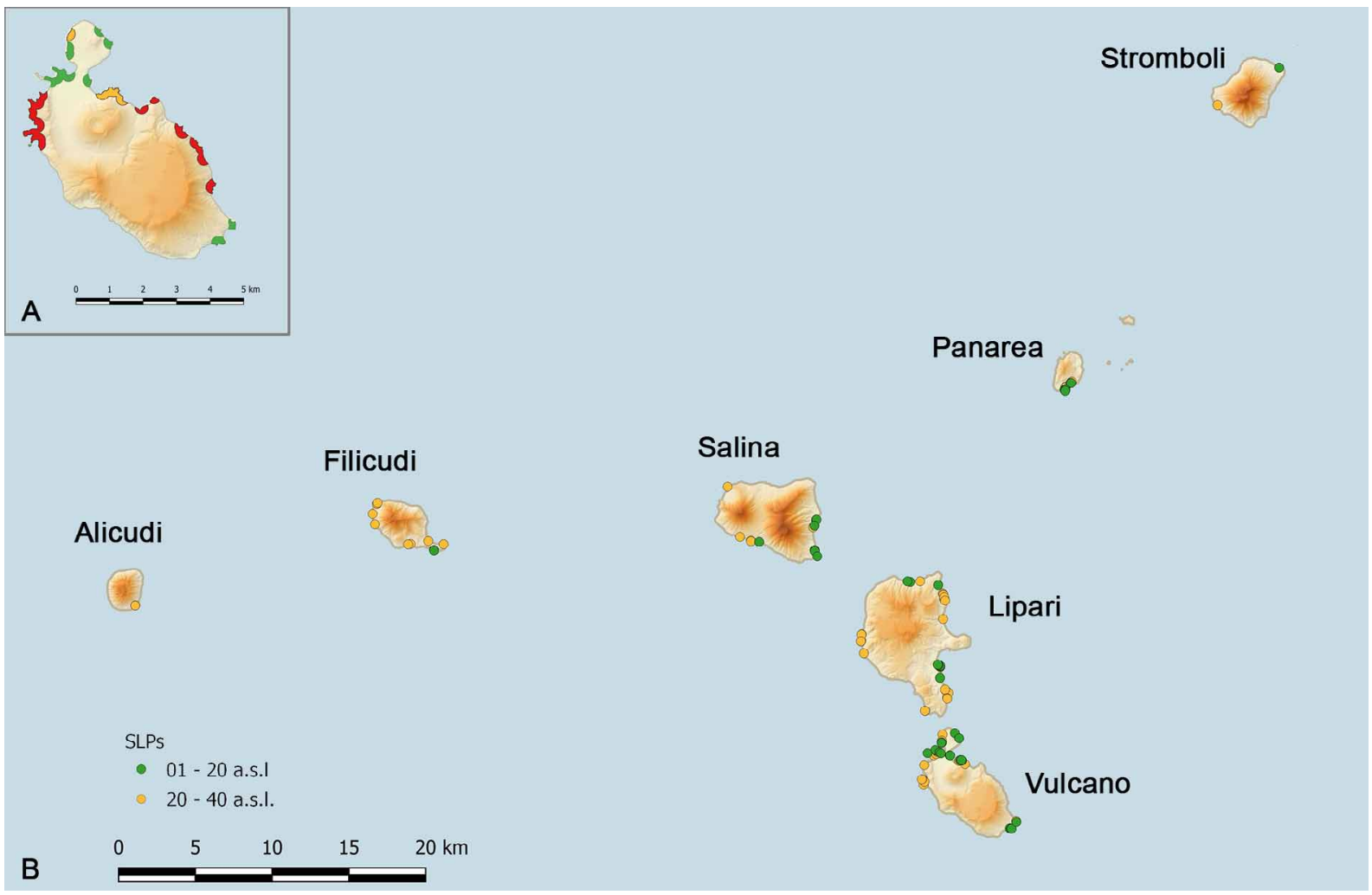

Figure 3. A) Map of Vulcano Island showing the SLPs (suitable landing points) found. Red dots are places where the coastline has a mean height value above sea level that exceeds 40 meters. B) SLPs found for the entire Aeolian Archipelago.

On the other islands there are no freshwater springs, and only few dripping points are known. At Salina, the "Fontana S. Onofrio", close to Pollara and the "U Puzzo" close to Malfa. This latter has been said to produce two barrels of good fresh water every $24 \mathrm{hr}$. At Filicudi, in the locality "Vallone Fontana” there is a dripping point called "Schicciola". The same name has been given to the dripping point of Vulcano, on the east coast of the island, and Stromboli where at least two dripping points are attested, the first in the locality called "Le Schicciole" on the eastern coast (at the top of the Forgia Vecchia slope, at an altitude of ca $400 \mathrm{~m}$ ), the second in the garden of a house near the modern harbour of Scari, called "Casa Schicciola”, eternalized in the book of Luigi Salvatore of Austria. The presence of a freshwater spring on the eastern slope of the volcano is also mentioned by several $18^{\text {th }}$ century explorers [Barnao, 2017].

Data regarding rainfall in the Aeolian Islands area are available for the period 1924-1994 and have been collected from the Regional Agency for Water and Waste (Osservatorio delle Acque, http://www.osservatorioacque.it/). It provides the daily amount of rainfall for the single meteorological station. Average total annual precipitation value over 70 years is $580 \mathrm{~mm}$ and monthly distribution is typical of the Mediterranean islands, with a dry semester from April to September. Fluctuations also occurred within periods, characterized by different amounts of precipitations as shown in the graph of Figure 4.

Rainfall collection had a long history in the Aeolian Island. In the Bronze Age village of Portella (Salina) a system of channels perpendicular to the slope, converging towards a single point has been found. During storms water is channelled to a single catch point. Many pithoi (large storage vessels) were found in the site; one of these, with the capacity of 500 litres, was buried below the floor of the hut Z [Martinelli, 2011]; it surely must have served as a cistern.

In recent times water collection was publicly administered to improve the efficiency of the water-system. In the $18^{\text {th }}$ century, for example, two large cisterns were built in Lipari, at “Contrada Diana”. Despite the efforts given by the community, the lack of water forced, at the beginning of the $20^{\text {th }}$ century, the municipality to import freshwater from outside the archipelago. In recent years the islands are supplied by a water tanker on a regular basis; a national 
law of 1950 (modified in 1967) ratified that the Italian State oversees the water supply of the minor islands, among which the Aeolian Islands are listed. Water remains a problem still today, and despite the construction of a desalinization plant, rainfall collecting is still a suggested solution [Campisano et al., 2017].

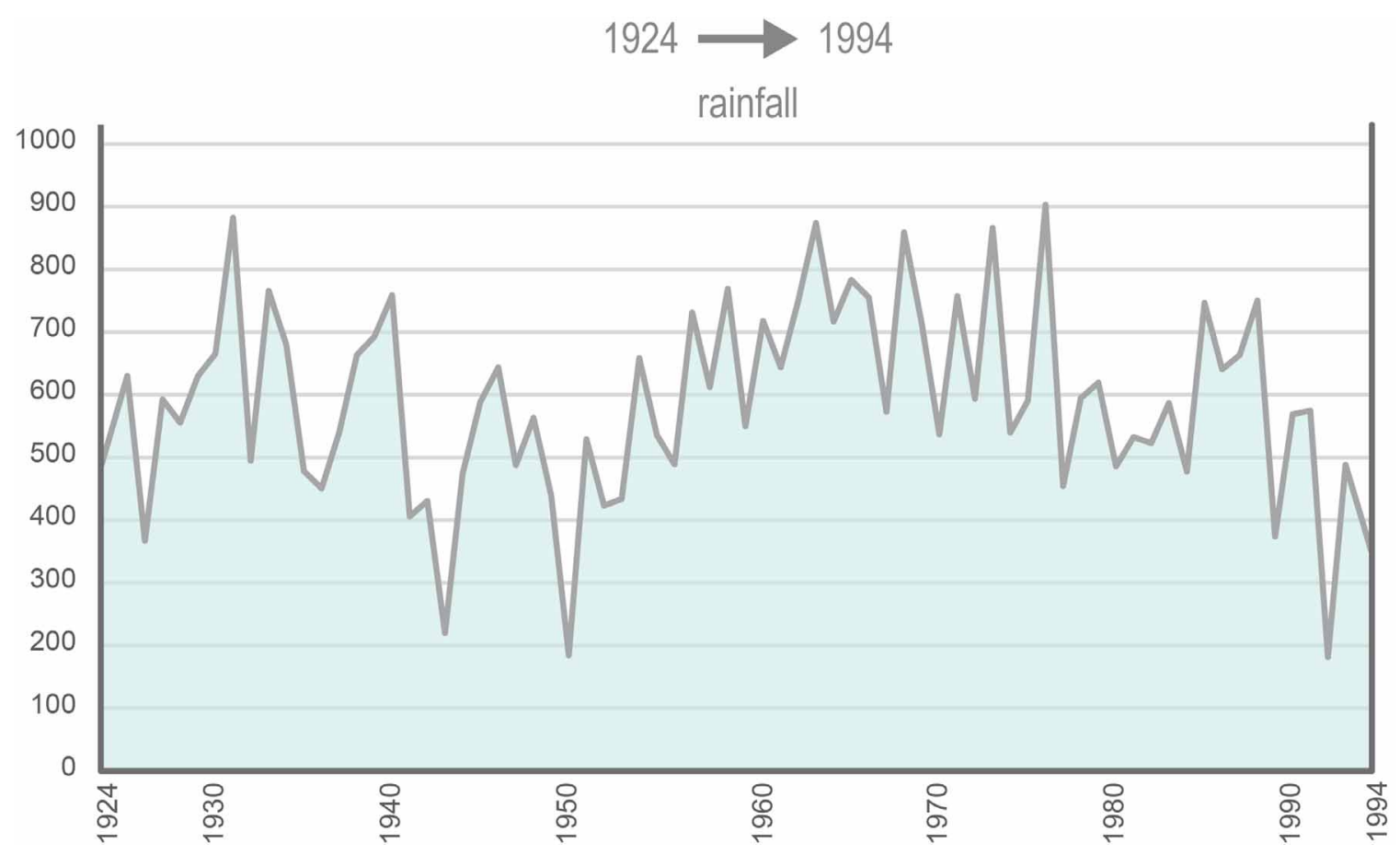

Figure 4. Graph showing the rainfall rate from 1924 to 1994 in the Aeolian Archipelago. Data have been collected from the Regional Agency for Water and Waste (Osservatorio delle Acque, http://www.osservatorioacque.it/).

\subsection{Geological resources}

The various products of volcanic activity were in great demand for both manufacturing and medicinal purposes in the ancient world, as they are today. Volcanic rocks were often chosen as stone tools, as materials for building and sculpture, as millstones, as additives to make cements that set under water; some minerals were used to prepare medicinal, cosmetics, pigments and for the treatment of leathers and textiles; geothermal fluids attracted people for their curative properties and are still used for energy production.

\subsubsection{Volcanic rocks}

\section{Lavas}

Lavas, in particular those of basaltic composition with their rough surface due to the presence of $\mathrm{cm}$-seized vesicles, have a good grinding capacity and for that reason were largely used as millstones since the Late Palaeolithic [Santi et al., 2021 this volume]. Several studies testify how grinding-stones were exported from volcanic areas to faraway places and, furthermore, imported millstones were found in volcanic contexts. In the central Mediterranean, as an example, millstones from Pantelleria had a wide distribution. Basaltic millstones from this island have been found in a Phoenician shipwreck dating to the $7^{\text {th }}$ century BC, sunk in the Xlendi Bay in Gozo (Maltese Islands) [Renzulli et al., 2019]. Almost all the grinding stones found in the shipwreck of El Sec (Mallorca), dated to the $4^{\text {th }}$ century BCE, had the same provenance from Pantelleria [Williams-Thorpe and Thorpe, 1990] with the exception of 


\section{Andrea Di Renzoni et al.}

one millstone coming from the Island of Nisyros (Greece) and another from Mulargia (Sardinia). An archaeometric study of some lava millstones from the island of Ustica revealed that, although most of them were made from local rock, some manufacts for grinding cereals were imported from Pantelleria and the Hyblean Mountains and a few, probably in modern times, from the Aeolian Islands [Santi et al., 2020]. Although the diffusion of Aeolian grinding stones seems to have been limited [Santi et al., 2013], in southern Italy and mainly Sicily, Greek and Roman period millstones from the Archipelago are attested in several sites like Messina [Di Bella et al., 2016], Selinunte [Gluhak and Schwall, 2015], Entella [Daniele, 2012] and Morgantina [Santi et al., 2015]. Clearly, lavas are ubiquitous in the Aeolian Archipelago and though some authors state that a clear distinction among single islands [Gluhak and Schwall, 2015] is difficult, others indicate Vulcano and Lipari as the most suitable source of the materials used [Di Bella et al., 2016; Santi et al., 2013]. Ancient millstone quarries of the cordierite-bearing andesite lava (with garnet and sillimanite xenoscrysts as well) of the Pulera Formation [Tranne et al., 2002] are known in the Fossa del Fuardo area - Lipari, and along the west coast of the island [Martinelli, 2015].

\section{Obsidian}

Obsidian is a wholly, or almost wholly, vesicle-free, $\mathrm{SiO}_{2}$-rich, glassy volcanic material. Obsidian blocks occur either in the outer part of lava flows or within pyroclastic deposits. Because of its excellent flaking quality, it has been used for millennia to produce extremely sharp cutting edges. Obsidian tools have been found over considerable distances from the source. Lipari is particularly rich in obsidian deposits [Bernabò Brea and Cavalier, 1960; Martinelli et al., 2020]. Ancient sources are 1) at the south edge of the island, where the obsidian rich lava domes o of S. Lazzaro, M. Guardia and M. Giardina are dated immediately after 27-24 Kyr [Lucchi, 2009; Forni et al., 2013]; on the east coast, where the most ancient obsidian rich formation is 2) Vallone Canneto dentro, recognized above the older layers of the Upper Brown Tuffs (24-20 ka) from Vulcano, and covered by the formations of Monte Gabellotto Monte Pilato, whose marker bed dates to 8.7-8.4 kyr [Zanchetta et al., 2011; Forni et al., 2013] and whose upper unit is the 3) obsidian-rich lobate coulee of the Pomiciazzo Formation, dated most probably to 8.6 ka [Wagner et al., 1976; Arias et al., 1986; Forni et al., 2013 p. 247]. In most recent times, an obsidian lava was emitted during the eruption of Monte Pilato (also producing a pumice cone and a widespread tephra layer towards north-east) during the $8^{\text {th }}$ century AD [Pistolesi et al., 2021]. In the north-eastern sectors of Lipari the activity resumed in the second half of the $13^{\text {th }}$ century AD with the explosive eruption of Forgia Vecchia that culminated in the emission of a bilobate obsidian lava flow [Pistolesi et al., 2021]. This was shortly followed by the explosive eruptions of Lami and Rocche Rosse. the latter ended with the homonimous obsidian lava flow [Pistolesi et al., 2021].

Obsidian from Lipari had a wide distribution, being found at over 200 archaeological sites throughout Sicily, mainland Italy, southern France, northern Africa and Dalmatia [Freund, 2018; Forenbaher 2018]. Exploitation of this raw material could have been the trigger of a stable occupation of the island, dated back to the Stentinello period ( $6^{\text {th }}$ millennium BCE) although the moment of greatest exploitation of obsidian is in the late Neolithic, during the Diana period (second half of $5^{\text {th }}$ millennium BCE) when a big village occupied the locality of the same name, corresponding to the centre of the modern town of Lipari (Martinelli et al. 2019). Obsidian is also attested on Vulcano Island, in the sequence of Grotta dei Palizzi 2.2-2.1 kyr and from the outcrop of Pietre Cotte, dated to the 1700s AD [De Astis et al., 2013; Tykot et al., 2019].

\section{Pumice}

Pumice is a pyroclastic rock consisting of highly vesicular rough textured volcanic glass. It has a high porosity (up to 85 vol. \%) and generally it floats on water. It has been used since antiquity for various purposes, such as building activities, medicine, cosmetics and as a sharpening stone. Several authors wrote about properties of pumices, among others Theophrastus, Dioscorides and Pliny the Elder, the latter of whom firmly attested that the best pumice comes from Melos, Nisyros, and the Aeolian islands [Pittinger, 1975]. Pumice is very abundant in the north-eastern part of Lipari and has been a fundamental economic resource for a long period. An ancient attestation of trade in pumice is from a cemetery of the Sedment village (Egypt), perhaps Tomb 421, dubiously attributed to the $18^{\text {th }}$ dynasty $\left(16^{\text {th }}\right.$ century BCE). It has been excluded that the pumice had been transported by sea but, rather, the presence of the Liparian material has been thought to be related to Mycenaean traders [Sterba et al., 2009], whose presence is well attested in the Archipelago (see § 3.5.2). Another proof of ancient trade in pumice is from the site of Tel Megadim, on the cost of Israel, where a pumice from Lipari has been found in a level dated to $6^{\text {th }}-3^{\text {rd }}$ century BCE [Steinhauser et al., 2006]. 
The first historical mention of trade in Liparian pumice dates to $1276 \mathrm{AD}$, when Charles of Anjou authorized the bishop to export the volcanic rock. In $1781 \mathrm{AD}$ Déodat de Dolomieu, writing about his journey in the Aeolian Islands, stated that Lipari provided pumice to all of Europe, while a proper industrial exploitation of Liparian quarries begun only in $19^{\text {th }}$ century (and ceased in 2007). The importance of such industry becomes clear comparing the amount of pumice quarried in Lipari through time: the quantity of quarried and exported material grew from 500 tons in the mid- $17^{\text {th }}$ century to 600,000 tons in 1972 [Giacomantonio, 2010].

\subsubsection{Minerals}

\section{Sulphur}

Deposits of native sulphur are largely present at the vents of high temperature fumaroles of active volcanic crater areas. Sulphur is also present in combination with other elements in rocks and minerals, from which it can be extracted. Its properties and applications were well known in ancient times. Egyptians used sulphur to bleach cotton, Greeks and Romans utilized it as an antiseptic and topical pharmaceutical, while the Chinese used sulphur in explosives. Sulphur's characteristics were described by several authors such as Theophrastus and Pliny the Elder who enhanced the pharmacological application of the substance. Sulphur is mentioned also in The Odyssey when Odysseus asks for the substance to purify his palace after the slaughter of the Suitors. Today sulphur is used in a wide range of industrial processes.

Before the modern procedures to extract sulphur from sulphates, it was collected from fumarolic areas or obtained by heating rocks containing sulphur. The Aeolian Islands are rich in both sources of sulphur; fumaroles are in Panarea, Lipari and Vulcano. Indeed, ancient historians indicated Melos and Lipari as the main sources of sulphur and alum in the Mediterranean, though it is possible that Aeolian sulphur was exploited from Vulcano, considered a territory of Lipari, given the islands' proximity [Photos-Jones et al. 2017, p. 306]. The mining industry on Vulcano had a long history and great importance. In 1813 Vito Nunziante had the license for extracting and purifying sulphur and therefore installed a factory on the island [Giacomantonio, 2010 p. 283]. Nunziante's mining company was then bought by the Scots industrialist Stevenson in the late $19^{\text {th }}$ century and, at the beginning of $20^{\text {th }}$ century, mining rights were sold to the Conti family of Lipari [Photos-Jones et al., 2017 p. 303]. The sulphur extraction industry was still active during the last eruption (1888-1890).

\section{Alum}

As with sulphur, the properties of alumen were widely described by classical authors such as Pliny the Elder. It served various purposes in mineral processing, it was used as mordant for fixing dye and it had countless medical applications. Probably the ancient term referred to several distinct minerals, which were principally sulphates, including potash alum [Photo-Jones and Hall, 2014 ], though it has been translated in modern language as alum (hydrous potassium aluminium sulphate [Photo-Jones and Hall, 2014] and very often it had been identified with alunite (hydroxylated aluminium potassium sulphate) or alum stone. Minerals that can be listed as alumen are astringent, and the term probably referred mainly to this property [Pittinger, 1975].

Alum-group minerals often derive from volcanic rocks rich in potassium (trachyte and rhyolite) and, according to Pliny the Elder reporting about Melian alum, alumen could be obtained from two main sources: rocks containing alunite and as efflorescence from fumarolic alum. The former source would have required a prolongated heating at high temperature, the latter would have been harvested [Photo-Jones and Hall, 2014].

Alumen had a huge economic significance at least since the Bronze Age, as some archaeological sources testify. Two Linear B tablets from Pylos record exchange of an unspecified amount of alum for various commodities. Other Mycenaean tablets mentioning alum are from Tiryns and Knossos. The beginning of Mycenaean presence in Italy is dated to, at least, Late Helladic I $\left(17^{\text {th }} / 16^{\text {th }}\right.$ century BCE). Aegean pottery of this period has been found in the Aeolian Archipelago (Lipari, Filicudi and Stromboli) and on the island of Vivara, in the Gulf of Naples. Some authors state that exploitation of the minerals found in the volcanic landscapes in the Southern Tyrrhenian sea, once discovered by Aegean voyagers, was the foremost purpose of the establishment of the route through the Strait of Messina [Photos-Jones and Jones, 2018]. During Roman times the alum trade involved a wide network across the Mediterranean. According to Diodorus of Sicily, Lipari, thanks to its famous alum mines, held the monopoly of the valued substance, further available only on the island of Melos. Pliny the Elder wrote that alum occurred, among 


\section{Andrea Di Renzoni et al.}

other places, on Stromboli and Lipari, although the best quality was the Egyptian and Melian alum. Archaeological evidence also attests the significance of the alum trade: Lipari has been identified as the production locus of the Richborough 527 amphorae, thought to be a container for alum. This kind of amphora had a wide distribution in the western Mediterranean and reached the Adriatic and Britain [Scheidel, 2012]. The precise identification of the mineral provenance is not simple. As stated, ancient authors most of the time used the name Lipari to refer to the whole archipelago [Mosconi, 2002] and, although Stromboli is the only other island of the archipelago mentioned, material evidence and historical documents indicate Vulcano as the main source of alum. In $1247 \mathrm{AD}$ alum of Vulcano was mentioned in a diploma of Emperor Frederick II; in 1276 AD the bishop of Lipari and Patti asked authorization for the extraction of sulphur and alum from Vulcano [Mosconi, 2002] while, the same as for sulphur, industrial exploitation begun in 1813. A recent enquiry on the Stevenson venture in Vulcano confirmed the presence of the veritable range of alum group minerals found within the so called "cave of alum" thought to be the main source until the $19^{\text {th }}-20^{\text {th }}$ century.

\section{Kaolin}

Although the mineral was surely used in antiquity, the word "kaolin" has a recent origin. It comes from the Chinese word Gaoling, referring to the region of its discovery, in the $17^{\text {th }}$ century. The term can be defined as a group name that includes kaolinite and some almost identical minerals [Photos-Jones and Hall, 2014]. A large deposit of kaolin is on the west coast of Lipari, at Quattropani, giving the name of "Cave di Caolino" (kaolin quarries) to the place. Liparian kaolin was exploited at least from the end of the $4^{\text {th }}-3^{\text {rd }}$ century BCE, when it was employed for making pots and, in addition, amphora sherds of the same period have been collected in the cave, testifying to the dating of the oldest known quarry activity.

Modern exploitation of the resource involved some of the most important Italian firms in the production of building material and lasted until 1972 [Martinelli, 2015].

\subsubsection{Geothermal activity}

Geothermal activities, with their astonishing manifestations, have always had a great allure for mankind. Not only geyser and hydrothermal explosions, but also fumaroles and hot steaming ground, hot springs (both on- and off-shore) and hot lakes, are strong landmarks and, special in antiquity, have often been considered the manifestation of chthonic forces or deities, at times evil and punitive, at others benevolent to people. Probably the most evident materialization of the relationship between mankind and geothermics is the use of thermal water for healing, strongly linked to the religious sphere [Croon, 1967; Griffith, 2015]. Roman baths are an eloquent example of the phenomenon, although it should be noticed that cults related to thermal water date well before the Roman period. In the provinces of the Empire, Romans assimilated and transformed local cults and deities associated with natural water sources [Griffith, 2015]. The malevolent side of geothermal was epitomized by deities to be placated and whose ill effects were to be warded off. Mefitis, as an example, was a divine personification of the Oscan word for the suffocating sulphurous gas from volcanic emissions; her cult was diffuse in southern Italy and Sicily, and it is argued that, at least in some cases, its sanctuaries were dedicated to healing cult utilizing the sulphurous waters [Griffith, 2015; Edlund-Berry, 2006].

Secularization of the relationship between mankind and thermal water started during the Roman period and although developed as a business activity during later times, the cultural significance of the geothermal manifestations did not diminish. The word "spa", deriving from the Belgian place Spa, has been subsequently related to the Latin locution "salus per aquam or sanitas per aquam" to underline the curative properties of geothermal water. It recently gained new connotations, in $19^{\text {th }}$ century Europe, "spa" was also a social and cultural centre, frequented by noble and rich people [Kepinska, 2004]. Today, more than the curative functions, cultural, social and phenomenological aspects [Heimisdóttir et al., 2019] are predominant, and geothermal phenomena has become a tourist attraction and an important economic source.

\section{Fumaroles and gas emissions}

Fumaroles, as stated, can provide sulphur and alum, and their heat is believed to be curative, but they have also a highly imaginative power, stimulating different feelings: fascination, awe, and fear. At Panarea, in the 
northernmost part of the island, the name Calcara indicates a semi-circular hollow basin, probably the remain of an ancient crater eroded by weathering. The bottom of the basin is almost completely isolated from the surrounding areas, it is difficult to reach and hosts a broad fumarolic field that extends beyond the coastline. Despite these disadvantageous characteristics, human presence at Calcara had a long history. Archaeological excavation carried out in 1947-48 indicates three periods of human activity, the first during late Neolithic (Diana facies, $5^{\text {th }}$ millennium $\mathrm{BCE}$ ), the second during the Bronze Age (Capo Graziano facies, late $3^{\text {rd }}$ millennium BCE), the third during the classical period (end of $4^{\text {th }}-2^{\text {nd }}$ centuries BCE). Bronze Age layers revealed unusual feauters, little wells reaching the depth of ca 1 meter, encased by marine pebbles, that have been defined as bothroi by L. Bernabò Brea and M. Cavalier. Their function remains unknown though it is likely they were used to receive offerings for endogenous forces or chthonian deities [Bernabò Brea and Cavalier, 1968, pp. 7-19]. In addition to Calcara, fumarole fields characterize the seabed of Panarea and the surrounding outcrops [Spagnoli et al., 2020].

Fumaroles are found in Lipari, close to the "Cave di Caolino" at Bagno Secco and at Vulcano. In this latter island, fumaroles exist within the Fossa crater, Vulcanello crater (up to $1^{\text {th }}$ century) as well as close to the Faraglione. There, fumaroles were exploited as a sulphur source before the $1^{\text {th }}$ century [Photo-Jones, 2017 p. 321], while more recently they are part of the "mud pool" thermal bath, an important tourism attraction for the island and for the whole archipelago.

\section{Hot springs and thermal water}

Thermal springs, in comparison with freshwater, are numerous in the Aeolian Islands: six springs are known on Lipari, two on Panarea and Vulcano, one on Salina and on the Bottaro islet, in front of Panarea [Mammana, 2006].

There is a concentration of thermal springs on the western side of Lipari: "San Calogero - Bagno" (temp. $40^{\circ}$ $50^{\circ}$ flow rate of $7-8 \mathrm{l} / \mathrm{min}$ ); "Bagno Secco" (temp. $40^{\circ}-50^{\circ}$, flow rate of ca $10 \mathrm{l} / \mathrm{m}$ ); "Valle del Fuardo"; "Valle dei Lacci". On the opposite side two springs are known: "Vagnamari" (temp $42^{\circ}$, flow rate ca $21 / \mathrm{m}$ ) and "Pignataro". Thermal water and geothermal activity in Lipari have been exploited for healing purposes since antiquity. Diodorus of Sicily praised their curative properties, renowned outside the Archipelago and attracting people from Sicily, and several ancient thermae are known: "Terme di San Calogero" has been active for centuries, probably from the Bronze Age, when an Aegean-type tholos was built as a thermal stove, until 1975; "L'Organo di Eolo" in locality "Piano Greca", dated to the $4^{\text {th }}$ century AD; Contrada Diana, at the periphery of the roman town, dated to $2^{\text {nd }}$ century CE; "Terme di Via Franza", a little thermae dated probably to the $4^{\text {th }}$ century BCE [Martinelli, 2015].

At Panarea thermal water of "Drauto" and San Pietro were used for the treatment of skin diseases; today they are not recognizable. At Vulcano, near the "Forgia Vecchia" flowed the water of "Acqua del Bagno" (temp. $55^{\circ}$, flow rate $0.5 \mathrm{l} / \mathrm{m}$ ) and on the east coast, between "Capu Riddu" and "Punta Luccia" another hot spring was known; today the hot springs of Vulcano are not recognizable. Also the spring depicted in Salina, at Malfa (locality "Pertuso") is today not recognizable.

\subsection{Position in the framework of the Southern Tyrrhenian Sea}

As stated, the position of the Aeolian Archipelago is on the important route that goes from the eastern Mediterranean to the Tyrrhenian Sea through the Messina Strait. The position of the single islands in the larger framework of the Southern Tyrrhenian Sea might have been an important factor acting, in certain periods, on their development. Furthermore, the "visual landscape" of each island, which strongly depends on its placement and on the location of its villages, contributes to shaping the cultural identity of communities and influences the way in which islands participate in specific networks. Some examples can be informative about the importance of islands' placement: the Mycenaean connection $\left(17^{\text {th }}-12^{\text {th }}\right.$ centuries BCE) and the Malvasia wine export of the $19^{\text {th }}$ century.

\subsubsection{Visual landscapes}

Perception of the landscape, especially in the case of islands, is strongly influenced by the view that one has of the surrounding environment. Moreover, people organize space employing mental maps in which travelling time, direction and landmarks are major characteristics [Broodbank, 2000]. Landmarks are particularly important features 


\section{Andrea Di Renzoni et al.}

for the understanding of the surrounding world and the ability to move in an (homogeneous) environment strictly depends on their recognition.

The Aeolian Archipelago can be grouped into three main sectors, defined not only geographically but also by geological (tectonic) setting of the areas where the islands were built upon the seafloor: Alicudi and Filicudi in the western sector; Vulcano, Lipari and Salina in the central sector; Panarea and Stromboli in the eastern sector. Vulcano, Lipari, Panarea and Stromboli are along a line nearly parallel to the Calabrian coast. Vulcano is $22 \mathrm{~km}$ from Milazzo (on the NE coast of Sicily) and very close to Lipari. Panarea is $14 \mathrm{~km}$ from Lipari and Stromboli is $18 \mathrm{~km}$ from Panarea (23 considering the main village on the island). Salina is only $5 \mathrm{~km} \mathrm{NW}$ from Lipari, while Filicudi is more than 20 $\mathrm{km}$ from Salina and Alicudi, almost $20 \mathrm{~km}$ from Filicudi. Considering Sicily as mainland, Vulcano is the nearest island to the mainland (22 km from Milazzo), Stromboli is $54 \mathrm{~km}$ from the Tropea area (Calabrian coast) and Alicudi $52 \mathrm{~km}$ from Capo d'Orlando (Sicily) (Figure 1).

Mainly due to the orography, villages on the islands are generally placed on their east side and the same positions have been chosen over time. The Acropolis of Lipari and the area around it have been the main centre of the island since the Neolithic. The island of Salina is now divided into three municipalities, separated by the "Monte delle Felci" and "Monte dei Porri": Malfa on the north coast, Leni on the south coast and Santa Marina on the east coast; very ancient archaeological traces are in the area of Leni, where a Neolithic (Stentinello facies) hut has been excavated, and in Santa Marina, where the most ancient site dates to the early Copper Age. The modern village of Panarea is along the east coast of the island in the same position as a Copper Age (Piano Quartara facies) settlement and a Bronze Age (Peppemaria) site. On Filicudi island the modern village is on the east side of the mountain "Fossa delle Felci" and along the isthmus of Piano del Porto, where the most ancient human traces (Neolithic, Diana facies) have been discovered. The Bronze Age village of Alicudi, Punta Fucile, is close to the modern village of the island, on the south-west coast. The main village of the island of Stromboli is on the north-east side of the island where the first human traces have been recognized; the other village, Ginostra, is on the south coast of the island, where Copper Age and Bronze Age traces have been found. On the island of Vulcano the most densely inhabited area is on the north-east edge of the island; the immediate upper land has been chosen as view-point. The northernmost and low-lying sector of the island (Vulcanello) emerged from the sea with its lava platform in Medieval time, between 10th and 11th century AD [Malaguti et al., 2021] as also supported by hystorical sources [Manni and Rosi, 2021 this volume]. The sandy isthmus connecting the Vulcanello platform to the main Vulcano Island was definitively formed in the first half of the 16th century $\mathrm{AD}$, allowing the creation of the flat area where the Porto Village was settled [Manni and Rosi, 2021 this volume].

Seven locations, corresponding to the places where a long lasting human presence is recorded, have been chosen as observer points to perform a viewshed analysis (r.viewshed Grass 7.8.2 module): the Acropolis of Lipari; Santa Marina and Leni on Salina; Peppemaria on Panarea; the village of Alicudi; the Montagnola of Filicudi; San Vincenzo on Stromboli and the area above the modern harbour of Vulcano. The result is shown in Figure 5. There is a clear distinction between the western and (central-) eastern sector of the archipelago, Lipari (Figure 5.B), Panarea (Figure 5.C) and Stromboli (.A) have a very similar field of view, embracing the Strait of Messina and the Calabrian coast. The field of view from Salina - Santa Marina (Figure 5.F) and Vulcano (Figure 5.E) is similar but with a lesser width. Completely different is the field of view from Salina - Leni (Figure 5.I), Alicudi (Figure 5.G) and Filicudi (Figure 5.H): these observer points have almost the same visual landscape, corresponding to the Sicilian coast, west of Milazzo. It is worth noting that the positions chosen for Lipari, Panarea and Stromboli do not allow a good visibility of the other islands while there is good intervisibility among the western islands.

The easternmost islands, especially Stromboli with its summit that reaches ca $1000 \mathrm{~m}$, were easily recognizable landmarks that strongly characterize the landscape of the Southern Tyrrhenian sea. From Poro promontory (Tropea), Lipari and Vulcano, Panarea and Stromboli are visible (Figure 5.D) and easily recognizable. It can be imagined that their positions (more simply than the continuous landscape of the coast) were used as landmarks during navigation.

\subsubsection{Mycenaean routes}

As stated above, during the early Bronze Age (at least during the Late Helladic I) Mycenaean élites promoted the first exploratory journeys westward. Some possible routes have been identified [Marazzi, 2016], one of which is through the strait of Messina. The Aeolian archipelago was an important hub along this latter route: approximately 

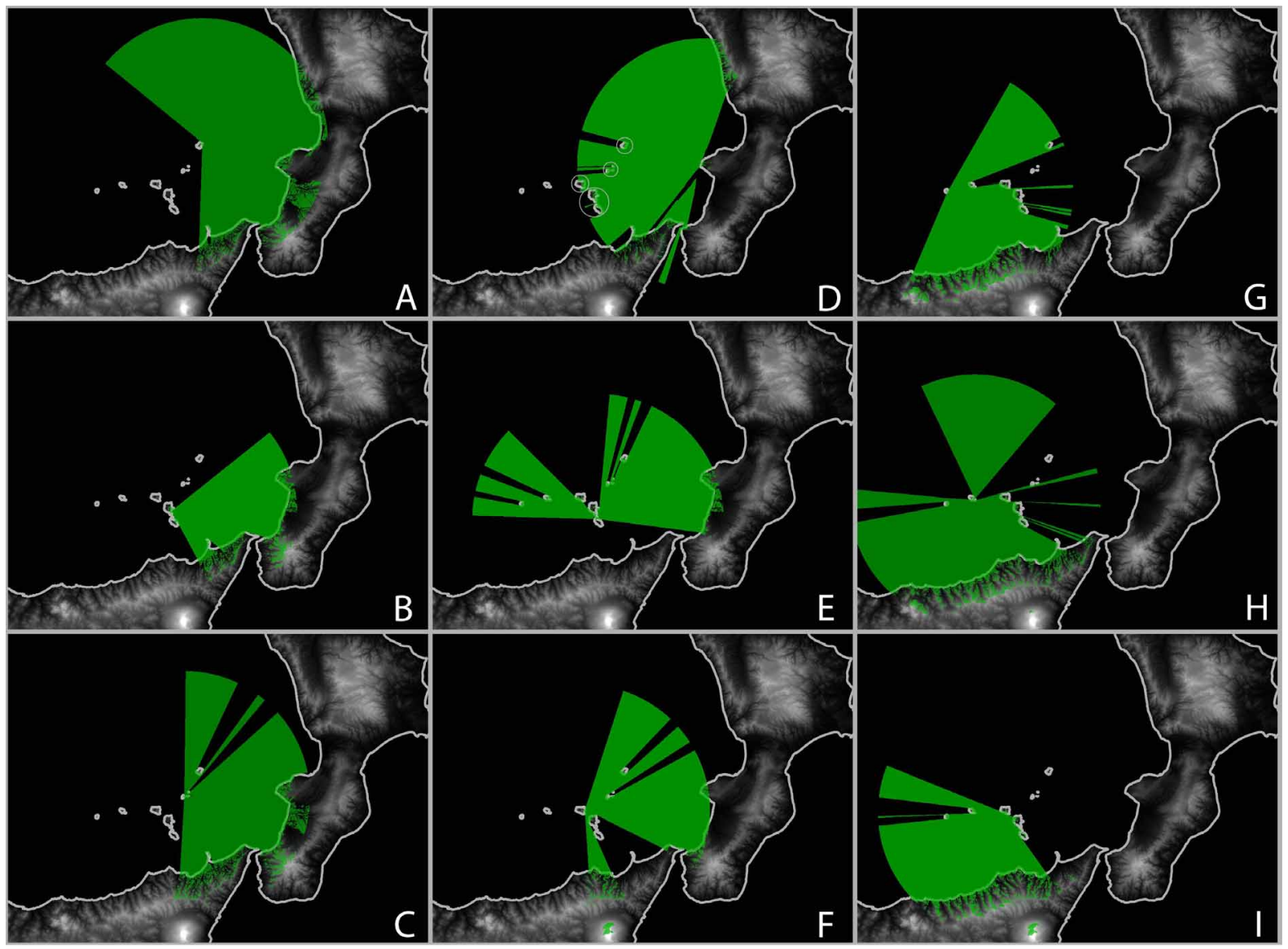

0

$50 \quad 100 \quad 150 \quad 200 \mathrm{~km}$

Visible area

Figure 5. Field of view maps of the archipelago. A: Stromboli; B: Lipari; C: Panarea; D: Poro promontory; E: Vulcano; F: Salina - Santa Marina; G: Alicudi; H: Filicudi; I: Salina - Leni.

500 pieces of Aegean pottery have been found in Lipari, Panarea, Salina, Filicudi and Stromboli, while only few have been recognized, up to now, on the north-eastern coast of Sicily, in the site of Milazzo - Viale dei Cipressi and on the Island of Ustica. Probably volcanic by-products attracted Aegean mariners and, if the whole phenomenon of the Aegean presence in Italy is considered (approximately 2500 finds), the quantity of pottery found in the Aeolian Islands, particularly on Lipari, demonstrates an intense relationship of the Archipelago with the eastern Mediterranean [Brunelli et al., 2013; Jones et al., 2014]. The preminent role played by the Archipelago in the Mediterranean network of the late $3^{\text {rd }}$ early $2^{\text {nd }}$ millennium is underlined by some author that suggest that little islands (Aeolian, Maltese Archipelago) had a strategic function in the western expansion of the Aegeans. Thanks to their location they acted as precious centres organizing exchange activities [Cazzella and Recchia 2013; Cazzella and Recchia, 2018]. The earliest Aegean imported pottery dates to Late Helladic I-II, and has been found on Lipari, Filicudi, Stromboli and in minor amount on Salina. Later sherds are also known from Lipari, Panarea and Salina. The Aeolian hub was both a place for the exploitation of volcanic resources and a stepping-stone to the middle Tyrrhenian sea.

\subsection{3 $19^{\text {th }}$ century wine routes}

The $19^{\text {th }}$ century was a period of great intensification of maritime commercial traffic in the Mediterranean. The Aeolian Islands were an important node of this network, linking Sicily to the Italian peninsula and to Sardinia. Lipari and Stromboli, because of their position, were the most involved islands [Giacomantonio, 2010]. 


\section{Andrea Di Renzoni et al.}

The islands exported raisins and wine, mainly the famous Malmsey of Lipari, one of the most renowned products of the archipelago. The best Malmsey grapes were cultivated on Salina and Stromboli (Figure 6). In 1841, Carlo Rodriquez wrote that in $1800 \mathrm{AD}$ the Aeolians shipped about 2,000 barrels of wine and 16,000 barrels of "Passolina" (Malmsey-like) to Napoli, Palermo, Messina, Roma, Livorno, Marseille and Trieste.

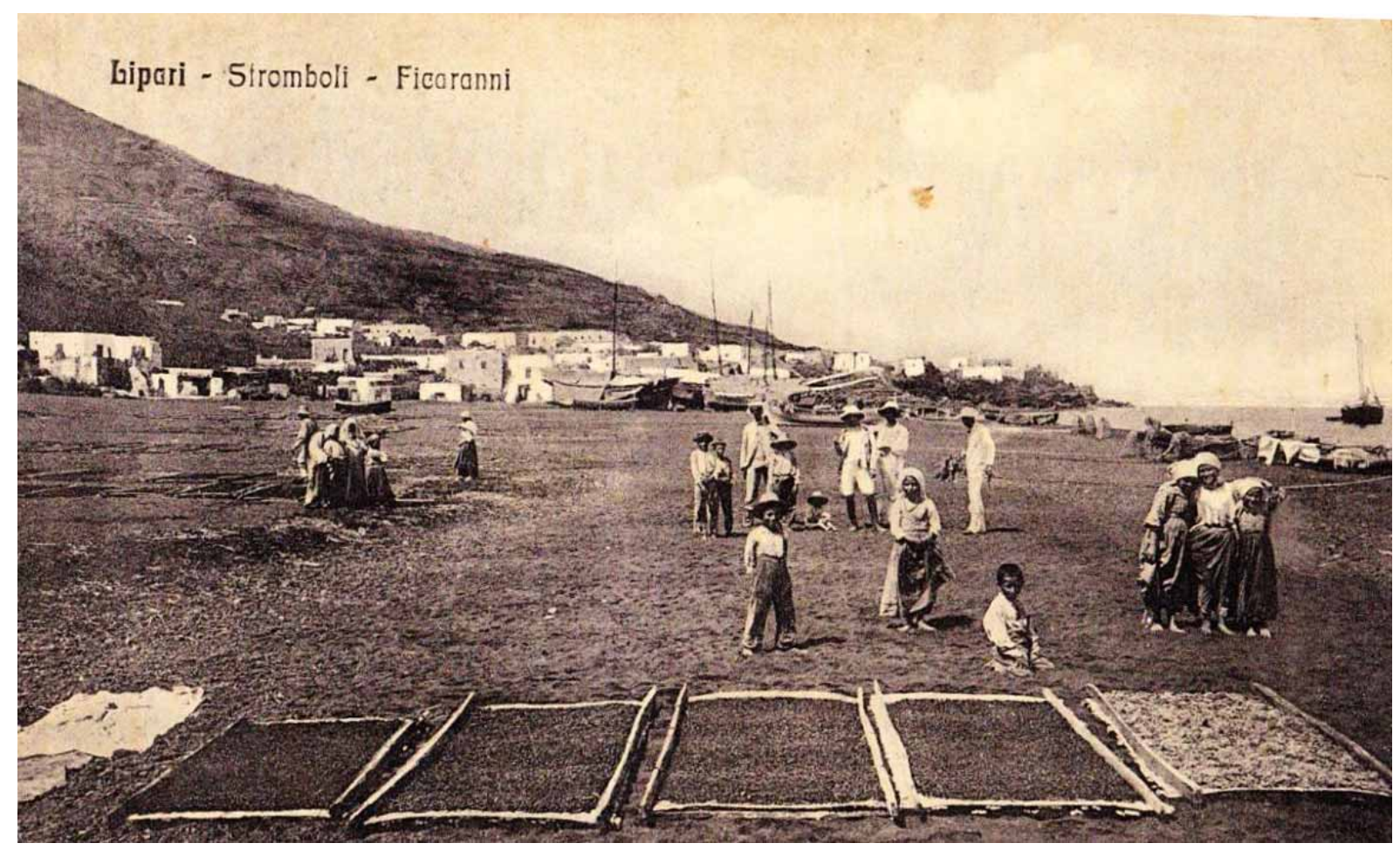

Figure 6. Pictures of Stromboli - Ficogrande, Malmsey drying during XIX century.

(http://www.archiviostoricoeoliano.it/wiki/xix-secolo-fra-segni-di-crescita-ed-eventi-rivoluzionari).

During the second half of the $19^{\text {th }}$ century the "fillossera" (Phylloxera vitifoliae), a pest of commercial grapevines, originally native to eastern North America, spread all over Europe. The insect infected $24 \%$ of Sicilian cultivation in the period between 1891 and 1894 [Lentini, 2015], and at beginning of the $20^{\text {th }}$ century the epidemic reached the Aeolian Islands, putting an end to their commercial expansion.

\section{Stromboli}

\subsection{Volcanological evolution of the Stromboli island}

Stromboli is an active volcano, representing the subaerial part of a large volcanic edifice extending from ca $2 \mathrm{~km}$ below sea level (bsl) to $924 \mathrm{~m}$ above sea level (asl; Figure 7). This volcano inspired the name of the so-called "Strombolian activity" used worldwide and is therefore the archetype for this type of eruption. The present-day persistent activity of Stromboli is characterized by mild intermittent explosions that originate from active summit vents nested within an area of $300 \times 100 \mathrm{~m}$, called the "Crater Terrace" at ca 750 metres asl in the upper part of the Sciara del Fuoco, which is a horseshoe-shaped collapse scar cut in the NW flank of the cone.

The subaerial evolution of Stromboli is the result of constructional effusive and explosive activity in the last ca 100 ka (Figure 7.c), also coupled with destructive phases of caldera and sector collapses [Hornig-Kjarsgaard et al., 1993; Tibaldi, 2001]. With the exception of the islet of Strombolicchio (a volcanic neck) which is ca. 200 ka [Gillot and Keller, 1993], the oldest subaerial eruptive periods are represented by Paleostromboli I ( $85-75 \mathrm{ka}$ ), II (67-54 ka) and III (ca 41- 


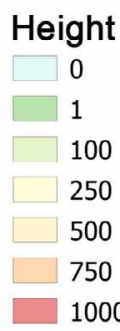

A

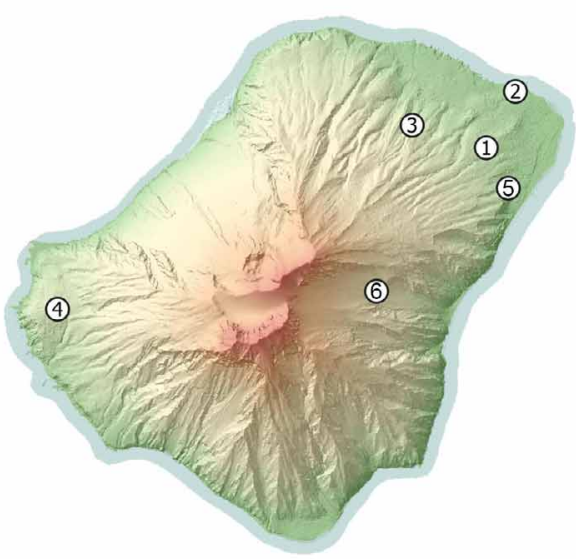

Strombolicchio

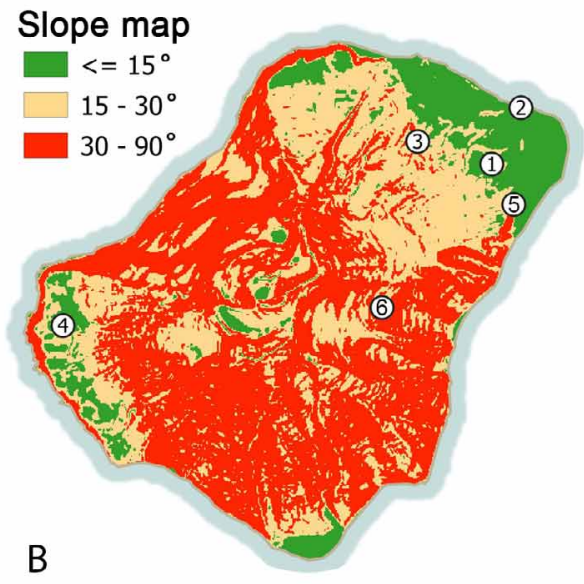

B

C

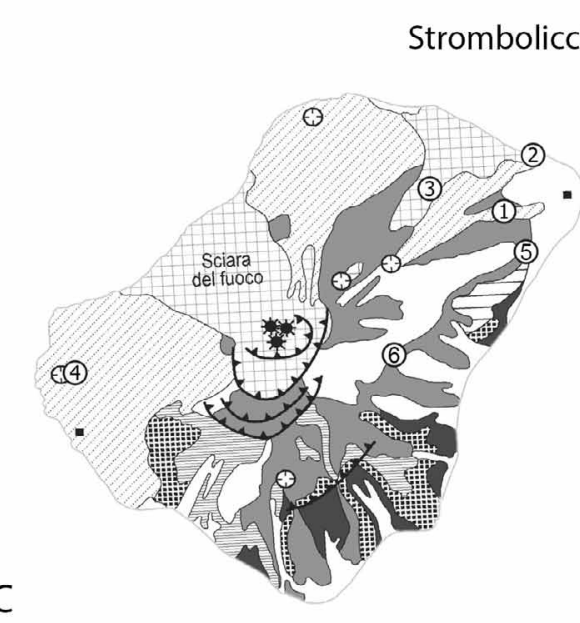

Figure 7. Position of the archaeological sites of Stromboli (1-4) and of the dripping points (5-6). A: altimetry base-map; B; slope base-map; C: Simplified geological map of the Stromboli volcano (modified after Hornig-Kjarsgaard et al. [1993]). The ages of the various periods of the subaerial activity are mainly from Figure 1 of Risica et al. [2019]. Neostromboli is also constrained with stratigraphic and volcanological reconstruction from Vezzoli et al. [2014]. Numbers in the circles refer to: 1: San Vincenzo Copper Age, Bronze Age, Greek, Roman and Medieval archaeological site; 2: Ficogrande Greek necropolis; 3: Serra Fareddu Copper Age settlement; 4: Timpone del Fuoco Copper Age and Bronze Age site; 5: Casa Schicciola dripping point; 6: Le Schicciole dripping point.

34 ka) and Vancori (ca 26-13 ka; Figure 7.c). Later on, a Holocene volcanic edifice called Neostromboli developed. It is an asymmetrical lava cone that grew within the collapse amphitheatre formed at the end of the Vancori period [Vezzoli et al., 2014]. The early stage of the Neostromboli activity occurred at 9-8 ka BP and was characterized by summit lava flow units blanketing both the SW and northern volcano flanks. After ca 7.5 ka lateral eruptions from peripheral cones and fissures became dominant [Risica et al., 2019]. The end of the Neostromboli activity is marked by the NW sector collape of the Neostromboli edifice (6 ka; Rosi M., reported in Speranza et al. [2008]) which triggered a phreatomagmatic eruption (Secche di Lazzaro pyroclastics [Bertagnini and Landi, 1996; Renzulli and Santi, 1997] and outlined the Sciara del Fuoco mostly as we see it nowadays. No clear eruptions are attested shortly after the end of the Neostromboli period, although activity shifted to the so-called Recent Stromboli, dominantly characterized by central-vent summit activity, with recurrent explosive eruptions separated by short-lived periods of quiescence or lower activity and subordinate fissure-like eccentric eruption along the north-eastern flank of the island (such as the San Bartolo lava flow in the Greek-Roman period; dated between 360 BCE and $7^{\text {th }}$ century AD by paleomagnetic data [Speranza et al., 2008]. The "Pizzo Sopra la Fossa" formation [Hornig-Kjarsgaard et al., 1993], a thick planar-bedded succession of strombolian fallout scoriae which is discontinuously exposed in the summit 


\section{Andrea Di Renzoni et al.}

region of Stromboli and along the upper slopes of the eastern flanks represents the early stage of activity of Recent Stromboli. Repeated episodes of summit explosive activity (Post-Pizzo series and Lower Sequence deposits [HornigKjarsgaard et al., 1993; Rosi et al., 2000] between the $4^{\text {th }}$ century BCE and the $1^{\text {st }}$ century AD) preceded the present-day eruptive style, characterized by persistent mild explosive events broken by rarer paroxysms (and lava flows along the Sciara del Fuoco). This transition occurred between the $3^{\text {rd }}$ and $7^{\text {th }}$ century AD [Rosi et al., 2000] and evidence of paroxysms continued up to the end of the Middle Ages, at places also associated with landslides along the Sciara del Fuoco and relative tsunamis [Rosi et al., 2019].

The products of the persistent activity are represented by black basaltic scoria lapilli and ash which normally accumulate on and near the Crater Terrace and are subjected to burial, reheating and chemical alterations due to fluid percolation induced by the heating and degassing of the underlying magma-hydrothermal system [Del Moro et al., 2011, 2013; Renzulli et al., 2021].

The active degassing during the mild explosions is coupled with continuous passive degassing of the magma, resulting from the open-vent system and "puffing", this latter being the typical degassing mode of the volcano consisting of the emission of small over-pressurised gas jets/pockets [Harris and Ripepe, 2007].

The persistent activity erupts a high porphyritic basaltic magma (HP shoshonitic basalt), stored at relatively shallow depth. This HP magma can also periodically outpour as lava flows (along the Sciara del Fuoco) whereas gas-rich, low porphyritic (LP) and deeper fast uprising shoshonitic basalt, with nearly the same whole rock compositions as the HP one, can be occasionally erupted during more violent (major eruptions) or paroxystic explosion (paroxysms) as highly vesicular pumices together with HP products [Métrich et al., 2001; Bertagnini et al., 2003]. Paroxysms, major eruptions and possible under recording of major explosions are reported in Figure 8 [Bevilacqua et al., 2020].

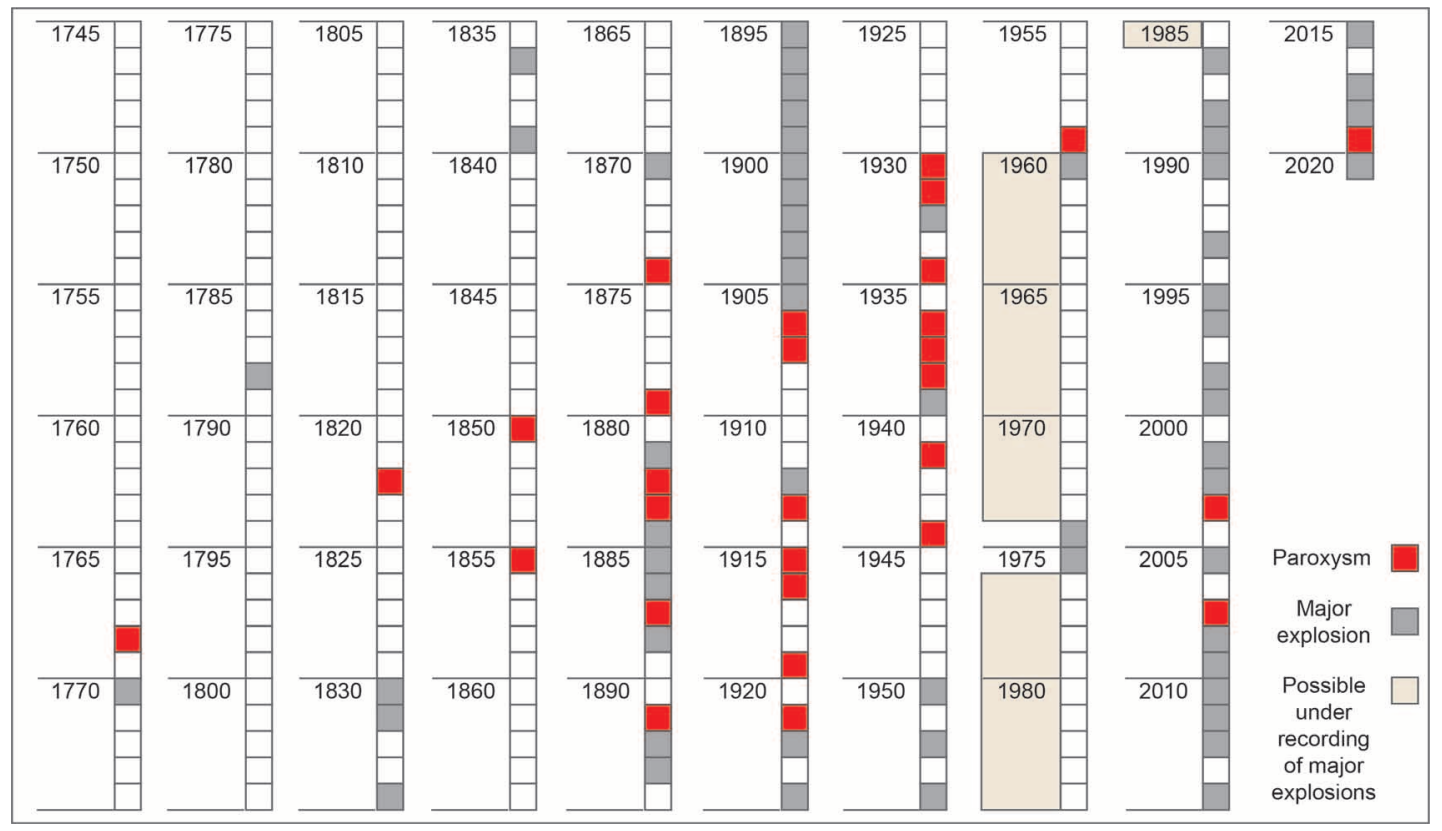

Figure 8. Schematic representation of the most relevant volcanic activity in the Island of Stromboli recorded in the last 250 years (after Bevilacqua et al. [2020] and http://www.archiviostoricoeoliano.it/wiki/allegati-pdf-sullattivitadello-stromboli-e-sul-vulcanesimo-genere).

Paroxysms consists of sequences of explosions from different craters lasting from a few minutes to days or even weeks, as reported in November 1882 and April 1907 [Bertagnini et al., 2011 and references therein]. Cannon-shotlike detonations and window-breaking pressure waves are accompanied by the formation of kilometre-high convective columns of gas, and incandescent materials, generating fallout of decimetre-sized bombs, lapilli and ash onto the volcano slopes. During the largest paroxysms, metre-sized ballistic lithic blocks 
and spatter are ejected onto the flanks of the volcano down to very low elevations [Rosi et al., 2006; Renzulli et al., 2009], occasionally reaching the villages of Stromboli and Ginostra, and tsunamis can also occur generated from sector collapses of Sciara del Fuoco [Barberi et al., 1993; Tinti et al., 2003]. A good, almost continuous record of these paroxysmal events exists at least since the end of the $19^{\text {th }}$ century [Barberi et al., 1993] and they also had an impact on inhabited areas: 22 May 1919 eruption with 4 casualties or the dramatic 11 September 1930 eruption with 6 casualties. In the last two decades, paroxysmal eruptions of Stromboli seem to have occurred more frequently than during the last 50 years of the $20^{\text {th }}$ century. The best investigated paroxysms in this 20 -year time interval are represented by those of 5 April 2003 [Rosi et al., 2006], 15 March 2007 [Pistolesi et al., 2011], 3 July (1 casualty) and 28 August 2019 [Giordano and De Astis, 2021].

\subsection{History of human presence on the island of Stromboli.}

Human presence on the island of Stromboli has been attested for almost six millennia, although the lack of archaeological evidence related to certain periods suggests the island was not inhabited continuously. The research on the island has not been systematic: some sites (cf San Vincenzo, Figure 7) have long been investigated while other areas are completely unexamined; furthermore Holocene lava flows may have covered previous human traces (e.g. the San Bartolo lava emplaced between 360 BCE and $7^{\text {th }}$ century AD in the north eastern flank of the island [Speranza et al., 2008], may have subtracted important data from the archaeological enquiry). For these reasons, in active volcanoes such as Stomboli island, the absence of traces related to a particular historical period might be not real but rather the result of recent eruptions. The following review is a summary, at present, of the historical and archaeological data about human settlement on Stromboli and the most significant events that also concerned the other islands of the whole Aeolian Archipelago (Table 3).

\subsubsection{Prehistory}

\subsubsection{Copper Age}

The most ancient traces of human presence on the island are some pottery sherds pertaining to the Spatarella facies (4100-3800 BCE; 3950-3650 BCE), found in the site of San Vincenzo. Although the fragments were found in the layers of the Bronze Age village, whose structures might have destroyed the stratigraphy of an older site, more probably they testify to a weak and sporadic human activity [Cavalier, 1981; Bettelli et al., 2016].

The following archaeological period, Pianoconte facies [3800-2800 BCE, according to Martinelli et al. 2021, 3650-3300 BCE, according to Pacciarelli 2011], is attested by the site of Serra Fareddu, behind the locality of Piscità at about $230 \mathrm{~m}$ above sea level. Although the site has been only briefly investigated in 1976, the quantity and preservation of pottery sherds suggest its interpretation as a stable village [Cavalier 1979a]. Recently, a piece of charcoal preserved in the museum of Lipari has been analysed (together with the other finds collected in 1976), whose dating is congruent with the Pianoconte facies (4510 \pm 30 BP; 95.4\% interval: 3355-3260 BCE - $31.5 \%$, 32503099 BCE - 63.9\%, Laboratory: Beta Analytics - 499386; Calibration: OxCal4.4, IntCal20). On the other side of the island, labile archaeological traces of the Pianoconte facies are known [Martinelli and Lo Cascio, 2018], although their interpretation is difficult.

A very small number of sherds found in Ginostra (Bernabò Brea, Cavalier, pp. 45-46), on the south side of the island, are the only clear evidence about Piano Quartara facies (2800-2200 BCE according to Martinelli et al. [2021], 3050-2350 BCE, according to Pacciarelli [2011]) occupation. Excluding a radiometric dating obtained from charcoal found in the lower layers of the site of San Vincenzo (3896 \pm 43 BP; 95.4\% interval: 2475-2275 BCE 88.7\%, 2256-2206 BCE - 6.7\%, Laboratory: Milano Bicocca - RC412; Calibration: OxCal4.4, IntCal20), evidence of Piano Quartara facies is not known on the north side of the island. 
Andrea Di Renzoni et al.

\begin{tabular}{|c|c|c|c|c|}
\hline Chronology & $\begin{array}{l}\text { Population } \\
\text { rate }\end{array}$ & Typology & Description & References \\
\hline $1961-1971$ & Low intensity & Census data & $\begin{array}{c}\text { Minimum number of inhabitants in modern period } \\
\qquad(1961=560,1971 \text { ca } 400)\end{array}$ & [Pitto, 1990 p. 71] \\
\hline 1930 & Mid intensity & Volcanic event & September $11^{\text {th }}$, violent eruption that caused 6 deaths. & $\begin{array}{l}\text { [Bevilacqua et al., } 2020 \text { and } \\
\text { reference therein] }\end{array}$ \\
\hline 1919 & High intensity & Volcanic event & May $22^{\text {nd }}$, violent eruption that caused 4 deaths & $\begin{array}{l}\text { [Bevilacqua et al., } 2020 \text { and } \\
\text { reference therein] }\end{array}$ \\
\hline 1891 & High intensity & Census data & Maximum number of inhabitants in modern period (2716) & [Pitto, 1990 p. 71] \\
\hline 1864 & High intensity & Census data & 1827 inhabitants ( 753 males and 1075 females) & [Fazio, 2008 p. 129] \\
\hline 1800 & High intensity & Census data & 1200-1400 inhabitants at the end of XVII century & [Barnao, 2017] \\
\hline 1730 & Low intensity & Historical event & building of San Vincenzo and Ginostra churches & $\begin{array}{l}\text { [Giacomantonio, } 2010 \\
\text { p. 253] }\end{array}$ \\
\hline 1702 & Low intensity & Historical event & $\begin{array}{c}\text { first colonists, stimulated Bishop Girolamo Ventimiglia, } \\
\text { settled in Ginostra }\end{array}$ & $\begin{array}{l}\text { [Giacomantonio, } 2010 \\
\text { pp. 230-231] }\end{array}$ \\
\hline $1500-1700$ & $\begin{array}{l}\text { Very low } \\
\text { intensity }\end{array}$ & $\begin{array}{l}\text { Literary } \\
\text { data }\end{array}$ & little presence on the island (fishermen, slaves, pirates) & $\begin{array}{l}\text { [Giacomantonio, } 2010 \\
\text { p. 179-182] }\end{array}$ \\
\hline 1544 & & Historical event & $\begin{array}{l}1544 \text { Lipari was destroyed by Khair-ed-Din, } \\
\text { also known as Ariadeno il Barbarossa }\end{array}$ & $\begin{array}{l}\text { [Giacomantonio, } 2010 \\
\text { p. 146-169] }\end{array}$ \\
\hline 1456 & Low intensity & Volcanic event & $\begin{array}{l}\text { Historical document (De Bindis letter) describing effects of } \\
\text { tsunami corresponding to a tephra layer dated to } 1400-1500\end{array}$ & [Rosi et al., 2019] \\
\hline 1393 & Low intensity & Volcanic event & $\begin{array}{c}\text { Historical document (Bonincontri letter) describing effects of } \\
\text { tsunami }\end{array}$ & [Rosi et al., 2019] \\
\hline $1350-1400$ & Low intensity & $\begin{array}{l}\text { Archaeological } \\
\text { evidence }\end{array}$ & $\begin{array}{l}\text { Medieval necropolis on the ruins of a former church, last } \\
\text { material traces of human presence attested on the island } \\
\text { during medieval period }\end{array}$ & [Rosi et al., 2019] \\
\hline 1343 & Mid intensity & Volcanic event & $\begin{array}{l}\text { Historical document (Petrarca letter) } \\
\text { describing effects of tsunami }\end{array}$ & [Rosi et al., 2019] \\
\hline $1200-1350$ & Mid intensity & $\begin{array}{l}\text { Archaeological } \\
\text { evidence }\end{array}$ & $\begin{array}{l}\text { San Vincenzo: Late medieval church } \\
\text { (radiometric dates 1080-1350) }\end{array}$ & [Rosi et al., 2019] \\
\hline $1250-1300$ & & Volcanic event & $\begin{array}{l}\text { Eruptions of Forgia Vecchia, Lami and Rocche Rosse } \\
\text { in the north-eastern sectors of Lipari } \\
\text { (explosive events and obsidian lava flows). } \\
\text { Rocche Rosse pumice tephra dispersed towards south }\end{array}$ & [Pistolesi et al., 2021] \\
\hline $\begin{array}{c}\text { Between } \\
10-11^{\text {th }} \text { century }\end{array}$ & & Volcanic event & Formation of the subaerial lava platform of Vulcanello & [Malaguti et al., 2021] \\
\hline $8^{\text {th }}$ century & & Volcanic event & $\begin{array}{l}\text { Eruptions of Monte Pilato in the north-eastern sectors of } \\
\text { Lipari (explosive event and obsidian lava flow). } \\
\text { Pumice tephra dispersed towards north-east }\end{array}$ & [Pistolesi et al., 2021] \\
\hline \multicolumn{5}{|c|}{ GAP (ca 700 yr) } \\
\hline $100-500$ & $\begin{array}{l}\text { Mid/High } \\
\text { intensity }\end{array}$ & $\begin{array}{l}\text { Archaeological } \\
\text { evidence }\end{array}$ & San Vincenzo: Roman period tombs & [Ferranti et al., 2015] \\
\hline $251 \mathrm{BCE}$ & & Historical event & Lipari conquered by Romans & [Cavalier, 1979b] \\
\hline 320-250 BCE & High intensity & $\begin{array}{l}\text { Archaeological } \\
\text { evidence }\end{array}$ & $\begin{array}{l}\text { San Vincenzo: Greek pottery } \\
\text { Ficogrande: Greek necropolis }\end{array}$ & [Cavalier, 1979b] \\
\hline $\begin{array}{l}580-576 \text { BCE } \\
(629 / 626) \text { BCE }\end{array}$ & Low intensity & Historical evidence & $\begin{array}{l}\text { Foundation of the Greek colony of Lipari } \\
\text { (San Girolamo; Diodorus, book V, chapter 9) }\end{array}$ & [Cavalier, 1999] \\
\hline \multicolumn{5}{|c|}{ GAP (ca 1000 yr) } \\
\hline 1900-1500 BCE & High intensity & $\begin{array}{l}\text { Archaeological } \\
\text { evidence }\end{array}$ & $\begin{array}{c}\text { San Vincenzo: Bronze Age settlement } \\
\text { (Capo Graziano facies) } \\
\text { Ginostra - Timpone del Fuoco: Bronze Age pottery sherds } \\
\text { (Capo Graziano facies) }\end{array}$ & $\begin{array}{l}\text { [Bettelli et al., 2016; Vidale } \\
\text { et al., 2018] } \\
\text { [Bernabò Brea and Cavalier, } \\
1968 \text { pp. 45-46] }\end{array}$ \\
\hline 3300-2300 BCE & Low intensity & $\begin{array}{l}\text { Archaeological } \\
\text { evidence }\end{array}$ & $\begin{array}{c}\text { Ginostra - Timpone del Fuoco: Copper Age pottery } \\
\text { sherds (Piano Quartara facies) }\end{array}$ & $\begin{array}{l}\text { [Bernabò Brea and Cavalier, } \\
1968 \text { pp. } 45-46]\end{array}$ \\
\hline 3800-3300 BCE & Mid intensity & $\begin{array}{l}\text { Archaeological } \\
\text { evidence }\end{array}$ & $\begin{array}{c}\text { Serra Fareddu: Copper Age settlement } \\
\text { (Pianoconte facies). } \\
\text { Ginostra - Timpone del Fuoco: Copper Age settlement } \\
\text { (Pianoconte facies) }\end{array}$ & $\begin{array}{c}\text { [Cavalier ,1979a pp. } \\
\text { p. 126-132] } \\
\text { [Bernabò Brea and Cavalier, } \\
\text { 1968 pp. 45-46] }\end{array}$ \\
\hline 4000-3800 BCE & Low intensity & $\begin{array}{l}\text { Archaeological } \\
\text { evidence }\end{array}$ & $\begin{array}{l}\text { San Vincenzo: Early Copper Age pottery sherds } \\
\text { (Diana - Spatarella facies) }\end{array}$ & [Bettelli et al., 2016] \\
\hline
\end{tabular}

Table 3. Chronological scheme of the human presence on the Island of Stromboli. Some historical events in the whole Aeolian Archipelago as well as some eruptions are also reported. 


\subsubsection{Bronze Age}

The Bronze Age was a flourishing period for the Aeolian Islands. At the beginning of the period, during the Capo Graziano facies ( $22^{\text {nd }}-15^{\text {th }}$ centuries), all the islands (except Vulcano) were inhabited, and on the biggest islands more than one settlement were founded. According to some authors, this burst of population has to be related to the movement of small human group from Greece in the context of the late $3^{\text {rd }}$ millennium Mediterranean network (see $\S$ 3.5.2), as the finds from the Altis of Olympia and Androvida-Lescaina would suggest [Bernabò Brea, 1985; Cazzella and Recchia, 2013; Cazzella et al., 2020].

At San Vincenzo, on the island of Stromboli, a big village occupied a plateau whose north-east margin corresponds to the centre of the modern village. The site, identified at the end of the 1970s [Cavalier, 1979a], was investigated in 1980 and since 2009 is the object of an interdisciplinary project led by the University of Modena and Reggio Emilia and Hunter College of NY. The excavations have revealed a complex topographic organization of the village, huge terrace walls defined big enclosures and sustained flat areas occupied by circular huts [Bettelli et al., 2016; Levi et al., 2017; Vidale et al., 2018].

Capo Graziano pottery sherds have been also found also at Ginostra, on the south side of the island, although no remains of a village or hamlet are known [Bernabò Brea and Cavalier, 1968].

The last Bronze Age finds on the island of Stromboli date to the $14^{\text {th }}$ century BCE, corresponding to the end of the Capo Graziano facies and the beginning of the Milazzese facies. This was a period of deep changes in the settlement pattern: the islands of Alicudi [Cavalier, 1979a] and Stromboli seem to have been abandoned; the village of Montagnola, on the island of Filicudi, was strongly re-organized [Bernabò Brea and Cavalier, 1991]; the sites of Peppemaria and Calcara on the island of Panarea, were forsaken and a new village was settled [Bernabò Brea and Cavalier, 1968]. In the village of Punta Milazzese some Capo Graziano pots have been found, supposed to be related to a cult place [Bernabò Brea and Cavalier, 1968]. On the island of Salina two villages were abandoned, another two continued to be occupied and a new one, Portella, was settled [Bernabò Brea and Cavalier, 1968, 1995; Martinelli, 2005; 2011]. At Lipari, only the main village on the Acropolis was still active. In fact, an isolated sherd dated to the Milazzese facies has been found on the side of Monte della Guardia [Cavalier, 1979a]. This phenomenon is even more perceivable during the late Bronze Age $\left(12^{\text {th }}-10^{\text {th }}\right.$ centuries BCE) when, in the entire Archipelago, only the village on the Acropolis of Lipari was occupied.

\subsection{Classical period}

The centuries after the Ausonio II, the last Bronze Age Aeolian facies corresponding to the final Bronze Age, are a long period of low anthropic presence for the whole archipelago. M. Cavalier in 1999 stated that immediately before the foundation of the Cnidian colony of Lipari, the island was occupied by few people, about 500 according to the writing of Diodorus. She further added that on the Acropolis of Lipari, Greek layers were immediately above the Late Bronze Age layers related to the violent destruction of the Ausiono II village (thought to be caused by population from south Italy), testifying to a long period of abandonment of the area [Cavalier, 1999].

The lack of archaeological remains indicates that Stromboli was not occupied for a long period after the Bronze Age. A new flourishing period is during the $5^{\text {th }}-4^{\text {th }}$ century BCE, as testified by the archaeological record. At Ficogrande the discovery of a necropolis with rich grave goods is the most relevant proof of the presence on the island of a stable and prospering settlement. Further data are from the area close to the site of San Vincenzo where a huge quantity of well-preserved pottery dated to the same period has been found [Cavalier, 1979b].

The same seem to have happened to the other islands, where a stable population is supposed from the $5^{\text {th }}-4^{\text {th }}$ century BCE [Cavalier, 1999].

The site of San Vincenzo also offers the data to infer a stable human presence during Roman times, particularly during the imperial period. Although the analysis is still in progress, many of the diagnostic sherds can be dated between 100 and $200 \mathrm{AD}$, and between the $4^{\text {th }}$ and $6^{\text {th }}$ centuries $\mathrm{AD}$. To the latter period can be dated four tombs, identified in two distinct excavation areas [Ferranti et al., 2015], while 6 coins, found dispersed in the excavation trenches, can be dated to the $4^{\text {th }}$ century. 


\section{Andrea Di Renzoni et al.}

\subsection{Medieval period}

The end of Roman times marks another long period in which Stromboli seems to be uninhabited, a phenomenon that affected all the islands of the archipelago, from the $6^{\text {th }}$ to the $11^{\text {th }}$ century $\mathrm{AD}$, with a possible height triggered by the eruption of Monte Pilato on Lipari in the $8^{\text {th }}$ century AD [Manni et al., 2019].

Recent discoveries from the northern area of the San Vincenzo excavation indicated the presence of an important human settlement during the late medieval period, as the discovery of a church with an apsidal plan suggests. The building suddenly suffered a traumatic, never restored, collapse of the roof. Three graves were excavated into the remains of the fallen roof, probably immediately after the collapse. At the top of the stratigraphy over the church, a thick level of tephra has been identified; the same tephra has been recognised in other excavation areas. This tephra layer has been correlated with a similar layer found in geological trenches opened close to the NE coastline of Punta Lena. There, the tephra layer was found immediately above a clear tsunami deposit. Traces of other two tsunami waves were found deeper, below the upper tsunami. The chronology of the oldest tsunami is coherent with the collapse of the church (ca mid $14^{\text {th }}$ century $\mathrm{AD}$ ); the intermediate tsunami is roughly contemporaneous with sporadic human activities in the area (end of $14^{\text {th }}$ century $\mathrm{AD}$ ), as the presence of several coins found in the excavation confirms, while the upper tsunami seems to mark the end of the anthropic presence in the $14^{\text {th }}-15^{\text {th }}$ century AD [Rosi et al., 2019; Pistolesi et al., 2020]. The human and environmental events at Stromboli during the late medieval phase are also described in two documentaries directed by Pascal Guérin and produced by ZED: Tsunamis, une menace planétaire 2019; Stromboli: a provocative island, 2020).

\subsection{Modern period}

\subsection{1 $15^{\text {th }}-17^{\text {th }}$ century}

After the Middle Ages, data about human presence on the island of Stromboli are rare and discontinuous. Generally, historical data about the Aeolian Islands during the $15^{\text {th }}$ century are scarce [Giacomantonio, 2010], and they mainly concern Lipari and the problem of piracy. At the end of the 1400s AD Lipari counted about six thousand inhabitants while the other islands, apart from Salina, seem to have been poorly occupied.

In $1544 \mathrm{AD}$ Lipari was destroyed by Khair-ed-Din, also known as Ariadeno il Barbarossa. After the plunder, the population lived clustered in the Acropolis of Lipari and the surrounding "borghi", while in the other districts of Lipari and on the other islands, only farming activities occurred [Giacomantonio, 2010]. Indeed, the minor islands were supposed to be uninhabited to avoid footholds for pirates. Despite the prohibitions, little communities lived on Salina, Stromboli, Panarea and Filicudi. Some documents dated to the end of $16^{\text {th }}$ century, speak about the kidnapping of Aeolian (Stromboli, Panarea and Lipari) farmers by the "Barbareschi" pirates.

In 1598 AD, Mons. Vidal became bishop of Lipari and, during the first years of the 1600s, promoted the building of little churches to encourage the formation of new stable communities. In $1615 \mathrm{AD}$ a chapel dedicated to San Vincenzo Ferreri was built on the island of Stromboli, but it was soon abandoned because the island was only sporadically frequented and threatened by the Turkish pirates [Giacomantonio, 2010].

\subsection{2 $18^{\text {th }}$ century}

In 1696 AD, Bishop Girolamo Ventimiglia, after his visitation of the archipelago, wrote a letter to the Pope describing the social context of the islands. On Lipari, he stated, lived about ten thousand people, most of them living in poverty. He also reported the presence of people on the other islands but, beyond Salina, he highlighted the absence of a church. The Bishop stimulated Liparian people to colonize the minor islands; on Stromboli the first colonists arrived in $1702 \mathrm{AD}$ and they settled in Ginostra, on the south side of the island, less exposed to pirate raids. The policy of Ventimiglia improved the economy of the archipelago; in $1705 \mathrm{AD}$ he wrote about the growth of tax income and his project to build a church on the island of Stromboli, where the fertility of the soils and the position of the island were attracting new settlers [Giacomantonio, 2010]. 
In $1725 \mathrm{AD}$, a document written by the Bishop Platamone referred to the presence of churches on Panarea and Filicudi while the church of San Vincenzo, in the north side of Stromboli, was built in 1730 AD [Giacomantonio, 2010].

\subsection{3 $19^{\text {th }}$ century}

Thanks to wine production and export (see § 3.5.3), the first half of $19^{\text {th }}$ century was a period of great economic improvement for the Aeolian archipelago, and the writings of the travellers that reached the islands during the period offer a clear picture of Stromboli as a dynamic and active centre.

Elpis Melena described Stromboli in her book Blick auf Calabrien und die Liparischen Inseln im Jahre 1860 in which she reported about her journey in the Aeolians. She wrote that 400-550 people lived on Stromboli and that the principal economic activity was grape cultivation.

In 1880, at the end of his pastoral visit, Mons. Natoli described the villages of the archipelago stating that only Lipari could be considered a proper city, while on the other islands people lived in little villages. The most important of those villages were Santa Marina on Salina and San Vincenzo on Stromboli [Giacomantonio, 2010]. The importance of the village of Stromboli was further underlined by Mario Lojacono who visited the Archipelago in 1878. He provided an assessment of the number of inhabitants and Stromboli, among minor islands, turned out to be the most populated [Giacomantonio, 2010], reaching almost 3000 people. By the end of the century the fleet of Stromboli counted more than 50 boats, signifying the economic development the island had.

\subsection{4 $20^{\text {th }}$ century}

In 1891 on the island of Stromboli lived 2716 people [Pitto, 1990], probably the highest number of inhabitants ever reached. The beginning of the $20^{\text {th }}$ century, indeed, was a period of economic recession for the archipelago: the "fillossera" (see § 3.5.3) stopped the wine production and the strategic role of the archipelago along the commercial routes diminished due to the diffusion of steam engine boats and the railways on the Southern Tyrrhenian coast. Emigration became a solution for many people living on the island, a phenomenon pertaining particularly to Stromboli. In 1911 there were about 2,500 inhabitants, 1,100 in 1931, 659 in 1951 and 400 in 1971 (Figure 9).
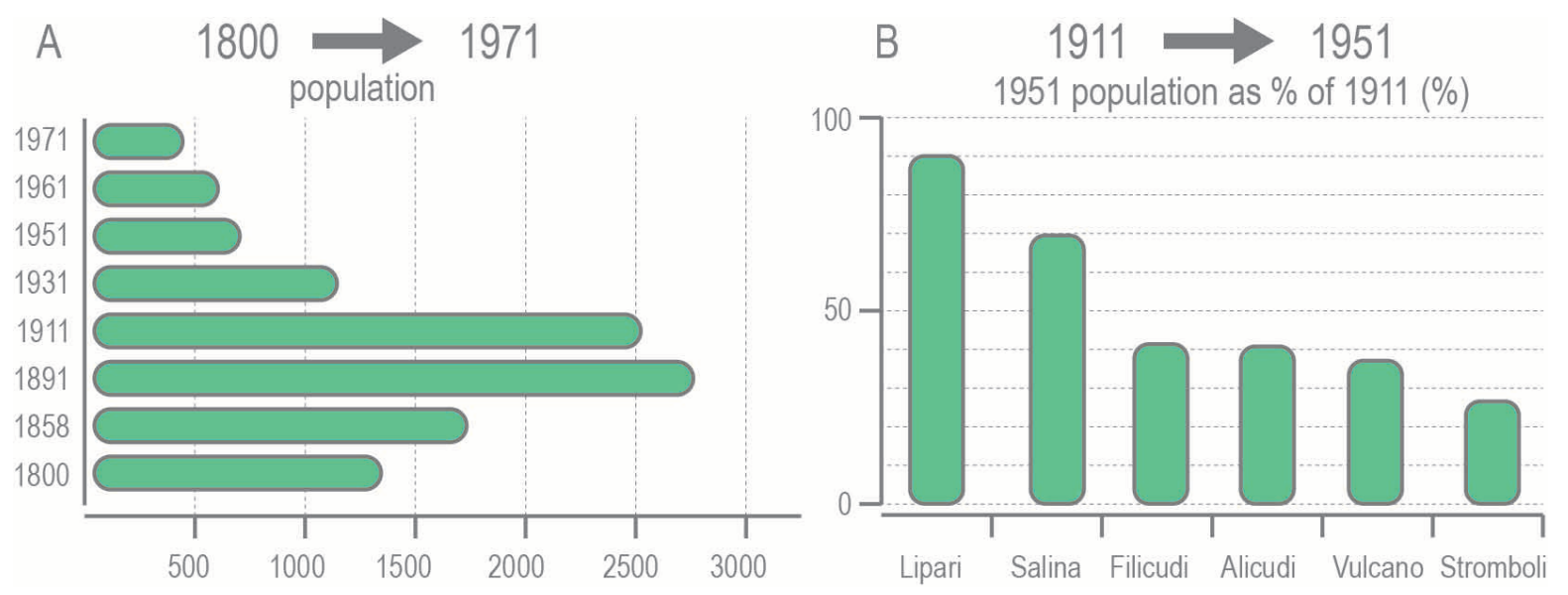

Figure 9. A: Population of the island of Stromboli from 1800 to 1971 and B: the decreasing trend of population in six out of the seven islands of the the Archipelago from 1911 to 1951.

Population decrease did not affect all the islands in the same way (Figure 9). People leaving were mostly from minor islands, especially from Stromboli where the population of 1951 was only $26 \%$ of the number of inhabitants registered in 1911. This latter observation is particularly meaningful because Stromboli was, among the minor islands, 


\section{Andrea Di Renzoni et al.}

the most prosperous. The first half of the XX century was a period of intense activity of the volcano of Stromboli. On May the $22^{\text {nd }} 1919$ an eruption caused the death of 4 people and the destruction of some houses in Ginostra and San Vincenzo; on September the $11^{\text {th }} 1930$, the most powerful eruption of historical times caused the death of 6 people and much damage in the north-western part of the island. Intense volcanic activity is registered during the 1940s, in 1941, 1943, 1944, 1949 and 1950, when only 651 people were living on the island.

Another phenomenon influenced the population dynamics of the $20^{\text {th }}$ century: emigration to Australia and the USA. The loss of population that affected the Aeolian Islands, clearly shown in Figure 9, is coherent with the data for all of Sicily island: the highest number of expatriations is recorded during the first twenty years of the century and in 1931 data show a negative growth of Sicilian population (ISTAT historical data). Many Aeolian people emigrated to Australia (Figure 10); probably the first immigrants from Italy to Australia were missionaries and fisherman from the Aeolian Islands [Reina, 1977], who arrived in the $19^{\text {th }}$ century. Immigrants from Italy attracted relatives and people of their community of origin so that Macdonald, in his report, describes Aeolian emigration as chain migration [Fazio, 2008 and references therein].

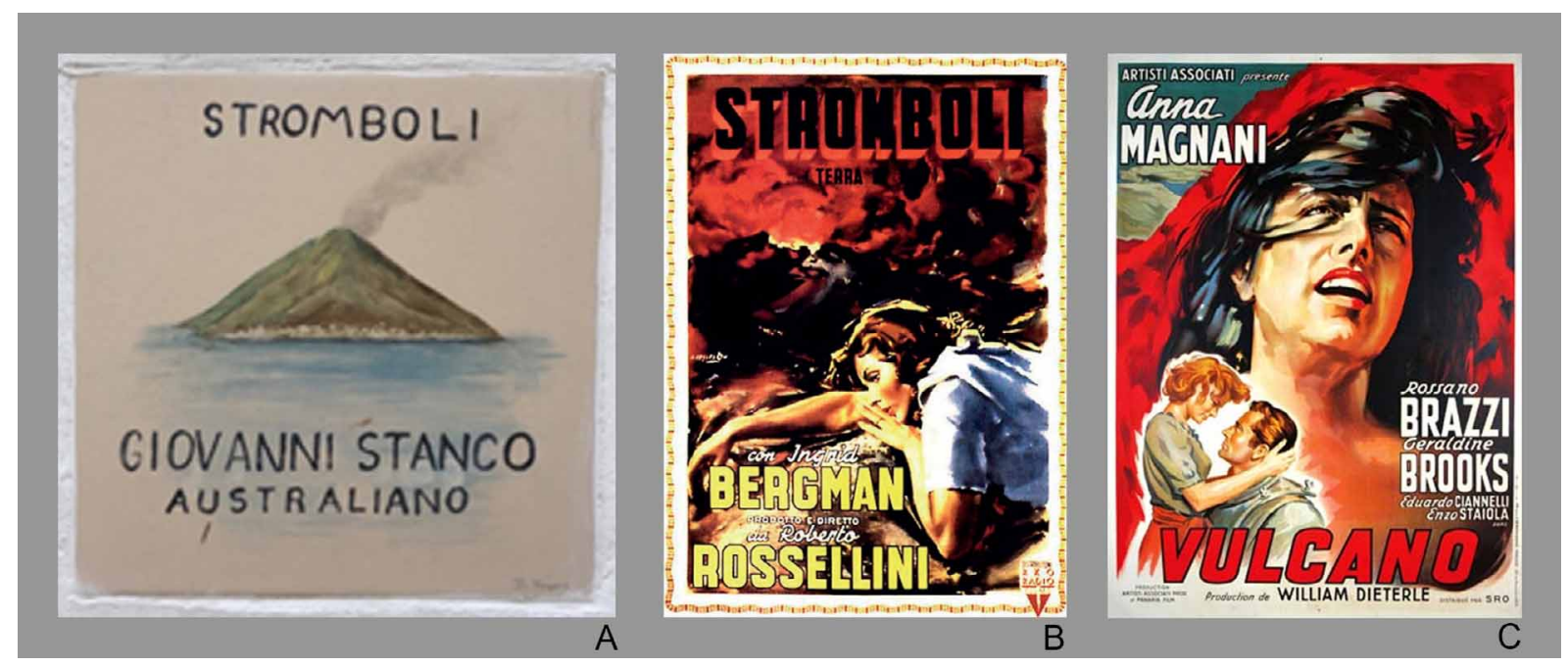

Figure 10. A: The houses of the contemporary village are often marked with tiles; here an example of the strong connection between Stromboli and Australia; B: Poster of the film "Stromboli, Terra di Dio"; C: Poster of the film Vulcano.

In the middle of the $20^{\text {th }}$ century tourism started to be exploited as a new economic resource. Volcanoes attracted tourists since the beginning of the century, as can be inferred by the writings of Luigi Vittorio Bertarelli (Italian Touring Club) who in 1909 met in Stromboli foreign scholars visiting the island [Giacomantonio, 2010], but it was only after the Second World War that a broad touristic interest, mainly linked to the volcanoes, reached the Archipelago. In 1950 Vulcano and Stromboli were chosen as the settings of two movies: "Stromboli, Terra di Dio" and "Vulcano" (Figure 10). The movie "Stromboli, Terra di Dio" (1950) was directed by Roberto Rossellini and starring Ingrid Bergman. In the same year William Dieterle directed “Vulcano", starring Anna Magnani who was engaged to Rossellini. The well-known events among Rossellini, Magnani and Bergman gave a wide notoriety to the movies and the islands. "The War of the Volcanoes", a 2012 documentary film directed by F. Patierno detailed the filming of the two movies. These two islands were the first to attract many tourists: the fumaroles of Vulcano and the volcanic activity of Stromboli fascinated scientists but also a less cultured public. In 1949, the volcanologist Hourun Tazieff showed some shots of the two islands, triggering the association "Connaissance du Monde" to organize "corisière des volcans", a voyage of discovery of the Italian volcanoes. The island of Vulcano was chosen as the place to stay while visiting the Archipelago. From 1950 to 1958, thanks to the French association, many foreign tourists visited the Aeolian Islands. During the same period, the organization "Corda frates" of the University of Messina organized educational tours to Vulcano and Stromboli, attracting many students from northern Italy and Europe. The University of Catania arranged a laboratory on Stromboli, and the "Club Alpino" (Alpine Club of Italy) opened a lodge on the same island. 
The increasing number of tourists and students was a strong impetus to build new accommodation facilities or to restore the houses left by people who emigrated, a phenomenon that involved Lipari, Vulcano, Stromboli and Panarea. From 1949 to 1974 the number of the accommodation facilities grew exponentially.

During the '60s a new kind of tourism interested the Archipelago. The economic boom that Italy was experiencing encouraged the urban upper-middle-class to buy houses in pleasant localities, and the Aeolian Islands were chosen by many of them, who acquired the old houses left years before. An evaluation of the tourist flow at the beginning of the '80s indicates that three islands attracted almost $90 \%$ of the tourists: Lipari (50\%), Vulcano (25\%) and Stromboli (13\%) [Giacomantonio, 2010], while Filicudi and Alicudi, because of their position, were almost excluded from the touristic business.

Since that moment, the communities living on the island deeply changed, mainly shaped by the demands of the tourists. The Stromboli episode in the movie Caro Diario (1993) by Nanni Moretti well represents the international presence of tourists and the total shift in attitude about climbing the volcano. In Moretti's film several tourists are sitting and making small talk perfectly at ease very close to the craters.

\section{The social meaning of volcanoes}

The influence that volcanoes exercise on the people living nearby, in our case simply perceivable by the attention given to the Aeolian Islands by tourists, has a long history and it seems to be common to different cultures all over the world. The relationship between humans and volcanoes is better readable in the wider framework of the relationship between humans and nature, perceived as threatening and nourishing at the same time. Religious beliefs, cultural behaviour, and the characteristics of the social systems of the communities living in volcanic areas are evident manifestations of this attitude.

\subsection{Volcanoes: words, myths, religion, and cultural systems}

The origin of the Italian word "vulcano" is not simple to retrace. We do not know the generic name for volcanos used in antiquity [Becatti, 2010]. Volcanic phenomena were described with careful descriptions, but a specific term to indicate them was never used [Becatti, 2010], and probably single volcanoes were referred to by their proper names, their locations, or by a description of their behaviour [Chester et al., 2000].

Today we define an ignivomous mountain using the name of the Latin divinity Vulcan. He was the god of fire, usually seen as a constructive craftsman. Although Vulcan was later equated to the Greek god Hephaestus, his roots do not appear to be found in either the Greek or Latin languages; instead, it appears to have early Italic, probably Etruscan, origins. Etruscan gods of fire were Velchans and Sethlans, the former primarily a god of destructive fire, the latter associated with the productive use of fire and more often equated with Roman Vulcan by many scholars [Chester et al., 2000].

The passage from a specific term, indicating a deity and/or specific place, to a generic term indicating the natural phenomenon took place in the Arab cultural context [Becatti, 2010] where the word Burkan was used to describe specific geographic aspects of the phenomenon, that later became a noun extending the meaning of an attribute of the proper name from which it derived.

It is worth noting that the name of the deity from which the modern term derives is associated with the productive use of fire (Hephaestus was the craftsman who built the thunder used by Zeus to control gods and mortals), and how, at least in the Italic world, the duality of the phenomenon (positive and negative) was represented by two deities (cf Velchans and Sethlans). No less important is the personification of the volcanoes, proved by the absence of a generic term in antiquity and by the partial overlapping of the Arab term Burkan and mountain. Volcanoes were an important landmark whose presence characterized a landscape with their astonishing manifestations.

The peculiarities that the word "volcano" has in the Western world are rooted in a wider framework that involves the relationship between humans and nature. Myths and religious beliefs have often been evoked to explain natural phenomena, especially those manifested violently, and anthropomorphism has always played a crucial role building those narratives. Anthropomorphism is the assigning of human qualities and behaviours (such as consciousness and 


\section{Andrea Di Renzoni et al.}

complex social emotions) to inanimate objects, animals, or natural phenomena; it is recognizable in almost all cultures and has been documented for centuries [Norenzayan et al., 2008]. Volcanoes, among the more threatening and astonishing natural manifestations, have often been equated to deities or treated as the place where deities live, and therefore indicated with a proper name and believed to have, like humans, a good and a bad side. Furthermore, their behaviour is often held to be driven by emotions as the response to human behaviours.

In Javanese mental representations, the words "mountain" and "volcano" are not automatically dissociated [Lavigne et al., 2008]. There, the world perception is centred on volcanoes that are clearly felt as having a dual nature. In the wayang kulit, a traditional puppet-shadow-play (an ancient form of storytelling), an important character, representing an imaginary mountain (or volcano), is Gunungan (mountain) or Kayon (tree). The Tree of Life symbolizes the nourishing mountain, which feeds the plants and the villagers; the other face is symbolized by fire, flames, and lava, coming out from the volcano's mouth and representing destruction and death. Both faces of the volcano (good and bad) are represented by the Javanese and Indonesian word korban, which means "victim" and "sacrifice" [Lavigne et al., 2008].

The cultural system of the people living around Mount Bromo, on Java Island, is inspired by the volcano as central symbol and deity [Bachri et al., 2015]. Even today the volcano is seen as a source of benefits and its eruptions as a "gift of God" [Bachri et al., 2015], while their negative outcomes are perceived as the punishment of the god reacting to human behaviour. In the Hawaiian tradition, Mount Kilauea is believed to be the abode of Pele, a deity with consciousness and emotions. A complex oral tradition has been built centred on the figure of Pele describing volcanic events [Swanson, 2008]. Mount Fuji is the most famous volcano of Japan, and still today it has a great influence on Japanese people. One of the earliest poems of the Japanese language describes Mount Fuji as follows: "No words may tell of it / No name know I that is fit for it / But a wondrous deity it surely is! / It is the peace giver, it is the god, it is the treasure. / On the peak of Fuji, in the land of the Suruga / I never weary of gazing" [Sigurdsson and Lopes-Gautier, 2007]. Native Americans of the Pacific coast of the USA held that Mount Shasta in northern California was the abode of the spirit chief Skell. The physical power and beauty of the volcano make it a credible gateway to mystical realms, as seen in the number of non-traditional religions, cults, and sects that it attracts today [Sigurdsson and Lopes-Gautier, 2007].

\section{2 volcanoes and material culture: "volcano-centred communities"}

This brief and incomplete review demonstrates how volcanoes, rather than dangerous places to face, and beyond the productive aspect due to the fertility of volcanic soils and the exploitation of volcanic products, are a powerful force in shaping cultural identity [Bachri et al., 2015].

Volcanoes have always exercised fascination over humans. The first known manifestation of the allure of the volcanoes dates to $7^{\text {th }}$ millennium BCE, with the extraordinary wall-painting found at Catalhöyük (Turkey) on the $\mathrm{N}$ and E wall of "shrine" 14, of excavation level VII, in the early 1960s by James Mellaart (Figure 11.a). The lowest register of the painting shows a pattern of 80 squared shapes, while the upper is an irregular figure, filled by dots, with a concave higher profile depicting two peaks, one of which is surrounded by irregular lines and sparse dots. Two interpretations have been proposed: 1 ) the representation of a landscape in which the village of Catalhöyük (the square-shaped pattern) is in the foreground and an erupting volcano (the two peaks), identified as the Hasan Dağı, located ca. $130 \mathrm{~km} \mathrm{NE}$ of the settlement, is in the background; 2) a leopard skin, without the extremities. Recently, the discovery of traces of an eruption almost contemporaneous to level VII supports the "map" interpretation [Schmitt et al., 2014]. It confirms dating to the $7^{\text {th }}$ millennium BCE the first representation of the fascination that volcanoes work on humans.

Even if this extraordinary finding is thought to be the oldest depiction of a volcanic event, recently a similar interpretation has been proposed for some signs from the Chauvet-Pont d'Arc Cave (Ardèche, France; Figure 11.c), a site that provides one of the earliest and most significant manifestations of prehistoric art. There, the depicted subjects are mainly animals, both "classical animals" like horse, bison, megaloceros etc., and "dangerous animals" like cave lions, mammoths, rhinoceros, which are less frequent in Upper Palaeolithic iconography from Western Europe. Figurative elements come together with abstract compositions, some of them unique to the cave. Among the latter, some signs, composed of two diverging arrays of curved lines, have been found in five different panels of the cave, and a dating between 36.7 and $34.1 \mathrm{ka}$ cal BP has been proposed. Recent research on the Bas-Vivarais, a 
volcano located $35 \mathrm{~km} \mathrm{NW}$ of the cave, has recognized volcanic activity in the same period as the painting of the signs, suggesting the hypothesis that humans are likely to have witnessed one or several eruptions and depicted them using these complex signs [Nomade et al., 2016].

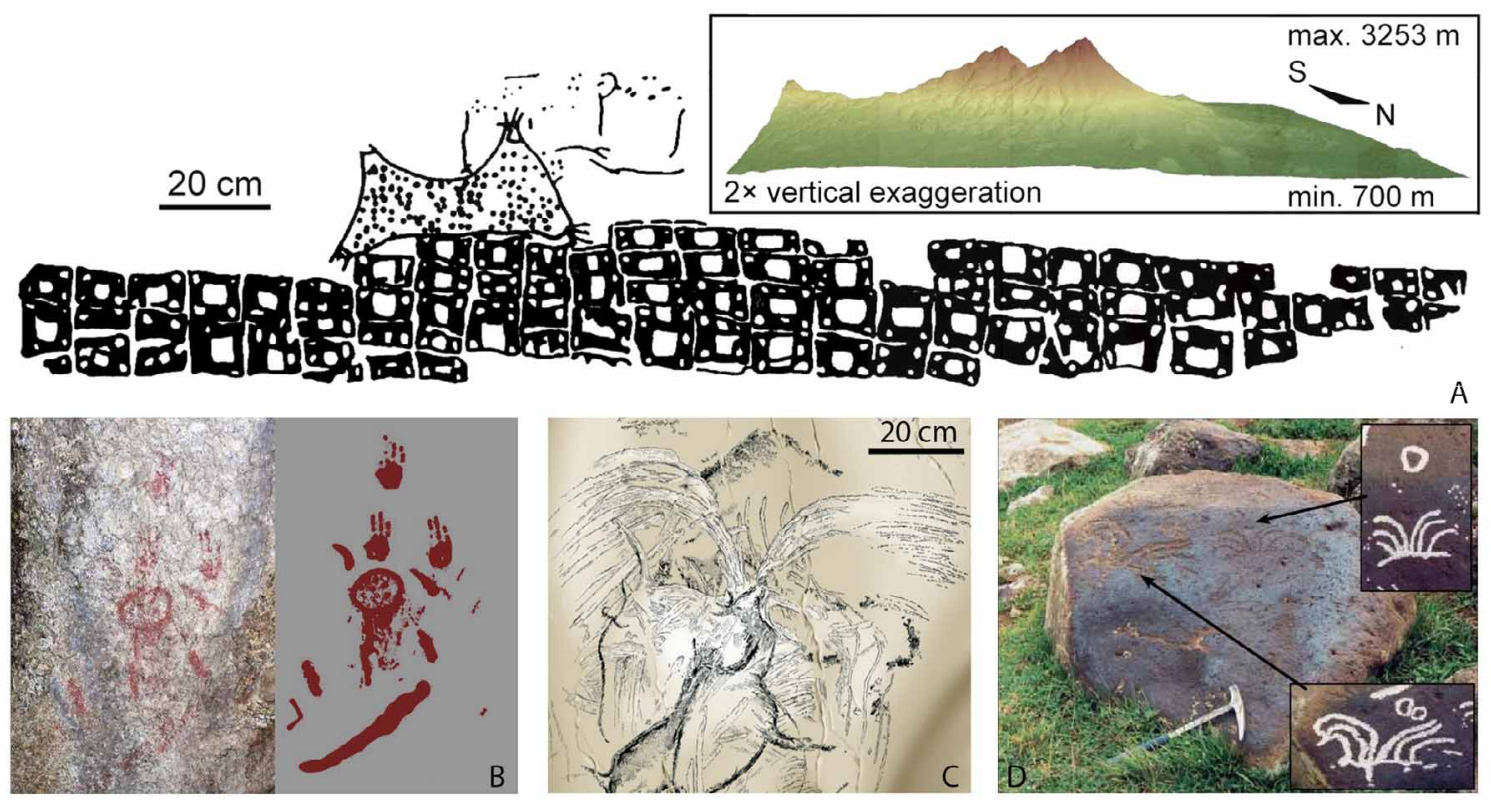

Figure 11. Prehistoric volcano representations. A: Çatalhöyük wall painting and the profile of the Hasan Dağı volcano (after Schmitt et al. [2014]); B: Bronze Age depiction of the erupting Çakallar (after Ulusoy et al. [2019]); C: depicted signs representing volcanoes from Chauvet-Pont d'Arc Cave (after Nomade et al. [2016]); D: Petrogliph depicting the Porak Volcano, in Armenia (after Meliksetian [2013]).

Similar signs were found carved on stones, $9 \mathrm{~km}$ from the Porak volcano, in the Syunik region of Armenia (Figure 11.d). The six petroglyphs are composed by two set of curved lines and rounded figures. In this case also they have been interpreted as the depiction of a volcanic event, dated to the $5^{\text {th }}$ millennium BCE, according to the obsidian tools found near the stones [Karakhanian et al., 2002].

A study published in 2019 [Ulusoy et al., 2019], proposes a new dating, based on two independent rock dating methods, for the Kula footprint, the trace of a human's walk left in hydrovolcanic ash, found in 1968 near Çakallar volcano (Kula, western Turkey, Figure 11b). Traces indicate that more than one individual and an animal (Canis species), hiked the volcano after eruption during the Bronze Age, as the dating to ca 4.7ka of the traces suggests. Approximately $2 \mathrm{~km}$ from the footprint site, a long-known pictograph was interpreted in 2008 as a prehistoric depiction of the erupting Çakallar cone [Akdeniz, 2011]. The volcanologically consistent details in the painting led some authors to hypothesize that Bronze Age eyewitnesses of the eruption also generated the rock art. Although the narrative proposed needs more data to be fully accepted, it is intriguing that Bronze Age people, probably pushed by curiosity and fascination, went toward the vent location immediately after the eruption.

These ancient material manifestations demonstrate how humans have always experienced the volcano's fascination and how the identities of communities living near volcanoes are often shaped by their presence. But this appears not to be the case for the Aeolian Islands, at least during antiquity. Although knowledge of the various aspects of Aeolian material culture over time is far from complete, some considerations can be drawn. For the Early Bronze Age (Capo Graziano facies), pottery decoration indicates a shared style, strongly influenced by the marine landscape of the archipelago which has been interpreted as expressing the identity of the people living in the archipelago [Levi et al., 2020]. Following this hypothesis, it was the sea and the insularity that most influenced people, although it cannot be excluded that volcanoes had an important role in the oral tradition or in other intangible aspects of the island cultural system, as the supposed cult place of Calcara (at Panarea) contribute to 


\section{Andrea Di Renzoni et al.}

demonstrate. It is worth to note that similar incised decorative styles are testified in other coeval archaeological contexts of Greece, thought to be the origin of the Aeolian models (see § 4.2.1.2). Even if the similarities between Greek and Aeolian finds are evident, Capo Graziano style appear much more linked to the maritime sphere.

Volcanoes left their trace in Aeolian material culture starting from the end of the $5^{\text {th }}$ century BCE when Lipari began minting coins, thus exhibiting its economic and political independence. On the coins were often impressed the figure of Hephaestus (the head in the first series or the entire seated figure in the following) [Martinelli and Mastelloni, 2015], chosen as the symbol of the whole archipelago.

As stated before, the attention paid by tourists to the archipelago (see § 4.5.4) entailed a deep change in the social fabric of the islands [Pitto, 1990], especially on the smaller ones. The composition of the resident communities became more heterogeneous, attracting people from outside who choose to live on the islands, at least for a long part of the year. This is particularly true for Stromboli where the volcano gave a strong impetus to new business but, at the same time, became the common element shared among new and old members of the community. Its presence has been felt as benevolent; people refer to the volcano using a proper name as it were a person: "Iddu", a dialectal word for the pronoun "he". People often talk about the "energy of the volcano", and they are sure they can understand its "language" made of noises and smoke. The volcano permeates many spheres of the Strombolian material world: its image is a commercial brand, a means to refer to the island and a symbol of identity. Commercial activities, not only those directly connected to the volcano such as the volcanic guide services, recall the image or the name of Iddu; the same is true for the various cultural initiatives, such as cultural associations or festivals centred on the island, that use a picture of the volcano in their logos. The "volcanic iconography" has its importance also in the private sphere. It is not rare to see tattoos (Figure 12) depicting the silhouette of "Iddu", eternising the closeness between the person and the island, represented by the volcano.

The distinctiveness of the places is another important element in analysing the human-volcano system. Stromboli, like many similar places, is seen to be on the opposite side with respect to cities in a dichotomy of natural and human-built environments: cities are polluted, dirty, crowded and anxiogenic; Stromboli is clean, healthy, and relaxing. The quality of life is perceived to be much higher than in other places, and this better setting should encourage better behaviours (Figure 12). People from outside have often been impressed by the way of living on the island. Mario Lojacono, who visited the archipelago in 1878, highlighted how islands were free from crime and a place in which life was much better than it was in the city [Giacomantonio, 2010]. Some years later Bertarelli described Stromboli as a place where people are welcoming and "have nothing to hide" [Giacomantonio, 2010]. This feeling of safety is rooted in the certainty of the social cohesion driven by the peculiarities of the place, and it is strongly perceived still today.

The framework described demonstrates how complex the human-volcano system is, and how different factors play an important role evaluating the risk of living under an active volcano.

\section{Risk assessment and risk perception}

Risk has been defined as a compound measure of the probability and magnitude of adverse effects [Lowrance, 1980]. Following these definitions, risk appears to be intimately related to judgment and decision-making capabilities. Coping with risk, in the end, is making choices and, hopefully, the right ones.

Choices entail a series of alternatives and the analysis of their outcomes, trying to find a balance between benefits and costs (expressed according to different units of measure). The balance is what is considered safe enough [Starr, 1969] and roughly corresponds to the outcome of the chosen alternative.

A well-known theory used to drive the decision-making process under risk is the maximization of expected utility, whose objective is to provide a rationale for making wise decisions, selecting the alternative that offers the highest expected utility, as in its general formal description by Savage [Holton, 2004]. A criticism to the theory was offered by Simon in 1959, when he stated that when perception and cognition intervene between the decision-maker and his objective environment, the model no longer proves adequate [Simon, 1959].

Sociological and anthropological studies demonstrate that perception and acceptance of risk have their roots in social and cultural factors [Short, 1984]. Furthermore, psychological research on risk perception has led to the discovery of a set of mental strategies, or heuristics, that people employ to make sense of an uncertain world [Kahneman et al., 1982; Johnson and Levine, 2009 and reference therein]. They lie in the opposition between 

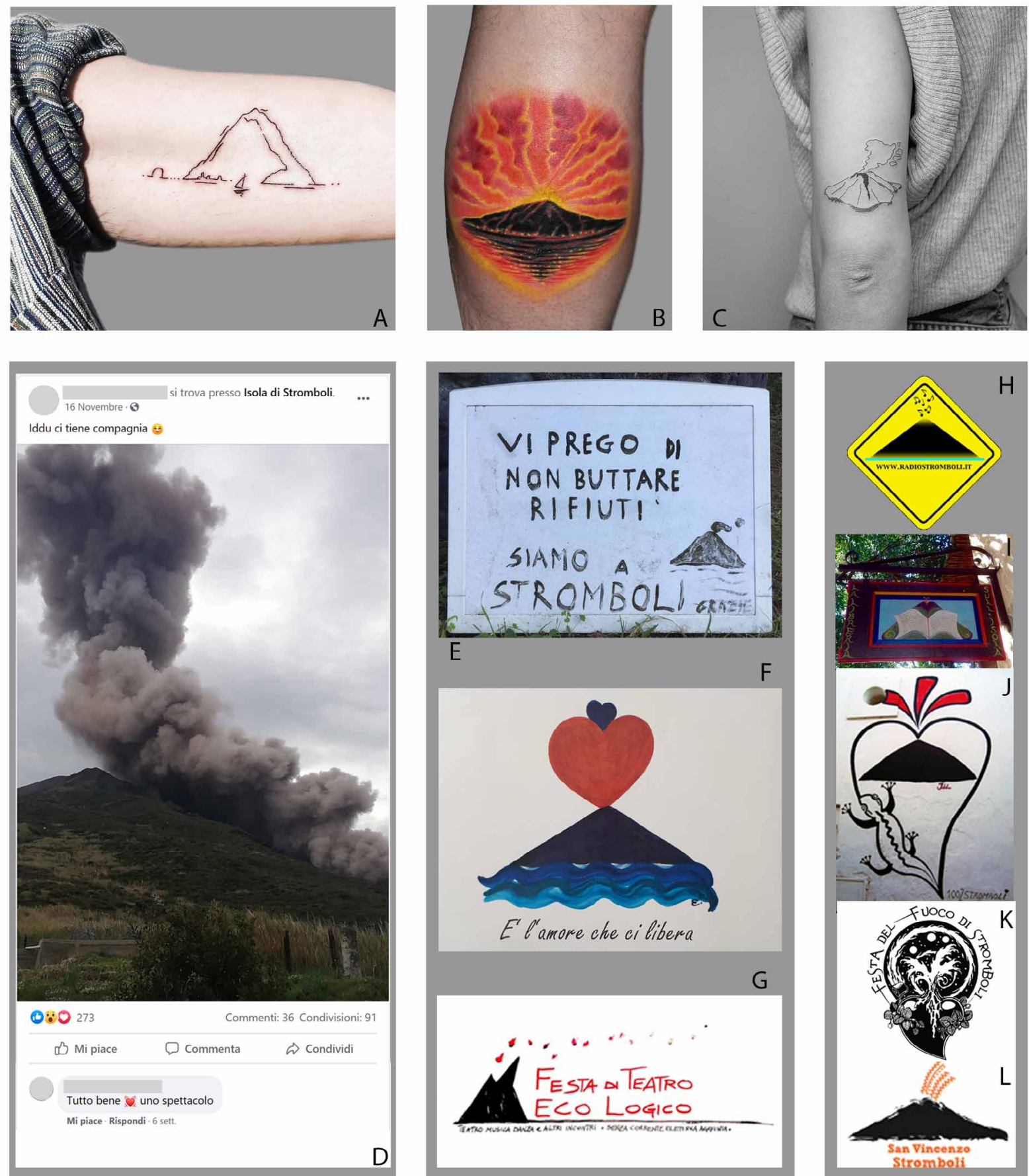

Figure 12. Volcanoes and social identity. A - C: tattoos depicting "Iddu"; D: a social media post where the volcano is described by the mean of human traits (the volcano "keeps us company"); E: signs put in front of a house gate: "do not throw litter, please. We are on Stromboli", an example of the perceived respect that a place like Stromboli (more than others) deserves; F - L: the silhouette of the volcano used as logos (e.g. in postcards), to be noticed the Teatro EcoLogico festival, hold every year on the islands, its name underlines the importance of the "uncontamination" that the place has, and the recurrent association of the volcano with hearth. 


\section{Andrea Di Renzoni et al.}

long-term, uncertain, and hypothetical threats and everyday needs and people's desires. Some of these rules are particularly powerful at influencing people's behaviour and, although they have a certain validity in some circumstances, in others they lead to large and persistent biases, with serious implications for risk assessment [Slovic, 1987].

The above-mentioned factors influence risk perceptions, a conceptually important feature for examining how people understand threats and protect against them [Perry and Lindell, 2008].

\subsection{Heuristics}

The cognitive processes that influence the perception and acceptance of risk include various aspects of human experience, related both to the behaviour of the single individual and to the individual's involvement in society.

People acting within social groups often downplay certain risks and emphasize others as a means of maintaining and controlling the group [Douglas and Wildavsky, 1982]. In addition, it is proven that even in randomly and arbitrarily formed groups, people tend to a more favourable evaluation of their own group's members while disparaging members of other groups [Johnson and Levine, 2009]. It is also clear how response to hazards is mediated by social influences transmitted by friends, family, fellow workers, and respected public officials.

Generally, risks from voluntary activities (where the individual uses his own value system to evaluate his experiences) are more easily accepted than those arising from involuntary hazards (where the criteria and options are determined not by the individuals affected but by a controlling body), beyond any possible cost-benefit evaluation [Starr, 1969]. Hazards judged to be voluntary tend also to be judged as controllable.

People tend to have a misrepresented idea about their abilities (positive illusion bias), their control over events, and of the future. This leads to overconfidence about their vulnerability to risk, and therefore to downplaying the probability of being personally affected by dangerous events. Close to that tendency is the attitude people have to select and distort conflicting information (cognitive dissonance), so that the chosen narrative coincides with preferred or pre-existing ideas. It generates the incapacity to bring together the perceived safety in their everyday lives with information about dangerous scenarios forecast by scientists or technicians. The latter are often rejected or distorted as discordant information. New evidence is perceived as reliable and informative only if consistent with one's initial beliefs; otherwise, it tends to be dismissed as unreliable or erroneous [Nisbett and Ross, 1980]. These attitudes are rooted in people's aversion to change (status quo bias), which makes difficult the adoption of appropriate actions that imply change in their daily routines [Samuelson and Zeckhauser, 1988], and they are justified by the tendencies to attribute the behaviour of others to personality or intentions and, on the contrary, their own behaviour to causes such as limited choices, necessity or competing concerns (fundamental attribution error).

The understanding of probabilistic processes and the estimation of probability and frequency are biased by some cognitive strategies which allow people to reduce these difficult tasks to simpler judgments [Slovicet al., 2000]. Very often the probability of an event is evaluated by the ease with which exemplars of an event can be recalled, because it is believed that instances of frequent events are easier to recall than instances of less frequent ones. But availability is also affected by recency, emotional saliency, and other factors, unrelated to actual frequency. The mere repeated exposure to a stimulus is a sufficient condition for the enhancement of one's attitude toward it. It follows that individuals prefer stimuli that are familiar and predictable. Lastly, people coping with probability tend also to overgeneralize on the basis of small samples of evidence. More generally, difficulties in understanding probabilistic processes that underlie personal experiences cause uncertainty to be denied and risks to be misjudged (sometimes overestimated and sometimes underestimated).

Decision making facing a threat is therefore closely related to the way the same threat is perceived or, more radically, it is based on what is perceived as a threat. Indeed, studies about the heuristics people use have shown that perceived risk is somehow quantifiable and predictable but have also shown that the concept of "risk" means different things to different people [Slovic, 1987]. Only once a risk is perceived will an individual start on the process of decision making, and further, as different people have different perceptions of the same objective environment, they will decide on different levels of behavioural adjustments or adaptations [Burton et al., 2005]. 


\subsection{Risk perception and Volcanoes}

Perception of risk has a prominent role also in the analysis of the human-volcano system, where it has long been discussed, most often as a factor influencing risk assessment, risk preparedness and response to catastrophic events [Gaillard, 2008 and references therein]. Two volumes of the Journal of Volcanology and Geothermal Research were published, one focusing strictly on risk perception ("Volcanic risk perception and beyond" edited by Gaillard and Dibben [2008]), the second addressed to "Volcanoes and Human History" (edited by Cashman and Giordano [2008]), where the perception of risk plays a similarly important role. The literature considers past and present situations, as well as a wide range of geographical, social, and cultural contexts, to trace a series of common and meaningful traits.

It emerges that, when addressing volcanic hazards and responding to volcanic disasters, three aspects seem to be recurrent: 1) the importance of the social context and, more generally, the wider context in which the risk is perceived; 2) the historical development and uniqueness of the places; 3) the intimate relationship between people who live in volcanic environment and volcanoes.

Although generally mentioned in the analysis of risk perception, the role of social constraints has often been highlighted in the publication about perception of volcanic risk. On many occasions, risk awareness has been thought to be most closely related to societal organisation. According to Hewitt [1983] "human awareness of and responses to natural hazards do not depend upon the geophysical conditions, whether their mechanisms, frequency, or past experience of them" but, rather seems to depend on the "ongoing social order, its everyday relations to the habitat and the larger historical circumstances that shape or frustrate these matters". Whatever objective danger may exist, social organizations will emphasize those that reinforce the moral, political, or religious order that holds the group together and therefore individuals actively choose what to fear (and how to fear it), in order to support their way of life. Factors such as material wealth, experience of hazardous events, systems of belief and psychological factors were all important in determining how individuals and social groups responded to extreme events [Chester et al., 1999].

It has been proposed that the reason why people decide to live with continued exposure to considerable hazard, like those living close to Mount Bromo on Java Island, can only be fully understood when investigating within a framework of human-environment systems, and the human-volcano system specifically [Bachri et al., 2015]. There, a complex belief system links the local community with the volcano and an intricate local knowledge of the physical environment facilitates the interpretation of volcanic activity. Further, people feel volcanic eruption as something strengthening social cohesion, reinforcing the existing communal bonds that help recovery [Bachri et al., 2015].

A similar perspective has been used approaching the eruptive events of Mount Merapi, also on Java Island. The volcano, inspiring cultural identity, generates a range of system-reinforcing and capacity-building outcomes. These revolve around social structure as well as grounding through heritage and ancestral lineage. People gain their very place on Earth through the existence of the volcano [Schlehe, 1996].

Another good example emerges from the work of Dibben [2008] focused on Mount Etna (one of the biggest volcanoes in Europe), Italy. The author indicates how the ability of an individual to accept a discernible level of risk lies in their vision or representation of their condition. This representation is moulded not only by their own context but also by their shared social histories [Dibben, 2008].

The importance of cultural, geographical, and historical peculiarities is firmly asserted by Chester et al. [1999]. They support their hypothesis with several examples, stressing the importance, beyond the economic aspects, of the historical development of places. They also add that, "although some general principles of hazard reduction apply to all volcanoes regardless of location, the complex interactions between eruptions, environment, economy and society make all volcanic regions unique" [Chester et al., 1999].

The attachment to place, strengthened by family ties and livelihood, acts in the wider framework of the importance given to contexts. The above-mentioned case of Mount Bromo is only one of the examples showing the importance of that aspect. There, the indigenous communities, whose earliest settlements can be traced back to the $16^{\text {th }}$ century AD, have strong faith in the benevolence of the volcano [Bachri et al., 2015].

In his analysis of Mount Pinatubo (Philippines) communities, Gaillard [2008] convincingly argued that structural constraints rooted in difficulty in accessing resources, and historical and cultural heritage may largely overcome high risk perception in shaping people's behaviour in the face of volcanic hazards [Gaillard, 2008]. He noted how economic factors (such daily livelihoods) were accentuated by the cultural attachment to places: the threat to an individual's identity through a loss of cultural heritage combined with everyday poverty weighed more heavily than the seasonal volcanic hazard. Attachment to place was well perceivable in the banners displayed in 1994 by some of the people 


\section{Andrea Di Renzoni et al.}

who never evacuated Bacolor, the municipality located on the southeast side of Mount Pinatubo, focus of the research: "we are dead and drowned but we will never leave Bacolor" and "because it is my birthplace and because I love it, I will never abandon Bacolor".

Dibben [2008] in the already mentioned paper, goes further when he states that the acceptance of the risk of volcanic activity stems not just from societal marginalisation but can exist in a situation of relative prosperity [Dibben, 2008]. Analysing communities of Mount Etna, he found that risk perception, acceptance and reduction come from a social and cognitive process, rather than a rational evaluation. People often operated strategies to reduce, in their own minds, the risk they were facing [Dibben, 2008]. Also in that context, the human-volcano system seems to play a crucial part: (1) the volcano is perceived as being both a natural wonder and a quite destructive force; (2) it is seen as a resource, particularly because of the natural beauty of the region (touristic attraction); (3) people felt a strong bond with the volcano, and they used words that demonstrate a sort of personal relationship with the volcano, giving it human-like characteristics (a respondant states: "It is with us for better or for worse. It is an important presence in my life).

Other interesting considerations are those emerging from an article about perceived volcanic risk in the community living alongside Vesuvius, published by Barberi et al. [2008]. Using a questionnaire, authors explored the relationship between people and the place where they live. It emerged that people are aware of the risk they are exposed to, but, at same time, volcanic risk is listed as the last problem among those they must cope with [Barberi et al., 2008], thus stressing the importance of daily-life necessities over volcanic risk, thought not to be an imminent threat. Indeed, $45 \%$ think that a future eruption will occur within 10 to 50 years $35 \%$ that an eruption will occur over 50 years from present.

People who choose to live in a hazardous volcanic area are pushed by a combination of several factors. The bond they have with places (economic relations, family-ties, cultural and social constraints) and "day-to-day" needs seem to be (most of the time) predominant and felt as stronger necessities than those imposed by volcanic threats.

Decisions about where a person chooses to live are crucial to the production of volcanic risk and, within this process, volcanic risk awareness plays a relatively unimportant role [Dibben, 2008]. People whose perception is being studied are living in a world constructed from their own concepts (including) the concept of what is hazardous [Short, 1984]. Scientific and "rational" knowledge of the risk is not necessarily a given characteristic for those living in a high-risk area. Risk perception differs from the simple knowledge of the existence and mechanism of a hazard but rather it refers to the likelihood people assign to the possibility that a hazard will affect them. When a decision puts people in an "unexpected" situation of risk, individuals will use various strategies to reduce the feeling of tension aroused by the contrasting information (the actual risk and the outcome of their choices) and tend to search for information that is congruent with their wishes (see cognitive dissonance) and voluntarily contradict scientific information about their environment [Dibben, 2008]. Indeed, research has shown that improved reliability of hazard assessment does not discourage people from taking risks.

Some scholars have focused their attention on explaining the aversion people have to some hazards, their indifference to others, and the discrepancies between these reactions and the opinions of experts [Slovic, 1987]. It is argued that this discrepancy can be recognized, beyond the described attitude people have to risk, also in some characteristics of "scientific analyses of risk" and the range of things they focus on: people's health, but not usually their mental health; people lives, but not usually their lifestyles; the economic well-being in aggregate, but not in individual or distributional terms; the physical environment, but neither the social values associated with it nor ecological scarcity [Short, 1984].

\section{Discussion and final remarks}

The islands of the Aeolian archipelago can be distinguished into main groups based on the potentialities they offer, as described in $\S 3$. In order to compare the values of different parameters, their scores have been normalized according to a scale that spans from 1 to 5 , so that values may be added and a ranking of the island proposed. Normalization has been achieved by dividing the difference between the maximum and minimum value for each parameter for the number of classes; the number so obtained has been used as the bin to assign the score values. The following thresholds have been used to normalize values: (1) for the availability of land slopes under 30 degrees; (2) for ease of access to the island three aspects have been considered: (a) SLPs (see § 3.2.1) defined with a buffer of 40m 
around the bays and inlets; (b) the general roundness of the island and (c) the mean height and slope of the coast within a buffer of $300 \mathrm{~m}$; (3) water availability has been quantified by adding the number of springs multiplied by two and the number of dripping points; (4) geological resources have been quantified by summing the number of different resources an island could offer (obsidians were not been considered for Vulcano because the lava outcrops are recent). In the case of 3 and 4 , a value of zero has been assigned when the specific resource is completely unavailable on an island. Table 4 and Figure 13 shows the results of the value normalization and the ranking of the islands.

\begin{tabular}{|c|c|c|c|c|c|c|}
\hline \multicolumn{7}{|c|}{ Island potentiality } \\
\hline Island & Land & $\mathrm{H}_{2} \mathbf{O}$ & Resources & Coast & Score & Sites \\
\hline Lipari & 5 & 5 & 5 & 5 & 20 & $10(21)$ \\
\hline Vulcano & 3 & 1 & 5 & 5 & 14 & 0 \\
\hline Salina & 3 & 2 & 1 & 3 & 9 & $7(12)$ \\
\hline Panarea & 1 & 1 & 1 & 3 & 6 & $3(8)$ \\
\hline Stromboli & 1 & 2 & 0 & 3 & 6 & $3(6)$ \\
\hline Filicudi & 1 & 1 & 0 & 2 & 4 & $3(5)$ \\
\hline Alicudi & 1 & 0 & 0 & 1 & 2 & $1(1)$ \\
\hline
\end{tabular}

Table 4. Ranking (maximum score: 20) of the Aeolian islands based on their potentiality (see text for explanation). Coasts value is the mean among SLPs (suitable landing points), roundness index, mean height and mean slope. Sites indicate prehistoric evidences on the islands, settlements correspond to numbers without brackets, total number of archaeological sites are reported in brackets.

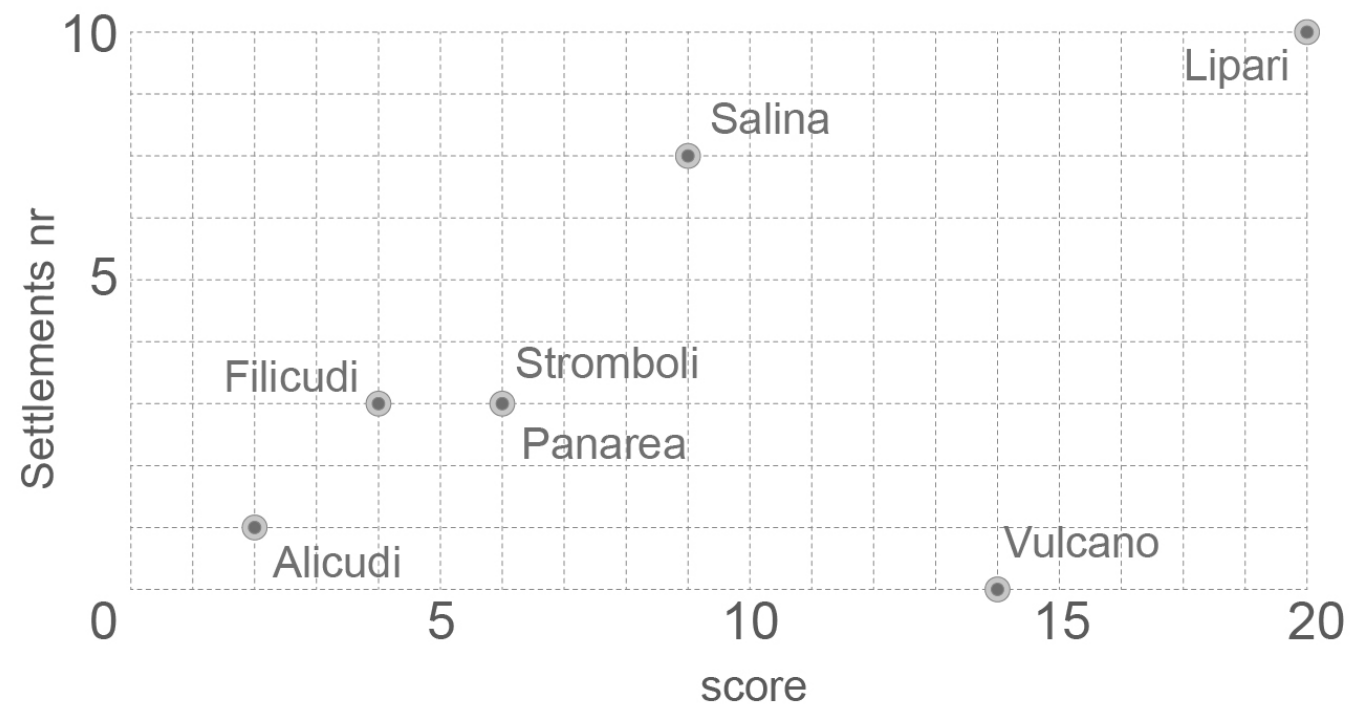

Figure 13. Correlation between settlement numbers and score of the Aeolian islands.

A column reporting numbers of prehistoric settlements (the total number of sites is reported in brackets) recorded for each island has been added [Martinelli and Lo Cascio, 2018; Martinelli et al., 2021], thought to be a good proxy of human presence. Prehistoric communities were strongly linked to the environment and to the potentiality it offers and the relationship between resources and human presence is more clearly perceivable than in other periods where wider economic and social systems intervened. The intensity and duration of 


\section{Andrea Di Renzoni et al.}

volcanic activity may have discouraged human settlement on the island, while, as a generalization, on the other islands, even the most active, number of sites is a function of the resources. The main islands are Lipari and Vulcano with scores of 20 and 14 respectively; Salina can be considered a middle potentiality island with a score of 9; Stromboli, Panarea, Filicudi and Alicudi can be defined as low potentiality islands. Adding an extra score for position (a factor difficult to quantify), assigning to the islands along the routes from the Strait of Messina a higher score, Stromboli and Panarea should be divided from Filicudi and Alicudi. Greatest availability of resources is concentrated at Lipari and Vulcano which, considered as a whole (because of their closeness and historical events), would form the centre of the archipelago. Volcanic resources triggered population increase and the involvement of the archipelago in wide networks during prehistory (see § 3.4.1); they were also of great economic importance for a long period (see § 3.4.2).

The correlation between scores and number of villages (and with the number of archaeological sites in general) is high, with the evident exception of the island of Vulcano where no sites are attested. Although some of the factors that influenced the high score of Vulcano could be related to its recent morphology (till the 1st millennium AD the only large flat area was those of Vulcano Piano, on the central-southern part, while Vulcanello and the area of the modern harbour did not exist), the island offered the same great opportunity to settler. It is in an optimal position, being the closest island to Capo Milazzo (Figure 1) and placed less than a $\mathrm{km}$ from Lipari, the large plain of Vulcano Piano was a very favourable place for farming and livestock. It cannot be excluded that traces of ancient human presence are buried under thick tephra layers but, more likely, the Fossa caldera could have been strongly active. Between the 10th and middle 16th centuries AD La Fossa caldera was the site at Vulcano of at least 19 eruptions [Malaguti et al., 2021]. The only place on the island with low volcanic risk and characterized by favourable morphology is Gelso, on the south coast but, at current knowledge, no archaeological evidence is known.

The island of Stromboli has been populated at least since the $4^{\text {th }}$ millennium BCE and, on present knowledge, only three gaps and a period of very low demographic presence are perceivable: (1) from the second half of the $2^{\text {nd }}$ millennium BCE to the $5^{\text {th }}$ century BCE; (2) between the Roman period and the medieval period; (3) during the period that follows the late Middle Ages to the beginning of the $18^{\text {th }}$ century. More generally, it can be stated that population has not been constant over time, but periods of flourishing alternated with periods of limited human activity (Table 3), despite the difficulty of evaluating the human presence on the island and its intensity. Indeed, archaeological data are the only available source for most of the time span considered, and the lack of systematic research may lead to an underestimation of the human presence in some periods. Only at San Vincenzo, on the north-east edge of Stromboli, have intense investigations been carried out, thus offering the main dataset available. Most of the island is still unexplored and other sites, discovered by chance, are known in different localities, suggesting that other evidence may be yet unknown. Furthermore, recent lava flows may have buried ancient living surfaces, as in the case of the Greek-Roman-period of San Bartolo lava flow, which covered a large sector of the NE lowland and coastal area.

Despite these difficulties, we propose that San Vincenzo may reasonably be considered a good proxy of the population level on the island, mainly because of its position, which is particularly appropriate for human settlement [Di Renzoni et al., 2016a,b]: it offers natural protection and the best field of vision, ensuring control over the body of water that divides the Archipelago from the Calabrian coast (see § 3.5.1); it has a direct control over the best landing point of the island (see § 3.2 ) and it is placed immediately above the largest flat area (see $\S 3.1$ ). It is also close to the known dripping points of the island (see $\S 3.3$ ).

Probably it is not by chance that the most ancient traces of human presence have been discovered there. There is a sporadic presence (see § 5.1.1) immediately after the collapse of the Sciara del Fuoco, an event that marked the end of the Neostromboli phase (see $\S 4.2$ ), during the $4^{\text {th }}$ millennium BCE, which was followed by a period of relatively quiescence of the volcano [Francalanci et al., 2013]. The lack (up to now) of Neolithic evidence is informative: the Diana facies (second half $5^{\text {th }}$ millennium BCE) is the period of maximum exploitation of Liparian obsidian (see § 3.4.1), characterized by a high population, as the number of sites dating to this phase suggests. Vulcano, Stromboli, Alicudi are the islands where Diana sites are not attested. Probably Alicudi was excluded from this Neolithic "expansion" because of its geographical marginality. Volcano was not populated in antiquity due to its volcanic activity, although the potentiality the island offers; the same could be true for Stromboli, since there is evidence of strong volcanic activity until the $5^{\text {th }}$ millennium BCE [Manni et al., 2019].

The Copper Age is thought to be a period of demographic recession, also related to the effect of the collapse 
of the Sciara del Fuoco [Manni et al., 2019], but significantly on Stromboli the three Copper Age phases are attested, the same as on Salina and Lipari (high potentiality islands).

The beginning of the Bronze Age, the Capo Graziano facies, is the only prehistoric period during which the whole Archipelago was occupied and on the main islands, Lipari and Salina, more than one settlement is attested. On Stromboli the large village of San Vincenzo (see § 5.1.2) attests a stable and intense human presence. The village was abandoned during the mid- $2^{\text {nd }}$ millennium BCE, like several other Capo Graziano facies sites of the archipelago. This moment corresponds to the beginning of the first long population-gap on Stromboli, which must be related to a general socio-political trend involving the entire archipelago rather than environmental factors.

The time span that separates Bronze Age occupation from the classical period, when a further period of occupation began, largely corresponds to a phase during which eruption and lava flows did not affect the northern part of the island. The eruption of the San Bartolo lava flow ranges between $360 \mathrm{BCE}$ and $7^{\text {th }}$ century $\mathrm{AD}$ [Speranza et al., 2008, most likely at $100 \mathrm{AD}( \pm 100)$; Arrighi et al., 2004] when, at least at San Vincenzo, human presence is well attested (see § 5.2).

The (apparent?) gap that follows the classical age corresponds to a period of low population levels in the archipelago that is, at least partially, related to the Monte Pilato eruption in Lipari during the $8^{\text {th }}$ century AD. Volcanic activity that strongly involved the community living on the island includes that of the late Middle Ages, which caused the destruction of the little church built in San Vincenzo and triggered a huge tsunami (see § 5.3).

After the abandonment of the medieval church (and plausibly the related hamlet), another gap began: a period of ca 2 centuries during which the human presence was very limited. (Probably Stromboli was never completely abandoned. During the $16^{\text {th }}-17^{\text {th }}$ centuries AD on the island there was not a stable village but people frequented Stromboli for productive purposes only. The same scenario can be proposed for the periods that are not testified by material traces). In that period Stromboli again has its connection to the history of the main island, Lipari (cf the sack of Lipari in 1544 AD by Khair-ed-Din, also known as "Ariadeno il Barbarossa").

Piracy strongly influenced human presence on the minor islands, because of the prohibition by the authorities and fear among the people. This was the reason why, in most recent periods, first groups settled at Ginostra, on the south side of the Stromboli island, even though its potentiality (land, visual landscape, ease of docking) was much lower than San Vincenzo. Indeed, during the period of maximum flourishing of the archipelago, the greatest development was on the north side of the island. The position of the island and its morphology played a crucial role in the $19^{\text {th }}$ century when the wine industry gave a great economic impetus to the archipelago, and Stromboli along with Lipari and Salina were the islands most involved in this activity. Furthermore, at the beginning of the $19^{\text {th }}$ century (during the Continental System), the Southern Tyrrhenian was an important economic space and an important, although fluid, frontier between France and England. In that context Stromboli, the eastern outpost of a Bourbon kingdom, thanks to its strategic position, received an influx of merchandise richer and more varied than it normally received during peacetime, in the absence of the privateer activities [Fazio, 2012].

Data about volcanic activity during this period are very detailed and describe how some paroxysms and major eruptions occurred (Figure 8) when the highest population level was reached. Between 1825 and 1891 Stromboli registered the highest population increase (+63\%, from 1660 to 2716 inhabitants) of the whole archipelago [Fazio, 2008], attracting farmers from Calabria and other minor islands. The fleet of the island counted, in 1871, 52 boats, underlining the importance of maritime activities [Fazio, 2008] that took advantage of the island's location.

The alternation of demographic flourishing and crisis is best outlined in a framework where historical conjunctures either enhanced or diminished the potentiality of the islands, mainly by means of the central entity of Lipari and Vulcano. Potentialities had a major role also with respect to dangers, as the marginality of Filicudi and Alicudi confirms. Marginality varies over time. During the Bronze Age, for example, Filicudi was not a marginal island, here intended as in the long term. Volcanic dangers affected people and livelihoods to a lesser degree than historical contingencies that decreased the outcome of the island potentiality. It is important to note that accurate knowledge of volcanic activity and its impact on the whole Archipelago over the past 1500 years has been recently given for Lipari [Pistolesi et al., 2021] and Vulcano [Malaguti et al., 2021]. The loss of importance of the Southern Tyrrhenian sea and the introduction of steam engine, for example, had an impact much greater than the risk of volcanic activity. In this view, the Stromboli eruptions of 1919 and 1930, which caused 4 and 6 victims respectively, should be framed in the broad historical context, characterised by massive 


\section{Andrea Di Renzoni et al.}

emigration from southern Italy (see § 5.4.4). The highest depopulation rate that affected Stromboli fits in the model we propose: the centre of the archipelago, characterized by the highest potentiality, was affected to a much lesser degree than the small islands; among them Stromboli suffered the highest depopulation because of its former prosperity, reached thanks to conjunctures that over increased some potentiality, constraining social and economic structures and diminishing resilience capacity.

More generally, and especially for the most ancient periods, the temporal scale discrepancy is a problem difficult to avoid when relating human presence and volcanic events. Archaeology and volcanology usually describe processes rather than occurrences whose outcome are not perceivable at the scale of individuals but rather that of societies. Individuals react to inputs they can grasp, events that are bounded in a short span of time ("individual time"); individual strategies, beyond their efficacy, respond to those stimuli but are not triggered by long-term processes whose spans of time ("social time") are too long to be recognized during their development. Responses to a volcanic event, especially in the case of small communities, are best readable in "individual time" and from the perspective of "individual strategies": very often people choose to remain in their village and face volcanic threats or, when evacuated, choose to come back from relocation centers despite the danger they felt [Gaillard, 2008]. This attitude is registered not only in economically less developed societies but also in developed ones, as the paradigmatic case of Harry R. Truman demonstrates. He died refusing to evacuate during the 1980 eruption of Mount St. Helens (Washington, USA) because of his attachment to the place: "I am part of that mountain; the mountain is part of me". The story raised him to heroic stature in the eyes of many, inspiring a folk song and a movie [Cashman and Cronin, 2008]. Individual behaviour changes when facing long-lived volcanic events. As stated, it is probably the case for Vulcano where the frequent and long-lasting eruptions had a profound influence on the choices of human communities. Recently, on the island of Montserrat (Caribbean Sea), the eruption of the Soufrière Hills volcano which had remained quiescent for many centuries initiated in 1994 and continued for more than 15 years, remarkably influencing the life of the island community, part of which definitively abandoned the island [Sword-Daniels et al., 2014].

From the perspective of the evaluations made by individuals choosing to live on the island, it emerges that people have fewer tools to address long-term processes and events that do not affect them directly, while discrete and clearly perceivable occurrences are easily encompassed in personal or social frameworks.

In the $20^{\text {th }}$ century, when tourism (see $\S 5.4 .4$ ) prompted by volcanoes had become the economic driving force of the archipelago, the two components (potentiality and risk bounding) clearly merged. Living on the island implied dependency on the volcano and thus the acceptance, or underestimation, of risk that is achieved by a series of psychological and social strategies (see § 7), and that acts along two main lines: (1) the building of a coherent narrative in which volcanic risks are bounded in an open-risk concept [Bachri et al., 2015] that includes both potential positive and negative outcomes and, closely related to it, (2) the construction of an intimate relationship with the environment. The first concerns how people receive and process information that can be used to estimate the probability of volcanic hazard activity occurring, and it is related to the context of experiences, beliefs and expectations that are forged, changed, and sustained through social relationships among members of the communities, influencing the decision making [Panton et al., 2008]. The narrative always includes the construction of a system where the volcano acquires the capacity to interact with humans. It becomes the central element of a nourishing (offering both economic and spiritual resources) and pure environment that instils a strong attachment to place. Thus, the volcano became an active element shaping social identity (see § 5.1), provided with a great system-strengthening capacity. This phenomenon, better perceivable in observing a living social system rather than in the material remains, is fully recognized in the case of Stromboli in the observation of the volcano pervasiveness (see § 5.2).

Human presence on the island of Stromboli appears to be poorly correlated with the danger of volcanic activity but rather with opportunities that the islands (and "Iddu") offer at times. Periods characterised by the (at least apparent) absence of people can be better understood through the relationship that linked Stromboli with the main island Lipari, centre of the archipelago. While in some cases increased volcanic activity may have triggered a period of abandonment (cf late Middle Age, see § 4.4), they always coincided with long-term social processes that affected the archipelago or the wider region of the Southern Tyrrhenian sea. Probably (and apart from uncommon events of very high magnitude), the fluctuations of population induced by eruptions are too fast to be recognized in the material record and, furthermore, they are often balanced by the described mechanisms of the human-volcano system, often strengthened by the insular envirorment. 


\section{References}

Akdeniz E. (2011). Some evidence on the first known residents of Katakekaumene (Burned Lands). Mediterranean Archaeology and Archaeometry, 11, 1, 69-74.

Arias, C., G. Bigazzi, F. P. Bonadonna, M. Cipollini, J.C. Hadler, C. M. G. Lattes, and G. Radi (1986). Fission-track dating in archaeology: a useful application. Parrini, P. (ed.) Scientific Methodologies Applied to Works of Art. Proceedings of the Symposium, Florence, Italy, 2-5 May 1984. Montedison, Progetto Cultura, Milano, 151-159.

Arrighi, S., M. Rosi, J.C. Tanguy and V. Courtillot (2004). Recent eruptive history of Stromboli (Aeolian Islands, Italy) determined from high-accuracy archeomagnetic dating. Geophys. Res. Lett. 31, 19603.

Arrighi, S., J.C. Tanguy and M. Rosi (2006). Eruptions of the last 2200 years at Vulcano and Vulcanello (Aeolian Islands, Italy) dated by high-accuracy archeomagnetism. Phys. Earth Planet. Int. 159, 225-233.

Bachri, S., J. Stötter, M. Monreal and J. Sartohadi (2015). The calamity of eruptions, or an eruption of benefits? Mt. Bromo human-volcano system a case study of an open-risk perception, Nat. Hazards Earth Syst. Sci., 15, 277290.

Barberi, F, M. Rosi and A. Sodi (1993). Volcanic hazard assessment at Stromboli based on review of historical data. Acta Vulcanol., 3, 173-188.

Barberi, F., M.S. Davis, R. Isaia, R. Nave and T. Ricci (2008), Volcanic risk perception in the Vesuvius population, J. Volcanol. Geotherm. Res. 172, 244-258.

Barnao, E. (2017). Appunti per servire alla storia di Stromboli. Edizioni del Centro di Studi Eoliano.

Becatti, G. (2010) Vulcano, tra il dio e la montagna: il passaggio linguistico dal mito alla scienza. Bollettino Telematico dell'Arte, n. 553.

Beccaluva, L., G. Gabbianelli, F. Lucchini, P. L. Rossi and C. Savelli (1985). Petrology and K/Ar ages of volcanics dredged from the Aeolian seamounts: implications for geodynamic evolution of the Southern Tyrrhenian basin, Earth Planet. Sci. Lett., 74, 187-208.

Bernabò Brea, L. (1985). Gli Eoli e l'inizio dell'età del bronzo nelle isole Eolie e nell'Italia meridionale. Napoli.

Bernabò Brea, L. and M. Cavalier (1960). Melìgunis Lipára I. La stazione preistorica della Contrada Diana e la necropoli protostorica di Lipari. Meligunis Lipara I. Flaccovio, Palermo.

Bernabò Brea, L. and M. Cavalier (1968). Melìgunis Lipára III. Stazioni preistoriche delle Isole di Panarea, Salina e Stromboli. Palermo.

Bernabò Brea, L. and M. Cavalier (1991). Melìgunis Lipára VI. Filicudi. Insediamenti dell'età del Bronzo. Palermo.

Bernabò Brea, L. and M. Cavalier (1995). Meligunìs Lipára VIII - Parte I. Salina. Ricerche archeologiche (1989-1993). Palermo.

Bertagnini, A, A. Di Roberto, M. Pompilio (2011). Paroxysmal activity at Stromboli: lessons from the past, Bull Volcanol., 73, 1229-1243. doi:10.1007/s00445-011-0470-3

Bertagnini, A. and P. Landi (1996). The Secche di Lazzaro Pyroclastics of Stromboli volcano: a phreatomagmatic eruption related to the Sciara del Fuoco sector collapse, Bull Volcanol,. 58, 239- 245.

Bertagnini, A., N. Métrich, P. Landi and M. Rosi (2003). Stromboli volcano (Aeolian Archipelago, Italy): an open window on the deep-feeding system of a steady state basaltic volcano, J. Geophys. Res., 108, 1-15.

Bettelli, M., V. Cannavò, A. Di Renzoni, F. Ferranti, S.T. Levi, M.C. Martinelli, A.M. Mastelloni, N. Ollà, G. Tigano, M. Vidale (2016). L’Età del Bronzo a Stromboli: il villaggio terrazzato di San Vincenzo come avamposto nordorientale dell'arcipelago eoliano. Scienze dell'Antichità, 22, 2, 297-313.

Bevilacqua, A., A. Bertagnini, M. Pompilio, P. Landi, P. Del Carlo, A. Di Roberto, W. Aspinall and A. Neri (2020). Major explosions and paroxysms at Stromboli (Italy): a new historical catalog and temporal models of occurrence with uncertainty quantification, Scientific Reports, 10, 17357. https://doi.org/10.1038/s41598-020-74301-8

Brunelli, D., S.T. Levi, P. Fragnoli, A. Renzulli, P. Santi, E. Paganelli, M.C. Martinelli (2013). Bronze Age pottery from the Aeolian Islands: definition of Temper Compositional Reference Units by an integrated mineralogical and microchemical approach, Applied Phys., A Materials Sci. Proces,. 113, 855-863. DOI:10.1007/s00339-0137775-3.

Burton, I., R.W. Kates and G.F. White (2005). The Environment as Hazard (second edition). The Guilford Press.

Campisano, A., G. D’Amico and C. Modica (2017). Water Saving and Cost Analysis of Large-Scale Implementation of Domestic Rain Water Harvesting in Minor Mediterranean Islands. Water, 9, 12, 916.

Cashman, K.V. and G. Giordano eds. (2008). Volcanoes and human history, J. Volcanol. Geotherm. Res., 176, special 


\section{Andrea Di Renzoni et al.}

issue, 325-483.

Cashman, K.V. and S.J. Cronin (2008,). Welcoming a monster to the world: Myths, oral tradition, and modern societal response to volcanic disasters, J. Volcanol. Geotherm. Res., 176,407-418.

Cavalier M. 1981, Stromboli Villaggio preistorico di San Vincenzo, Sicilia Archeologica nn. 46-47, 27-54.

Cavalier, M. (1979a). Ricerche preistoriche nell'Arcipelago Eoliano, Rivista di Scienze Preistoriche, XXXIV, 1-2, 44-136.

Cavalier, M. (1979b). Necropoli Greca di Stromboli, Sicilia Archeologica, XII, 0, 7-26.

Cavalier, M. (1999). La fondazione della Lipara Cnidia. La colonisation grecque en Méditerranée occidentale. Actes de la rencontre scientifique en hommage à Georges Vallet organisée (Rome-Naples, 15-18 novembre 1995). Collection de l'Ecole française de Rome 251, 293-302.

Cazzella, A. and G. Recchia (2013). Malta, Sicily, Aeolian Islands and Southern Italy during the Bronze Age: The meaning of a changing relationship, in M. E. Alberti and S. Sabatini (eds) Exchange Networks and Local Transformations. Interaction and local change in Europe and the Mediterranean from the Bronze Age to the Iron Age, 80-91.

Cazzella A., G. Recchia (2018). Local networks and Aegean-Mycenaean connectivity in the Tyrrhenian and Adriatic seas, in M. Bettelli, M. Del Freo, G.J. van Wijngaarden (eds.), Mediterranea Itinera. Studies in Honour of Lucia Vagnetti, CNR, Roma, 11-31.

Cazzella, A., M. Gori, M. Pacciarelli and G. Recchia (2020). 2500-2000 BC: connectivity phenomena between the Balkans, Greece, Southern Italy, Eastern Sicily, the Aeolian Islands and Malta. Rivista di Scienze Preistoriche, LXX, S1, 183-197.

Chester, D.K., A.M. Duncan, J.E. Guest, P.A. Johnston and J.J. Smolenaars (2000) Human Response to Etna volcano during the classical period, in W. G. McGuire, D. R. Griffiths, P. L. Hancock, I. S. Stewart (eds) The Archaeology of Geological Catastrophes, Geological Society, London, Special Publications, 171, 179-188.

Daniele, D. (1997). Studio chimico-petrografico e individuazione delle aree di provenienza del materiale lavico delle macine di Entella, Seconde giornate internazionali di studi sull'area elima (Gibellina, 22-26 ottobre 1994), Atti I, Pisa - Gibellina 1997, 465-524.

Del Moro, S., A. Renzulli and M. Tribaudino (2011). Pyrometamorphic processes at the magma hydrothermal system interface of active volcanoes: evidence from buchite ejecta of Stromboli (Aeolian Islands, Italy), J .Petrol., 52, 541-564.

Del Moro, S., A. Renzulli, P. Landi, S. La Felice and M. Rosi (2013). Unusual lapilli tuff ejecta erupted at Stromboli during the 15 March 2007 explosion shed light on the nature and thermal state of rocks forming the crater system of the volcano, J. Volcanol. Geotherm. Res., 254, 37-52.

Di Bella, M., P. Mazzoleni, S. Russo, G. Sabatino, G. Tigano and A. Tripodo (2016). Archaeometric characterization of Roman volcanic millstones from Messina territory (Sicily, Italy). Periodico di Mineralogia, 85, 69-81.

Di Renzoni, A., M.C. Martinelli, L. Lopes and E. Photos-Jones (2016a). The relationship between early settlements in arid environments and sources of water supply: the case of the Bronze Age site of San Vincenzo, Stromboli, Italy. In Photos-Jones E. (editor), Proceedings of the 6th Symposium of the Hellenic Society for Archaeometry, British Archaeological Reports, 187-193.

Di Renzoni, A, G. Ayala, D. Brunelli, S.T. Levi, S. Lugli, E. Photos-Jones, A. Renzulli and P. Santi (2021b). Aiding and abetting the archaeological enquiry: geochemical work-in-progress at the site of San Vincenzo, Stromboli, Aeolian Islands, Italy. In Photos-Jones E. (editor), Proceedings of the 6th Symposium of the Hellenic Society for Archaeometry, British Archaeological Reports, 167-174.

Dibben, C.J.L. (2008). Leaving the city for the suburbs-The dominance of 'ordinary' decision making over volcanic risk perception in the production of volcanic risk on Mt Etna, Sicily, J. Volcanol. Geotherm. Res., 172, 288-299.

Douglas, M. and A. Wildavsky (1982). Risk and Culture: an Essay on the Selection of Technological and Environmental Dangers. University of California Press.

Edlund-Berry, I. (2006). Hot, cold, or smelly: The power of sacred water in Roman religion, 400-100 bce, in C. Schultz and P. Harvey (eds), Religion in Republican Italy, Yale Classical Studies, 162-180, doi:10.1017/CBO9780511482816.008.

Fazio, I. (2008). Parentela e mercato nell'isola di Stromboli (XIX secolo), in R. Ago, B. Borello (eds), Famiglie. Circolazione di beni, circuiti di affetti in età moderna, 123-163.

Fazio, I. (2012). Fraud, Conflict and Contraband in Sicilian Corsairing (Stromboli, 1811). Paper presented at Frauds: norms, institutions and illegal economic practices in Mediterranean Europe (16th-19th centuries), Universität 
Basel, 28-29 septembre 2012, 1-8.

Ferranti, F., M. Bettelli, V. Cannavò, A. Di Renzoni, S.T. Levi and M.C. Martinelli (2015). San Vincenzo - Stromboli (Lipari, Prov. Di Messina), Notiziario di Preistoria e Protostoria, 2.II, 56-62.

Forenbaher, S. (2018). Special Place, Interesting Times: The Island of Palagruža and Transitional Periods in Adriatic Prehistory. Oxford.

Francalanci, L., F. Lucchi, J. Keller, G. De Astis and C.A. Tranne (2013). Chapter 13, Eruptive, volcano-tectonic and magmatic history of the Stromboli volcano (north-eastern Aeolian archipelago), in F. Lucchi, A. Peccerillo, J. Keller, C. A. Tranne and P. L. Rossi (eds), The Aeolian Islands Volcanoes, Geological Society, London, Memoirs, 37, 397-471.

Freund, K.P. (2018). A long-term perspective on the exploitation of Lipari obsidian in central Mediterranean prehistory, Quaternary Inter., 469, 109-120.

Gaillard, J.-C. (2008). Alternative paradigms of volcanic risk perception: The case of Mt. Pinatubo in the Philippines, J. Volcanol. Geotherm. Res., 172, 315-328.

Gaillard, J.-C. and Dibben C.J.L. eds (2008). Volcanic risk perception and beyond, J. Volcanol. Geotherm. Res., Special Issue, 172, 163-340.

Giacomantonio, M. (2010). Navigando nella storia delle Isole Eolie, Marina di Patti, 136-507.

Gillot, P.Y. (1987). Histoire volcanique des Iles Eoliennes: arc insulaire ou complexe orogénique anulaire? Documents et Travaux, IGAL (Institut Ge'ologique Albert-de-Lapparent), Paris, 11, 35-42.

Gillot, P.-Y. and J. Keller (1993). Radiochronological dating of Stromboli, Acta Vulcanologica, 3, 69-77.

Giordano, G. and G. De Astis (2021). The summer 2019 basaltic Vulcanian eruptions (paroxysms) of Stromboli. Bull. Volcanol., 83, 1, https://doi.org/10.1007/s00445-020-01423-2

Gluhak, T.M. and C. Schwall (2015). Provenance analyses of the volcanic rock grinding stones from the Greek colony of Selinunte, Sicily (Italy)-constraints and possibilities, Archaeometry 57, 2, 246-268.

Griffith, A.B. (2015). Alternative Medicine in Pre-Roman and Republican Italy: Sacred Springs, Curative Baths and “Votive Religion”, Krötzl C., Mustakallio K., Kuuliala J. (eds.) Infirmity in Antiquity and the Middle Ages: Social and Cultural Approaches.

Harris, A. and M. Ripepe (2007). Synergy of multiple geophysical approaches to unravel explosive eruption conduits and source dynamics - a case study from Stromboli. Chemie der Erde, 67, 1-35.

Heimisdóttir, P., A.D. Sæpórsdóttir and G. Gísladóttir (2019). The sublime attraction of active volcanoes: An exploration of tourists' experiences during a longdistance hiking route in Iceland. Tourist Studies, Vol. 19(2) $258-275$.

Hewitt, K. editor (1983). Interpretations of Calamity From the Viewpoint of Human Ecology, London, 25.

Holton, G.A. (2004). Defining risk. Financial Analysts Journal, 60, 6, 19-25, doi:10.2469/faj.v60.n6.2669

Johnson, D.and S. Levin (2009). The tragedy of cognition, Current Science, 97, 11, 1593-1603.

Jones, R.E., S. T. Levi, M. Bettelli, L. Vagnetti (2014). Italo-Mycenaean Pottery: the Archaeological and Archaeometric Dimensions. Incunabula Graeca, CIII, Roma: CNR-ISMA.

Kahneman, P., Slovic P. and A. Tversky eds (1982). Judgement under uncertainity: Heuristic and biases, Cambridge.

Karakhanian, A., R. Djrbashian, V. Trifonov, H. Philip, S. Arakelian, A. Avagian (2002). Holocene-historical volcanism and active faults as natural risk factors for Armenia and adjacent countries, J. Volcanol. Geotherm. Res. 113, 319-344.

Kates, R.W. (1971). Natural Hazard in Human Ecological Perspective: Hypotheses and Models. Economic Geography, 47, 3, 438-451.

Keller J. (2002). Lipari's fiery past: dating the medieval pumice eruption of Monte Pelato. Internat. Conference UNESCO Regione Siciliana, Lipari, September 29-October 2, 2002.

Kępińska, B. (2004). Lectures on geothermal resources and utilization in Poland and Europe, Lectures on geothermal energy given in September 2003 United Nations University, Geothermal Training Programme Reykjavík, Iceland.

Kjarsgaard, I., J. Keller, U. Kobersky, E. Stadlbauer, L. Francalanci and R. Lenhart (1993). Geology, stratigraphy and volcanological evolution of the island of Stromboli, Aeolian Arc, Italy, Acta Vulcanologica, 3, 21-68.

Lavigne, F., B. De Coster, N. Juvin, F. Flohic, J.-C. Gaillard, P. Texier, J. Morin and J. Sartohadi (2008). People’s behaviour in the face of volcanic hazards: Perspectives from Javanese communities, Indonesia, J. Volcanol. Geotherm. Res., 172, 273-287. 


\section{Andrea Di Renzoni et al.}

Lentini, R. (2015). L' invasione silenziosa. Storia della fillossera nella Sicilia dell'800. Torri del Vento Edizioni.

Levi, S.T., M. Bettelli, V. Cannavò, A. Di Renzoni, F. Ferranti, M. C. Martinelli, V. Vertuani, L. Zaghetto (2020). Looking for Codes and Paths into the Capo Graziano Decoration (Untitled \#2), in J. Driessen A. Vanzetti (eds), Communication Uneven. Acceptance of and Resistance to Foreign Influences in the Connected Ancient Mediterranean, Aegis, 20, 17-38.

Levi, S.T., M. Bettelli, V. Cannavò, A. Di Renzoni, F. Ferranti, M.C. Martinelli, A. Ollà and G. Tigano (2017). Stromboli: gateway for the Mycenaean early connections through the Messina's Strait, in A. Vlachopoulos, Y. Lolos, R. Laffineur and M. Fotidias (eds) HESPEROS. The Aegean seen from the West. 16th International Aegean Conference (Ioannina 2016), Aegaeum, 41, 147-154. Liège: Peeters.

Lowrence, W.L. (1980). The nature of the risk, in R. C. Schwing, W. A. Albers Jr (eds), How Safe is Safe Enough?, 5 -17. Lucchi, F., A. Peccerillo, J. Keller J., C.A. Tranne, P.L. Rossi (eds) (2013a). The Aeolian Islands Volcanoes, Geological Society Memoir, 37, London.

Lucchi, F., J. Keller and C.A. Tranne (2013b). Regional stratigraphic correlations across the Aeolian archipelago (southern Italy), in Lucchi, F., A. Peccerillo, J. Keller J., C. A. Tranne, P. L. Rossi (eds). The Aeolian Islands Volcanoes, Geological Society Memoir, 37, London, 55-81.

Malaguti A.B., Rosi, M, Pistolesi M., Speranza F., Menzies M. (2021). The contribution of palaeomagnetism, tephrochronology and radiocarbon dating to refine the last 1100 years of eruptive activity at Vulcano (Italy). Bulletin of Volcanology. doi:10.1007/s00445-021-01515-7.

Mammana, A. (2006). Le sorgenti delle Isole Eolie, Messina, 25-81.

Manni, M., M. Coltelli and M.C. Martinelli (2019). Volcanic events that Have marked the anthropic history of the Aeolian Islands, Ann. Geophys., 62, 1, VO08, 1-16.

Manni, M. and M. Rosi (2021). Origins of Vulcanello based on the re-examination of historical sources (Vulcano, Aeolian Islands). In: When volcanologists meet archaeologists and other disciplines: relationships between eruptions and human communities. Special Volume, Ann. Geophys., 64, 5, doi:10.4401/ag-8670, this issue.

Marazzi, M. (2016). Connessioni transmarine: Vivara e Pantelleria, dinamiche e cronologie dei più antichi contatti con le aree egee e levantine, Scienze dell'Antichità, 22, 2, 131-147.

Martinelli, M.C. (2005). Il villaggio dell'età del bronzo medio di Portella a Salina nelle isole Eolie. Ist. Italiano di Preistoria, Firenze.

Martinelli, M.C. (2011), Archeologia delle isole Eolie. Il villaggio dell'età del bronzo medio di Portella a Salina, Ricerche 2006 e 2008. Rebus Edizioni.

Martinelli, M.C. (2015). Vulcanologia, sezione uomo ambiente, Guide del Museo Regionale "Luigi Bernabò Brea", Palermo.

Martinelli, M.C. and M.A. Mastelloni (2015). Il museo Archeologico, Guida al Museo Archeologico Regionale "Luigi Bernabò Brea" - Lipari, Palermo.

Martinelli, M.C., R. Tykot and A. Vianello (2019). Lipari (Aeolian Islands) Obsidian in the Late Neolithic. Artifacts, Supply and Function, Open Archaeology, 5, 1, 46-64.

Martinelli, M.C., E. Dawson, P. Lo Cascio, S.T. Levi and G. Fiorentino (2021). Blowin' in the wind: settlement and landscape dynamics in the prehistory of the Aeolian Islands (Italy). J. Med. Archaeology, 34,1, 28-57.

Martinelli, M.C., M. Coltelli, M. Manni, L. Bonizzoni, A. Guglielmetti, M. Oddone and M. L. Balestrieri (2020). Prehistorical Obsidian Sources in the Island of Lipari (Aeolian Islands), Open Archaeology, 6, 393-402. https://doi.org/10.1515/opar-2020-0119.

Meliksetian, K. (2013). Pliocene-Quaternary volcanism of the Syunik upland (Armenia), in H. Meller and P. Avetisyan (eds), Archaeology in Armenia, II Edition, 248-258.

Métrich, N., A. Bertagnini, P. Landi, M. Rosi (2001). Crystallization driven by decompression and water loss at Stromboli volcano (Aeolian Islands, Italy), J. Petrol., 42, 1471-1490.

Mosconi, G. (2002). Aetna 435: "sulphure non solum sed obesa et alumine terra est?" (a proposito dell'allume delle Lipari). Rivista di cultura classica e medioevale, 44, 2, 337-355. doi: https://www.jstor.org/stable/23961085

Nisbet, R. and L. Ross (1980). Human Inference: Strategies and Shortcomings of Social Judgment. Englewood Cliffs, NJ.

Nomade, S., D. Genty, R. Sasco, V. Scao, V. Féruglio, D. Baffier, H. Guillou, C. Bourdier, H. Valladas, E. Reigner, E. Debard, J.-F. Pastre and J.-M. Geneste (2016). A 36,000-Year-Old Volcanic Eruption Depicted in the ChauvetPont d'Arc Cave (Ardèche, France)?, PLoS ONE, 11,1, e0146621. doi:10.1371/journal.pone.0146621 
Norenzayan, A., I.G. Hansen and J. Cady J.2008. An angry volcano? Reminders of death and anthropomorphizing nature, Social Cognition, 26, 2, 190-197.

Pacciarelli, M. (2011). L'Eneolitico della Calabria tirrenica: nuovi dati sull'articolazione cronoculturale. Origini, XXXIII, NS V, 249-302.

Panton, D., L. Smith, M. Daly, D. Johnston (2008). Risk perception and volcanic hazard mitigation: Individual and social perspectives, J. Volcanol. Geotherm. Res., 172, 179-188.

Perry, R.W. and M.K. Lindell (2008). Volcanic risk perception and adjustment in a multi-hazard environment, J. Volcanol. Geotherm. Res., 172, 170-178.

Photos-Jones, E. and A. Hall (2014). Eros, Mercator, and the cultural landscape of Melos in antiquity, Glasgow.

Photos-Jones, E. and R. Jones (2018). Mycenaean 'Alum': Implications for the Exchange of Astringent Minerals in the Bronze Age, in M. Bettelli and M. Del Freo (eds), Mediterranea Itinera Studies in Honour of Lucia Vagnetti, Incunabula Graeca, CVI, Roma.

Photos-Jones, E., B. Barrett and G. Christidis (2017). Stevenson at Vulcano in the late 19th century: a Scottish mining venture in southern Europe. Proc Soc Antiq Scot, 147, 303-323. https://doi.org/10.9750/PSAS.147.1255

Pistolesi, M., D. Delle Donne, L. Pioli, M. Rosi and M. Ripepe (2011). The 15 March 2007 explosive crisis at Stromboli volcano, Italy: assessing physical parameters through a multidisciplinary approach, J. Geophys. Res., 116, http://dx.doi.org/10.1029/2011JB008527.

Pistolesi, M., A., Bertagnini, A. Di Roberto, M. Ripepe, M. Rosi (2020). Tsunami and tephra deposits record interactions between past eruptive activity and landslides at Stromboli volcano, Italy. Geology, 48 (5), 436-440.

Pistolesi, M., M. Rosi, A.B. Malaguti, F. Lucchi, C.A. Tranne, F. Speranza, P.G. Albert, V.C. Smith, A. Di Roberto, E. Billotta (2021). Chrono-stratigraphy of the youngest (last 1500 years) rhyolitic eruptions of Lipari (Aeolian Islands, Southern Italy) and implications for distal tephra correlations. Journal of Volcanology and Geothermal Research 420 (2021) 107397.

Pittinger, J. (1975). The Mineral Products of Melos in Antiquity and their Identification. The Annual of the British School at Athens, 70, 191-197. doi:10.1017/S0068245400006614

Pitto, C. (1990). Le metamorfosi di un'isola Continuità e conflitto a Stromboli. La Ricerca Folklorica, 21, La cultura del mare, 69-74.

Renzulli, A. and P. Santi (1997). Sub-volcanic crystallization at Stromboli (Aeolian Islands, Southern Italy) preceding the Sciara del Fuoco sector collapse: evidence from monzonite lithic suite, Bull. Volcanol., 59, 10-20.

Renzulli, A., P. Santi, T. Gambin and P.B. Serrano (2019). Pantelleria Island as a centre of production for the Archaic Phoenician trade in basaltic millstones: New evidence recovered and sampled from a shipwreck off Gozo (Malta) and a terrestrial site at Cádiz (Spain). J. Archaeological Sci.: Reports, 24, 338-349.

Renzulli, A., S. Del Moro, M. Menna, P. Landi and M. Piermattei (2009). Transient processes in Stromboli’s shallow basaltic system inferred from dolerite and magmatic breccias blocks erupted during the 5 April 2003 paroxysm, Bull. Volcanoll., 71. http://dx.doi.org/10.1007/s00445-009-0265-y.

Renzulli, A., M. Taussi, F.J. Brink, S. Del Moro and R.W. Henley (2021). Sulphide Globules in a Porcellanite-Buchite Composite Xenolith from Stromboli Volcano (Aeolian Islands, Southern Italy): Products of Open-System Igneous Pyrometamorphism. Minerals, 11, 639. https://doi.org/10.3390/min11060639.

Risica, G., F. Speranza, G. Giordano, G. De Astis and F. Lucchi F. (2019). Palaeomagnetic dating of the Neostromboli succession, J. Volcanol. Geotherm. Res., 371, 229-244

Romagnoli, C., D. Casalbore et al. (2013). Bathy-morphological setting of the Aeolian Islands, in F. Lucchi, A. Peccerillo, J. Keller, C. A. Tranne and P. L. Rossi, P. L. (eds), The Aeolian Islands Volcanoes. Geological Society, London, Memoirs, 37, 27-36.

Rosi, M, A. Bertagnini, A.J.L. Harris, L. Pioli, M. Pistolesi M. Ripepe (2006). A case history of paroxysmal explosions at Stromboli: timing and dynamics of the April 5, 2003 event, Earth Planet. Sci Lett, 243, 594-606.

Rosi, M., A. Bertagnini and P. Landi (2000). Onset of the persistent activity at Stromboli volcano (Italy), Bull. Volcano., 62, 294-300.

Rosi, M., S.T. Levi, M. Pistolesi, A. Bertagnini, D. Brunelli, V. Cannavò, A. Di Renzoni, F. Ferranti, A. Renzulli and D. Yoon (2019). Geoarchaeological Evidence of Middle-Age Tsunamis at Stromboli and Consequences for the Tsunami Hazard in the Southern Tyrrhenian Sea, Scientific Reports, 9, 677, doi:10.1038/s41598-018-37050-3.

Samuelson, W. and R. Zeckhauser (1988). Status Quo Bias in Decision Making, J. Risk Uncertainity, 1, 7-59.

Santi, P., A. Renzulli A. and M. Bell (2015). The volcanic millstones from the archaeological site of Morgantina 


\section{Andrea Di Renzoni et al.}

(Sicily): Provenance and evolution of the milling techniques in the Mediterranean area, Archaeometry, 57, 803-821

Santi, P., A. Renzulli and R. Gullo (2013). Archaeometric study of the hopper-rubber and rotary Morgantina-type volcanic millstones of the Greek and Roman periods found in the Aeolian Archipelago (Southern Italy), Eur. J. Mineral., 25, 39-52.

Santi, P., F. Foresta Martin, F. Spatafora, S. de Vita S. and Renzulli A. (2020). Volcanic Grinding Tools in Ustica Island (Tyrrhenian Sea, Italy): Local Production vs. Import of Morgantina-Type Millstones in the Hellenistic- Roman Period, Minerals, 10, 389.

Santi, P., Gambin, T. and Renzulli, A. (2021). The millstones trade from the most exploited Italian volcanic areas: an overview from the phoenicians to the roman period. In: When volcanologists meet archaeologists and other disciplines: relationships between eruptions and human communities. Special Volume, Ann. Geophys., 64, 5 , doi:10.4401/ag-8647, this issue.

Scheidel, W. (ed) (2012). The Cambridge Companion to the Roman Economy (Cambridge Companions to the Ancient World, 131-132). Cambridge: Cambridge University Press.

Schlehe, J. (1996). Reinterpretations of Mystical Traditions Explanations of a Volcanic Eruption in Java, Anthropos, 91, 391-409.

Schmitt, A.K., M. Danišik, E. Aydar, E. Şen, I. Ulusoy and O.M. Lovera (2014). Identifying the Volcanic Eruption Depicted in a Neolithic Painting at Çatalhöyük, Central Anatolia, Turkey, PLoS ONE, 9,1, e84711, doi:10.1371/journal.pone.0084711.

Short, J. Jr (1984). The Social Fabric at Risk: Toward the Social Transformation of Risk Analysis. Am. Sociol. Rev., 49, 6, 711-725.

Sigurdsson, H. and R. Lopes-Gautier (2007). Volcanoes and Tourism, in H. Sigurdsson (ed) Encyclopedia of Volcanoes, 1283-1299.

Simon, H.A. (1959). Theories of decision making in economics and behavioral science, Am. Economic Rev., 49, $253-$ 283.

Slovic, P. (1987). Perception of the Risk. Science, 236, 236-285.

Slovic, P. (editor) (2000). The Perception of Risk, Routledge, New York.

Slovic, P., H. Kunreuther and G.F. White (2000). Decision Processes, Rationality and Adjustment to Natural Hazards, in P. Slovic (editor) The Perception of the Risk, Routledge, New York.

Speranza, F., M. Pompilio, F. D’Ajello Caracciolo and L. Sagnotti (2008). Holocene eruptive history of the Stromboli volcano: constraints from paleomagnetic dating, J. Geophys. Res., 113, B09101.

Starr, C. (1969). Social Benefits versus Technological Risk. What is our society willing to pay for safety?, Science, 165, 1232-1238.

Steinhauser, G., M. Bichler, G. Eigelsreiter and A. Tischner A. (2006). Neutron activation analysis of pumice from Lipari, Italy, and the identification of a pumice find from the excavation at Tel Megadim, Israel, J. Radioan.l Nuclear Chem., 267, 1, 3 - 8.

Sterba, J.H., K. Polinger Foster, G. Steinhauser and M. Bichler (2009). New light on old pumice: the origins of Mediterranean volcanic material from ancient Egypt, J. Archaeological Sci., 36, 1738-1744.

Sword-Daniels, V., T. Wilson, S. Sargeant, T. Rossetto, J. Twigg, D. M. Johnston, S.C. Loughlin and P.D. Cole (2014). Chapter 26 Consequences of long-term volcanic activity for essential services in Montserrat: challenges, adaptations and resilience. The Eruption of Soufrière Hills Volcano, Montserrat from 2000 to 2010, Geological Society, London, Memoirs, 39, 471-488.

Swanson, D. A. (2008). Hawaiian oral tradition describes 400 years of volcanic activity at Kỉlauea, J. Volcanol. Geotherm. Res., 176, 3, 427-431.

Tanguy, J.C., M. Le Goff, C. Principe, S. Arrighi, V. Chillemi, A. Paiotti, S. La Delfa and G. Patanè (2003). Archeomagnetic dating of Mediterranean volcanics of the last 2100 years: validity and limits, Earth Planet. Sci. Letters, 211, 1-2, 111-124.

Tarquini, S., I. Isola, M. Favalli, F. Mazzarini, M. Bisson, M.T. Pareschi and E. Boschi (2007), TINITALY/01: a new Triangular Irregular Network of Italy, Ann. Geophys., 50, 407-425.

Tibaldi, A. (2001). Multiple sector collapses at Stromboli volcano: how they work, Bull. Volcanol., 63, 112-125.

Tinti S., F. Pagnoni, F. Zaniboni and E. Bortolucci (2003). Tsunami generation in Stromboli island and impact on the south-east Tyrrhenian coasts, Nat. Hazards Earth Sys. Sci., 3, 299-309. 
Tranne, C.A., Lucchi, F., Calanchi, N., Lanzafame, G., Rossi, P.L. (2002): Geological map of the island of Lipari (Aeolian Islands). Università di Bologna and INGV, L.A.C. Firenze, Italy.

Tykot, R. (2019). Geological Sources of Obsidian on Lipari and Artifact Production and Distribution in the Neolithic and Bronze Age Central Mediterranean, Open Archaeology, 5, 1, 83-105.

Ulusoy, I., M. Akif Sarıkaya, A.K. Schmitt, M. Şen E. Danisiik and E. Gümüş (2019). Volcanic eruption eye-witnessed and recorded by prehistoric humans, Quaternary Sci. Rev., 212, 187-198.

Vezzoli, L., A. Renzulli, and M. Menna (2014). Growth after collapse: The volcanic and magmatic history of the Neostromboli lava cone (island of Stromboli, Italy), Bull. Volcanol., 76, 821, doi:10.1007/ s00445-014-0821-y.

Vidale, M., S.T. Levi, M. Bettelli, A. Di Renzoni, M. Bettuzzi, V. Cannavò V., F. Casali, F. Ferranti, L. Lopes, M.P. Morigi, C. Triolo, M. Triolo (2018). Eating Molluscs at Stromboli (Aeolian Islands, Italy), 1700 BC. Studi Micenei ed Egeo-Anatolici, 4 NS, 161-190.

Wagner, G.A., Storzer, C. \& Keller, J. (1976). Spaltspurendatierung quartärer Gesteinsgla"ser aus dem Mittelmeerraum. Neues Jahrbuch für Mineralogie Monatshefte, 2, 84-94.

Williams-Thorpe, O. and R.S. Thorpe (1990). Millstone provenancing used in tracing the route of a fourth-century BC Greek merchant ship, Archaeometry, 32, 115-137.

Zanchetta, G., R. Sulpizio, N. Roberts, R. Cioni, W.J. Eastwood, G. Siani, B. Caron, M. Paterne, and R. Santacroce (2011). Tephrostratigraphy, chronology and climatic events of the Mediterranean basin during the Holocene: An overview, The Holocene, 21, 1, 33-52. 